Keitty Raquel Benevides Pereira

Estudo dos mecanismos imunológicos envolvidos na recrudescência da malária experimental durante a gravidez

Dissertação apresentada ao Programa de Pós graduação em Biologia da Relação Patógeno Hospedeiro do Instituto de Ciências Biomédicas da Universidade de São Paulo, para obtenção do título de Mestre em Ciências 
Keitty Raquel Benevides Pereira

\section{Estudo dos mecanismos imunológicos envolvidos na recrudescência da malária experimental durante a gravidez}

Dissertação apresentada ao Programa de Pós graduação em Biologia da Relação Patógeno Hospedeiro do Instituto de Ciências Biomédicas da Universidade de São Paulo, para obtenção do título de Mestre em Ciências

Área de concentração: Biologia da Relação Patógeno Hospedeiro

Orientador: Prof. Dr. Cláudio Romero Farias Marinho

Versão original 
DADOS DE CATALOGAÇÃO NA PUBLICAÇÃO (CIP)

Serviço de Biblioteca e Informação Biomédica do

Instituto de Ciências Biomédicas da Universidade de São Paulo

reprodução não autorizada pelo autor

Pereira, Keitty Raquel Benevides.

Estudo dos mecanismos imunológicos envolvidos na recrudescência da malária experimental durante a gravidez / Keitty Raquel Benevides Pereira. -- São Paulo, 2012.

Orientador: Prof. Dr. Claudio Romero Farias Marinho.

Dissertação (Mestrado) - Universidade de São Paulo. Instituto de Ciências Biomédicas. Departamento de Parasitologia. Área de concentração: Biologia da Relação Patógeno-Hospedeiro. Linha de pesquisa: Imunopatologia da malária associada à gravidez

Versão do título para o inglês: Study of immunologic mechanisms involved in the recrudescence of experimental malaria during pregnancy.

1. Gravidez 2. Malária 3. Plasmodium berghei 4. Recrudescência 5.Placenta 6. Imunologia I. Marinho, Prof. Dr. Claudio Romero Farias II. Universidade de São Paulo. Instituto de Ciências Biomédicas. Programa de Pós-Biologia da Relação Patógeno-Hospedeiro III. Título. 
Candidato(a):

Título da Dissertação:

Orientador(a):
Keitty Raquel Benevides Pereira.

Estudo dos mecanismos imunológicos envolvidos na recrudescência da malária experimental durante a gravidez.

A Comissão Julgadora dos trabalhos de Defesa da Dissertação de Mestrado, em sessão pública realizada a I... I.

\section{( ) Aprovado(a) ( ) Reprovado(a)}

Examinador(a): Assinatura:

Nome:

Instituição:

Examinador(a): Assinatura:

Nome:

Instituição:

Presidente: Assinatura:

Nome:

Instituição: 


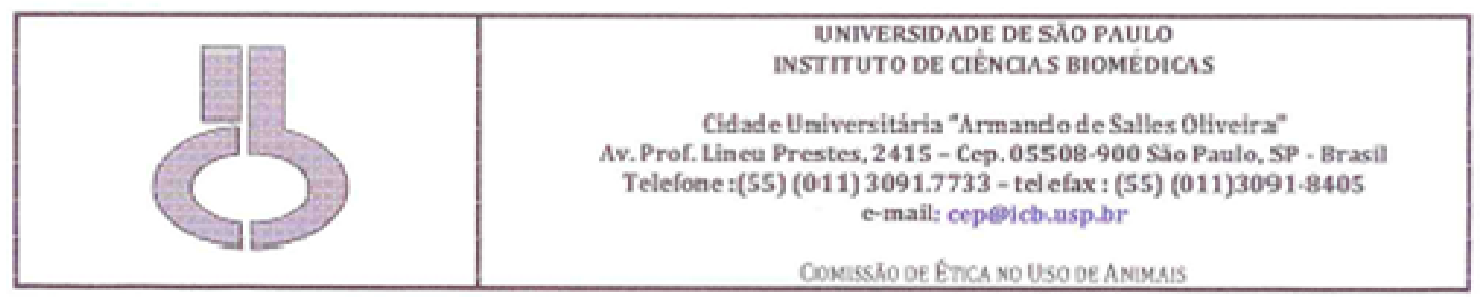

Decl. CEUA.017/2010

D E C L A R A Ç Ã O

Em adendo ao Certificado 15/10/CEUA, datado de 08.03.10 e por solicitação do Prof. Dr. Claudio Romero Farias Marinho, responsável pela linha de Pesquisa, autorizo a inclusão da aluna Keitty Raquel Benevides Pereira ao Projeto de Pesquisa "Estudo dos mecanismos imunopatologicos envolvidos na malária associada à gravidez", uma vez que se trata de utilização da mesma espécie animal e de métodos experimentais similares ao referido certificado.

São Paulo, 12 de abril de 2010.

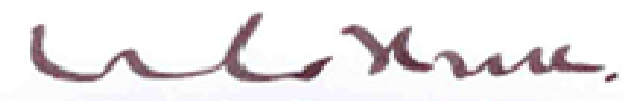

Prof. Dr. Wothan Tavares de Lima

Coordenador da CEUA

ICB/USP 


\section{AGRADECIMENTOS}

Agradeço primeiramente a DEUS pela minha vida, por ter me iluminado em toda minha caminhada e por não me deixar desistir em frente às dificuldades. "Pai, meu Pai do céu, eu quase me esqueci, me esqueci que o seu amor vela por mim".

A minha família, por ser meu porto seguro, pelo amor, compreensão e dedicação o tempo todo: Papai, Mamãe, por me fazerem ser o que eu sou, e minhas irmãs Kalinka e Karen, por me ajudarem a seguir a caminhada um tanto quanto conturbada. Aos meus sobrinhos, Luigi e Laurinha, que apesar de pequeninos são muito importantes e são o motivo da minha alegria.

Ao meu orientador Cláudio Marinho, pela credibilidade depositada em mim para realização deste trabalho, pelos ensinamentos e por me fazer acreditar que posso ser melhor a cada dia.

Aos professores colaboradores desse trabalho, José Maria Alvarez Mosig, Maria Regina D’Império Lima, Ana Paula Lepique e Sabrina Epiphanio pelo suporte nos experimentos.

Aos professores Beatriz Stolf, Estela Bevilacqua e Marcelo Urbano, que estiveram presentes na banca de qualificação e puderam contribuir da melhor forma para o desfecho deste trabalho.

A Claudia Zago, por todo ensinamento da técnica de citometria de fluxo.

Aos amigos do laboratório: Leandro Silva, Rodrigo Medeiros, Renato Barboza pelos momentos de aprendizagem, de companheirismo, de descontração, permitindo que eu seguisse adiante mesmo quando isso era difícil. Ao Renato queria agradecer também por toda força e apoio no congresso SBI durante a apresentação oral do meu trabalho. E não me esquecendo da Vanessa, que mesmo convivendo por menos tempo, foi muito importante nos desabafos e nos momentos de alegria. 
Ao Eduardo Pinheiro Amaral, pela amizade desde a graduação na UENF e que foi a ponte para que eu pudesse chegar a USP e trabalhar na área que eu sempre desejei.

As amigas Luana Ortolan e Michelle Klein, alunas da Prof. ${ }^{a}$ Sabrina, pelo apoio e pelos momentos vividos ao longo desses dois anos.

Aos amigos da imunologia, Giovana Giacomini, Beatriz Villas Boas, Christian Jorquera por estarem presentes em momentos decisivos e em momentos fora da USP, onde foi possível aliviar o estresse. Em especial ao Rafael Salgado, que desde o início esteve comigo me auxiliando nos experimentos, me divertindo com seu jeito e dividindo histórias, fazendo com que meus dias fossem menos pesados.

Aos amigos da parasitologia, Maurício Scavassini, Mariana Galuppo, Wesley Fotoran.

A Fundação de Amparo à Pesquisa do Estado de São Paulo (FAPESP) pelo suporte financeiro.

Enfim, agradeço a todos que de alguma forma contribuíram para realização e conclusão deste trabalho. OBRIGADA! 
Tudo, aliás, é a ponta de um mistério, inclusive os fatos. Ou a ausência deles.

Duvida? Quando nada acontece há um milagre que não estamos vendo.

(Guimarães Rosa)

Quero conhecer os pensamentos de Deus, o resto é detalhe.

(Albert Einstein) 
RESUMO 
PEREIRA, K.R.B. Estudo dos mecanismos imunológicos envolvidos na recrudescência da malária experimental durante a gravidez. 2012. $105 \mathrm{f}$., [Dissertação (Mestrado em Biologia da Relação Patógeno Hospedeiro)] - Instituto de Ciências Biomédicas, Universidade de São Paulo, São Paulo, 2012.

Estima-se que mais de 50 milhões de gestações ocorram, por ano, em áreas endêmicas de malária. Mulheres que vivem em áreas com alta endemicidade apresentam menos sintomas da malária durante a gravidez e os efeitos mais graves da doença estão relacionados com a primeira e segunda gestação. Neste trabalho, usamos um modelo murino de recrudescência da malária associada à gravidez, com camundongos BALB/c infectados por Plasmodium berghei ANKA ${ }^{\text {GFP }}$ com o objetivo de avaliar a resposta imune associada ao recrudescimento da infecção. $A$ análise morfométrica da placenta mostrou que as fêmeas primíparas recrudescentes apresentaram uma redução no espaço vascular placentário, quando comparado com primíparas não infectadas e não recrudescentes (Média $\pm S D$ 38, $6 \pm 3,4,52,6 \pm 4,35$ e $44,8 \pm 4,64 \%$ de redução do espaço vascular, respectivamente). Observando as populações de células do baço por citometria de fluxo notou-se um aumento no percentual de células $\mathrm{CD} 4^{+}, \mathrm{CD} 19^{+}$, TCR $\gamma \delta^{+}, \mathrm{GR} 1^{+}$nos animais infectados, em relação aos controles não infectados. Não foram observadas diferenças no percentual de leucócitos placentários. Além disso, nossos resultados mostraram que no baço, linfócitos $\mathrm{TCD}^{+}$e TCD8 ${ }^{+}$estão mais ativados (representado pela maior expressão de CD69 e menor expressão de CD62L) em fêmeas recrudescentes. A análise do perfil de ativação de leucócitos placentários mostrou que os animais recrudescentes apresentaram um aumento na ativação de células TCD4 ${ }^{+}$. Em relação a resposta humoral, observou-se uma diferença significativa entre os níveis de IgM especifica de animais recrudescentes e não recrudescentes, além disso não foram observadas diferenças nos níveis de lgG1 e lgG2a. No entanto, a relação IgG2a/lgG1 em animais recrudescentes e não recrudescentes indicou um aumento de 3 vezes na produção de IgG2a que indica um padrão Th1 de resposta imune. A análise de qRT-PCR concomitantemente à citometria de fluxo evidenciou que células dendríticas são os reservatórios do parasita durante o estágio crônico da doença, que antecede o recrudescimento. Juntos, esses dados sugerem que a recrudescência durante a gestação está diretamente ligada ao dano tecidual, provavelmente relacionado a uma exacerbada resposta Th1 na placenta.

Palavras chave: Malária. Gravidez. Recrudescência. Placenta. P. berghei. 
PEREIRA, K.R.B. Study of the immunologic mechanisms involved in the recrudescence of experimental malaria during pregnancy. 2012. $105 \mathrm{f}$., [Master Thesis (Biology of Host-Pathogen Relationship)] - Instituto de Ciências Biomédicas, Universidade de São Paulo, São Paulo, 2012.

It is estimated that more than 50 million pregnancies every year occur in malaria endemic areas. Women living in areas with high malaria endemicity have fewer symptoms of malaria during pregnancy and severe disease is predominantly related to the first and second pregnancy. In this work, we used a murine model of recrudescence of malaria associated with pregnancy, consisting of BALB / c mice infected with Plasmodium berghei ANKAGFP to evaluate the immune response associated with the recrudescence of the disease. Morphometric analysis showed that placental recrudescent primiparous showed a reduction in placental vascular space, as compared to uninfected or non-primiparous recrudescent mice (38.6 \pm 3.4 , $52.6 \pm 4.35$ and $44.8 \pm 464 \%$ reduction in the vascular space, respectively). Observing the spleen cell populations by flow cytometry, an increase in the percentage of $\mathrm{CD}^{+}, \mathrm{CD} 19^{+}, \mathrm{TCR} \gamma \delta^{+}, \mathrm{GR} 1^{+}$cells was observed in the infected animals, compared to the uninfected controls. No differences were observed in the percentage of placental leukocytes. Furthermore, our results showed that in the spleen, $\mathrm{CD} 4^{+}$and $\mathrm{CD} 8^{+}$cells were in a more active state (represented by higher expression of CD69 and lower expression of CD62L) in recrudescent females. The profile analysis of placental leukocyte activation showed that recrudescent animals exhibited an increase in CD4 $+\mathrm{T}$ cell activation. With regards to the humoral immunity, there was a significant difference between the levels of specific $\operatorname{lgM}$ between the recrudescent and non-recrudescent animals. No differences were observed in the levels of IgG1 and IgG2a. However, the ratio IgG2a/lgG1 in recrudescent vs non-recrudescent animals showed a 3 -fold increase in the production of IgG2a indicating a Th1 immune response. qRT-PCR analysis, together with flow cytometry, showed that dendritic cells were the reservoirs of the parasite during the chronic stage of the disease, preceding the recrudescence. Together, these data suggest that recrudescence during pregnancy is directly linked to tissue damage, probably related to an exacerbated Th1 response in the placenta.

Keywords: Malaria. Pregnancy. Recrudescence. Placenta. P. berghei. 
Figura 1- Áreas de risco de transmissão por malária

Figura 2- Áreas de risco de infecção por malária 28

Figura 3- Casos no Brasil, divididos por espécies 30

Figura 4- Ciclo biológico do plasmódio 32

Figura 5- Sequestro de eritrócitos parasitados na placenta 36

Figura 6- Protocolo experimental com uso de parasitas GFP 47

Figura 7- Padronização do inóculo utilizado 57

Figura 8- Recrudescência da malária associada à gravidez 58

Figura 9- Redução do espaço vascular em gestantes com recrudescência. 60

Figura 10- Peso do baço e número total de células 61

Figura 11- Análise por citometria de fluxo do número de células esplênicas. 63

Figura 12- Análise de marcadores de ativação no baço por citometria de fluxo. 64

Figura 13- Peso da placenta e número total de células 65

Figura 14- Análise por citometria de fluxo do número de células placentárias 66

Figura 15- Análise de marcadores de ativação na placenta por citometria de fluxo. 
Figura 16- Quantificação de citocinas séricas Th1/Th2/Th17.

Figura 17- Determinação de anticorpos específicos para Plasmodium berghei

Figura 18- Curva de parasitemia e determinação de anticorpos específicos para Plasmodium berghei em animais desafiados 72

Figura 19- Recrudescência da malária durante a gestação. 73

Figura 20- Quantificação da carga parasitária por PCR em tempo real em diferentes tecidos. 75

Figura 21- Representação esquemática da esplenectomia 76

Figura 22- Localização do $P$. berghei em células dendríticas de baço e pulmão 78

Figura 23- Separação de células para localização do plasmódio 80 
Tabela 1- Anticorpos fluorescentes utilizados na análise por citometria de fluxo

Tabela 2- Presença de $P$. berghei em diferentes tecidos............................... 75

Tabela 3- Picos de parasitemia periférica e sua relação com a recrudescência

Tabela 4- Presença do parasita em células dendríticas do baço e pulmão...78 


\begin{tabular}{|c|c|}
\hline BSA & Bovine serum albumin \\
\hline CBA & Cytometric Bead Array \\
\hline CD & Cluster of Differentiation \\
\hline cDNA & Ácidos Desoxirribonucleico Complementar \\
\hline COBEA & Comissão Brasileira de Experimentação Animal \\
\hline $\mathrm{CO} 2$ & Dióxido de Carbono \\
\hline ELISA & Enzyme-Linked Immunoabsorbent Assay \\
\hline EP & Eritrócitos Parasitados \\
\hline FACS & Flow Acquisition Cell Sorter \\
\hline GAPDH & Glyceraldehyde-3-Phosphate Dehydrogenase \\
\hline GFP & Green Fluorescent Protein \\
\hline $\mathrm{H} \& \mathrm{E}$ & Hematoxilina e Eosina \\
\hline $\lg G$ & Imunoglobulina G \\
\hline IFN- $\gamma$ & Interferon Gamma \\
\hline IL & Interleucina \\
\hline i.p. & Via Intraperitoneal \\
\hline IPA & Incidência Parasitária Anual \\
\hline MCP-1 & Monocyte Chemotactic Protein 1 \\
\hline $\mathrm{N}_{2}$ & Nitrogênio \\
\hline $\mathrm{NaHCO}_{3}$ & Bicarbonato de Sódio \\
\hline $\mathrm{NH}_{4} \mathrm{Cl}$ & Cloreto de Amônio \\
\hline PAM & Pregnancy Associated Malaria \\
\hline PfEMP1 & Plasmodium falciparum Erythrocyte Membrane Protein 1 \\
\hline p.i. & Pós Infecção \\
\hline PM & Placental Malaria \\
\hline qRT-PCR & quantitative Reverse Transcription PCR \\
\hline RNA & Ácido Ribonucleico \\
\hline RPMI & Roswell Park Memorial Institute Medium \\
\hline SFB & Soro Fetal Bovino \\
\hline Th & T helper \\
\hline TMB & 3,3',5,5'-tetramethylbenzidine \\
\hline TNF & Tumor Necrosis Factor \\
\hline WHO & World Health Organization \\
\hline
\end{tabular}


1 INTRODUÇÃO .......................................................................................................................................................... 23

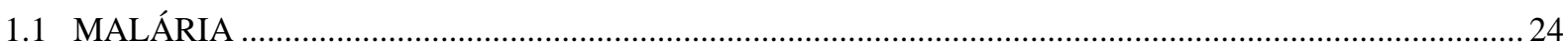

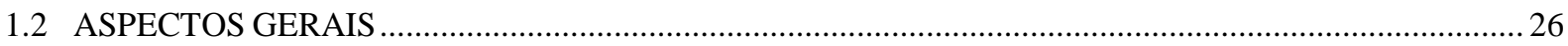

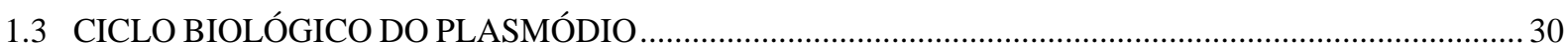

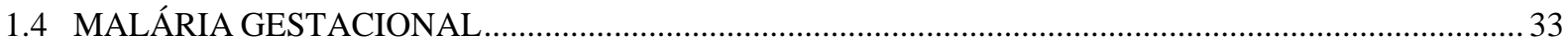

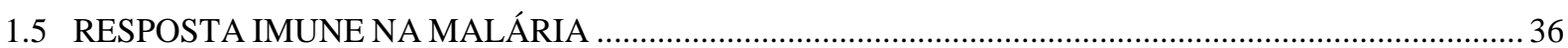

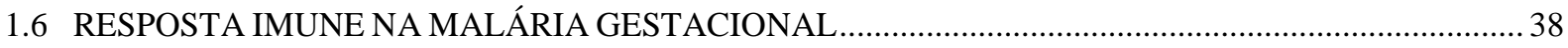

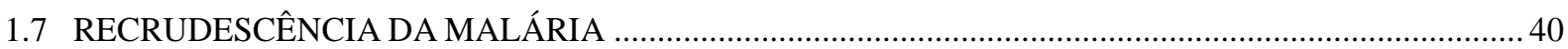

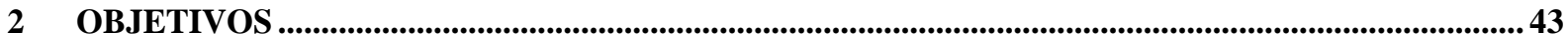

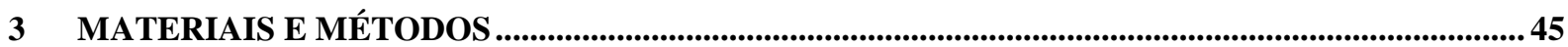

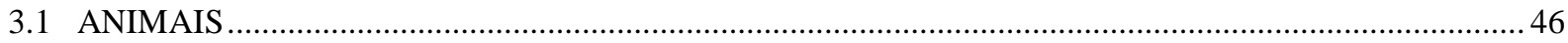

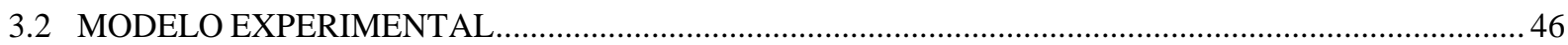

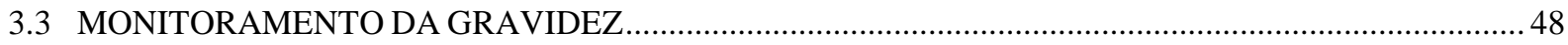

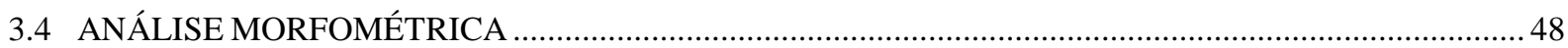

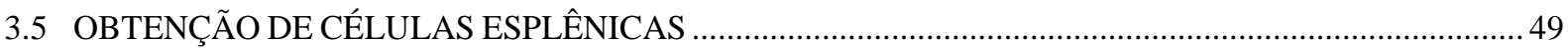

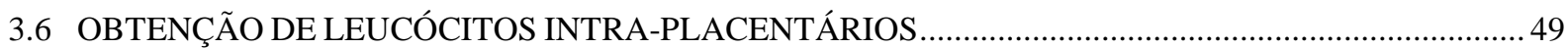

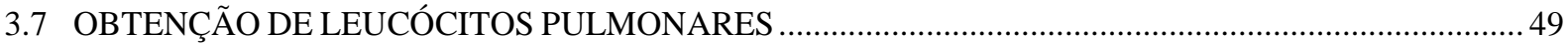

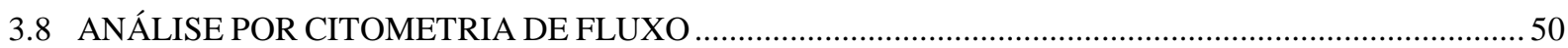

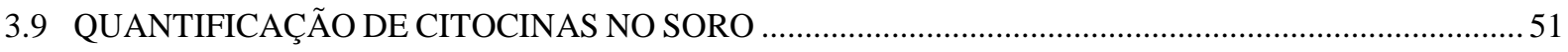

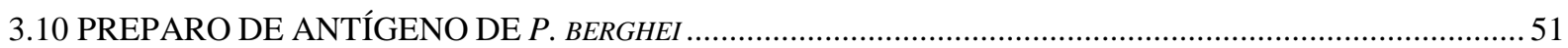

3.11 DETERMINAÇÃO DE ANTICORPOS IGM, IGG1 E IGG2A PARA P. BERGHEI ........................................52

3.12 EXPRESS ÃO GÊNICA ESPECÍFICA POR MEIO DE QRT-PCR ................................................................ 53

3.13 SEPARAÇÃO DE CÉLULAS (FACS ARIA CELL SORTER ${ }^{\circledR}$ ) ……………………................................... 53

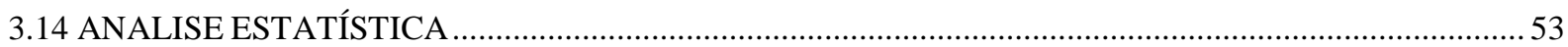

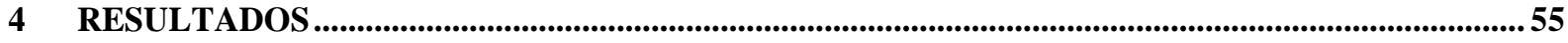

5 DISCUSSÃO

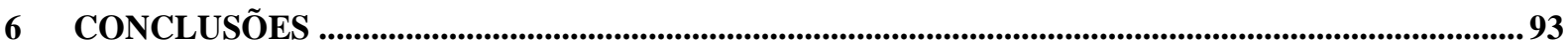

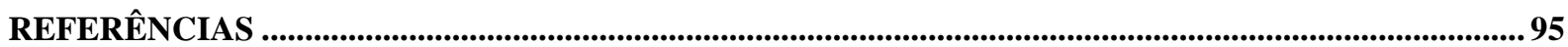




\subsection{MALÁRIA}

A malária é uma doença antiga, cujos registros mais remotos, como documentos chineses, tábuas de argila da Mesopotamia e papiros egípcios datam de 2000-1500 aC. No entanto, esta doença só foi realmente descrita em 400 aC, pelo grego Hipócrates. Por mais de 2.500 anos, acreditou-se que as febres associadas à malária eram causadas por vapores venenosos oriundos de pântanos, teoria do "mau ar" ou "male aria" em italiano, daí o nome malária ser atribuído à doença (COX, 2010). Somente após a descoberta das bactérias por Leeuwenhoek em 1767 e, cem anos depois, em 1878, após Louis Pasteur e Robert Koch postularem a "Teoria do germe", que dizia que microorganismos seriam causadores de doenças infecciosas, é que se começou a investigação sobre as possíveis causas da malária (COX, 2010).

Foi por volta de 1880 que Charles Louis Alphonse Laveran descobriu o agente causador da doença ao identificar, no sangue fresco de um soldado doente, a presença de grânulos pigmentados e formas que se movimentavam freneticamente, batizando-os de Oscillaria malariae. Cinco anos depois, em 1885, dois patologistas italianos, Marchiafava e Celli, identificaram uma forma amebóide em anel nas hemácias de pacientes com a doença, conferindo-lhe o nome de Plasmodium (DAWES, 1988).

Em 1897, na India, Ronald Ross descobriu o vetor da malária aviária. Um ano após, um grupo de pesquisadores italianos liderado por Batista Grassi descobriu que o vetor da malária era um mosquito anofelino. Somente cerca de 50 anos depois, em 1948, é que Garnham, estudando macacos foi capaz de descrever o estágio hepático do Plasmodium cynomolgi. Neste trabalho, os autores observaram que havia uma fase negativa no sangue, ou seja, ausência de formas sanguíneas, que durava de 1 hora a 6 dias após a inoculação de esporozoítos. Dois anos após, foram descritos os estágios hepáticos do $P$. vivax e do $P$. falciparum (DAWES, 1988).

Durante a primeira e segunda guerras mundiais, milhares de soldados foram dizimados pela malária. A partir deste momento, a incidência da doença caiu progressivamente, principalmente em países como Estados Unidos, Itália, Grécia e Espanha. Esta queda se atribuiu principalmente ao desenvolvimento socioeconômico e intervenções antimaláricas como: melhorias na habitação, drenagem de pântanos, com a consequente eliminação de criadores de mosquitos, 
uso de inseticidas como o DDT (difenildiclorotrietano) e a utilização de drogas como a cloroquina, a primaquina, a amodiaquina, a proguanil e a pirimetamina (SACHS e MALANEY, 2002).

Pesquisas para o desenvolvimento de uma vacina capaz de eliminar a malária começaram a surgir no final da década de 60 . Utilizando esporozoítos de $P$. berghei, Nussenzweig e colaboradores demonstraram que camundongos poderiam ser imunizados por repetidas inoculações por meio de injeção intravenosa de esporozoítos irradiados e que essa imunização seria estágio-específica (NUSSENZWEIG et al., 1967). Em seguida, na década de 70, Clyde obteve resultado semelhante, com $P$. falciparum e $P$. vivax, indicando que a imunidade induzida seria espécie e estágio-específica e não cepa-específica (CLYDE, 1990).

Acredita-se que para o desenvolvimento de vacina para malária, o primeiro passo é a identificação de antígenos adequados e a apresentação destes em um formato ou formulação que induza uma resposta imune eficiente. Em formato, incluise peptídeos sintéticos, lipopeptídeos, proteínas recombinantes nativas, entre outros (REED et al., 2006). Já, para formulação, o uso de adjuvantes apropriados como hidróxido de alumínio (alum). Além deste, já foi demonstrado que vacina para málaria formulada com o adjuvante AS02A, uma emulsão oléo-água que contém derivados de saponina (QS21) e lípidio monofosforilado $A(M P L)$, se mostrou segura e altamente imunogênica (PICHYANGKUL et al., 2004).

Os mecanismos de penetração dos esporozoítos nos hepatócitos têm sido amplamente estudados por se acreditar que uma vacina contra antígenos das formas pré- eritrocíticas seria a melhor estratégia de imunização ativa conferindo imunidade estéril (GRAVES e GELBAND, 2006). Neste contexto, um dos alvos é a proteína TRAP, utilizada para penetração dos esporozoítos nos hepatócitos (SULTAN et al., 1997).

Os antígenos-alvo dos candidatos a vacina para a forma assexual do parasita se resumem basicamente em 3: CSP(Circumsporozoite protein), MSP-1 (Merozoite Surface Protein) e AMA-1 (Apical Membrane Antigen). A frequência de uso dos mesmos antígenos, em diferentes formatos de apresentação, é devida a falta de conhecimento de uma adequada reposta imune protetiva (REED et al., 2006).

Atualmente, mais de 70 formulações de vacinas estão disponíveis, e destas cerca de 20 estão em testes clínicos (HERRERA et al., 2007). 


\subsection{ASPECTOS GERAIS}

A malária, segundo a Organização Mundial de Saúde (OMS), é a doença parasitária mais importante do mundo. Considerada como uma doença infecciosa aguda é causada pelo protozoário do gênero Plasmodium e transmitida naturalmente ao homem pela picada da fêmea do mosquito do gênero Anopheles, durante seu repasto sanguíneo (WORLD HEALTH ORGANIZATION, 2010). Embora, entre os anos de 1945 e 2010, aproximadamente 79 países terem eliminado a doença, atualmente metade da população mundial, cerca de 3,3 bilhões de pessoas em mais de 103 países, encontram-se em áreas de risco de infecção, especialmente populações pobres de regiões tropicais e subtropicais (Fig. 1) (FEACHEM et al., 2010).

Estimam-se cerca de 225 milhões de casos de malária, principalmente na região africana ( $85 \%$ dos casos), causando aproximadamente 800 mil óbitos por ano, sobretudo de crianças menores de cinco anos, mulheres grávidas e adultos não imunes (WHO, 2010). Pesquisas indicam que uma criança morra de malária no mundo a cada 40 segundos, resultando em uma perda de mais de 2.000 vidas diariamente. Assim a malária é considerada com uma das três principais doenças transmissíveis causadoras de morte (SACHS e MALANEY, 2002). 
Figura 1- Áreas de risco de transmissão por malária

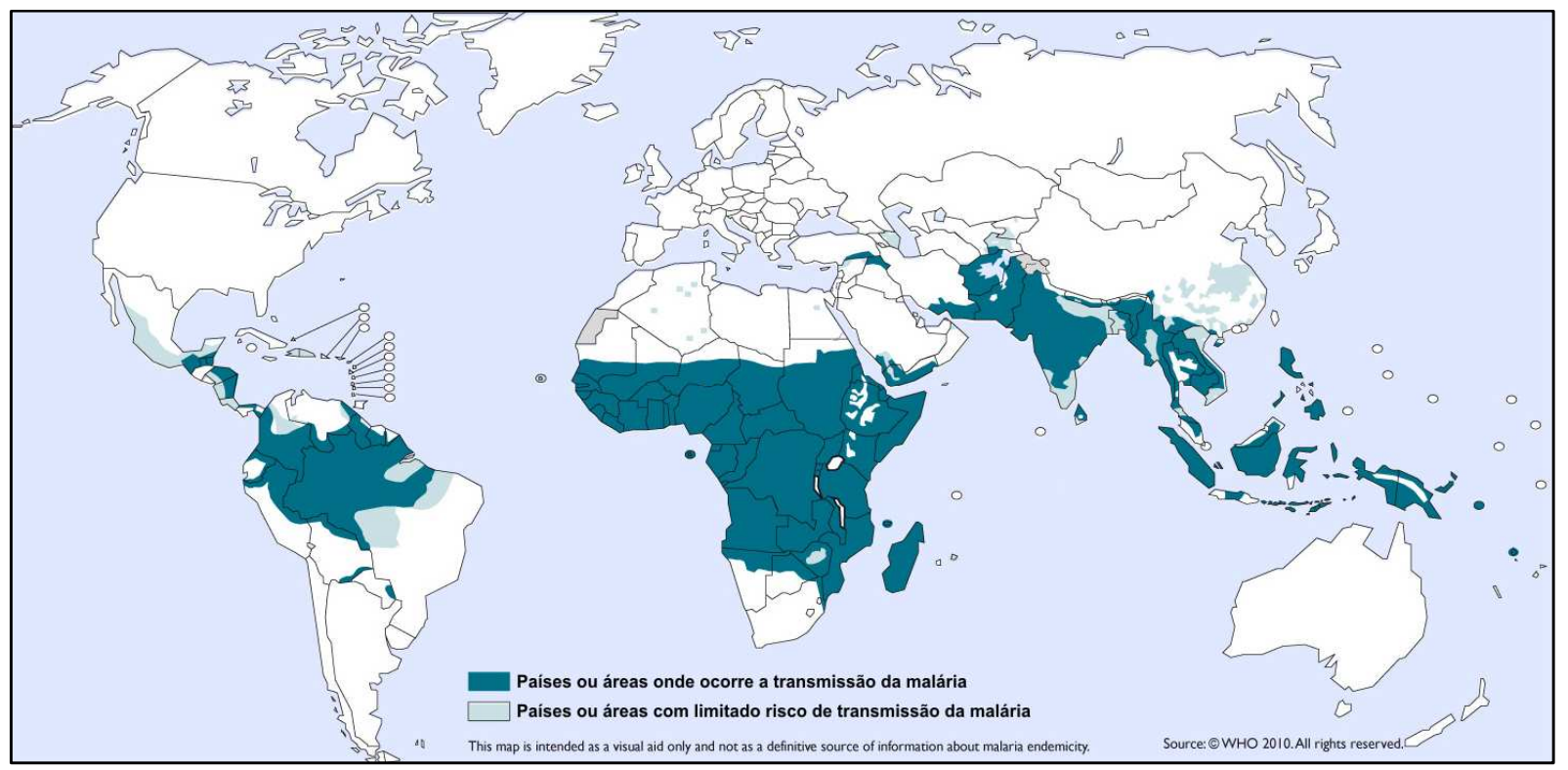

llustração mostrando a distribuição das áreas com risco de transmissão de malária no mundo, evidenciando a ocorrência concentrada principalmente na região tropical. Fonte: modificado de (WHO, 2011)

O Brasil é responsável por um número expressivo dos casos de malária notificados na América Latina, ocorrendo em média 500 mil casos por ano. Só em 2009, foram registrados aproximadamente 306 mil casos da doença, principalmente na região amazônica. Nesta região prevalecem características sócio-econômicas e ambientais favoráveis à permanência dos plasmódios, como a presença de criadouros naturais do vetor e o contato mais aproximado do mesmo com o homem, resultando na forma natural de transmissão da doença (OLIVEIRA-FERREIRA et al., 2010).

Diferentes determinantes epidemiológicos como clima, forma de ocupação do solo, modalidade de exploração dos recursos naturais e da intensa migração de área rural para urbana aumentam a probabilidade de infecção malárica. A precária vigilância epidemiológica e entomológica e áreas que sofreram ações antrópicas, como o desmatamento, contribuem para o agravamento deste quadro (SARAIVA et al., 2009).

O risco de contrair a doença não é uniforme, sendo medido por índice parasitário anual (IPA). Este índice classifica as áreas de transmissão em alto risco(IPA maior que 49,9 casos de malária por mil habitantes); médio risco- (IPA entre 10 
e 49,9 casos/1.000 habitantes), baixo risco- (IPA de 0,1 a 9,9 casos/1.000 habitantes), e zero - sem risco (Fig. 2) (SARAIVA et al., 2009).

\section{Figura 2- Áreas de risco de infecção por malária}

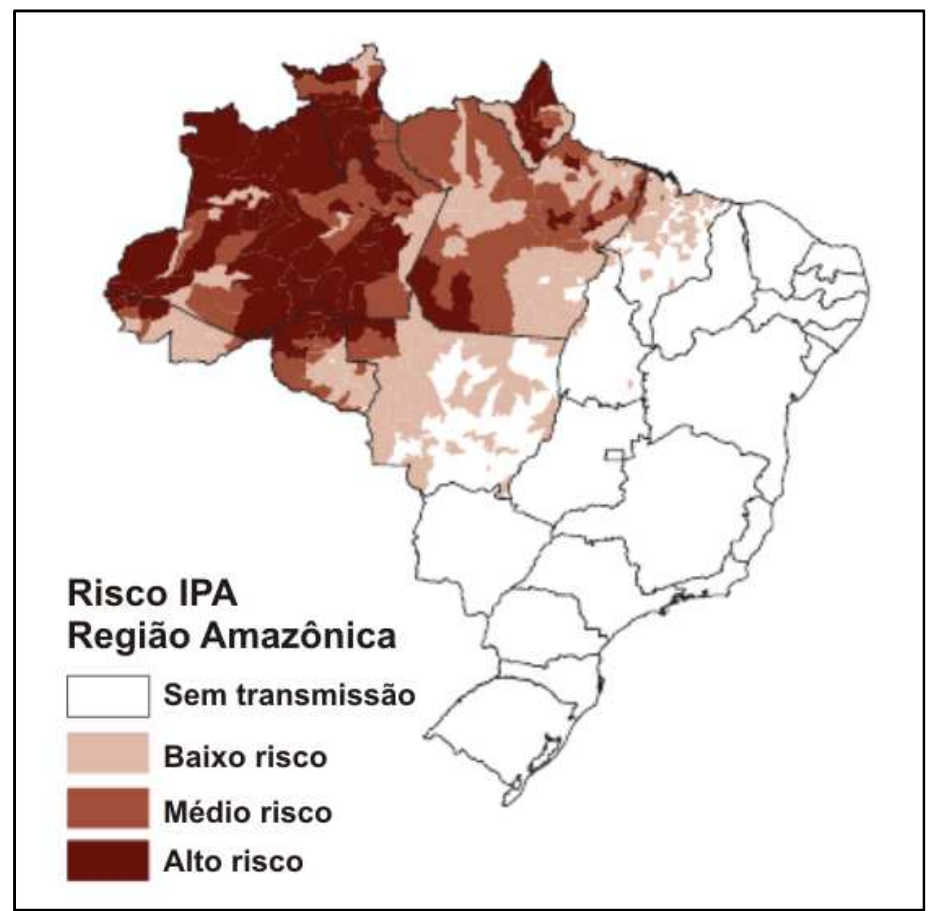

Distribuição das áreas com risco de transmissão de malária no Brasil com base na incidência parasitária anual (IPA). Evidenciando a ocorrência concentrada principalmente na região amazônica. Fonte: modificado de (MINISTÉRIO DA SAÚDE, 2010).

Atualmente estão descritas cinco espécies de Plasmodium que infectam humanos: P. vivax, P. falciparum, P. malariae, $P$. ovale e $P$. knowlesi, sendo que no Brasil, as espécies de maior importância são $P$. falciparum e $P$. vivax.

$P$. falciparum é responsável pela febre terçã maligna caracterizada pelos acessos febris em intervalos de 36 a 48 horas. Esta espécie é a mais virulenta sendo responsável pela maioria das mortes causadas pela doença (GARCIA et al., 2001).

A característica fundamental da patogênese relacionada a esta espécie é a adesão de eritrócitos infectados às células endoteliais da microvasculatura de órgãos como cérebro, e células epiteliais da placenta, devido a presença de receptores específicos encontrados nestes, como CD36 e CSA. Isto resulta em um baixo fluxo sanguíneo, infiltração de células inflamatórias e liberação de mediadores pró-inflamatórios, causando alterações tissulares que caracterizam as formas graves da doença. Além disso, a adesão promove o desaparecimento das formas 
assexuadas do parasita da circulação periférica, evitando assim, que os mesmos sejam destruídos no baço (GREENWOOD et al., 2008).

$P$. vivax é o agente causador da febre terçã benigna, com acessos febris em intervalos de 48 horas. Apesar de ser considerada benigna, Carvalho e colaboradores demonstraram que há aderência dos eritrócitos infectados pelas formas maduras do parasita às células endoteliais pelo receptor ICAM-1, e pelo receptor CSA, na placenta (CARVALHO et al., 2010). Em adição, Alexandre e colaboradores, identificaram complicações como anemia grave em pacientes na região Amazônica, que levaram a morte associadas com infecção por $P$. vivax (ALEXANDRE et al., 2010). Esta espécie, junto com a $P$. ovale, apresenta algumas formas que podem ficar em estado de latência no hepatócito, sendo chamados de hipnozoítos (do grego hipnos, sono). Estas formas levam à recaídas da doença após períodos de incubação que, em geral, é de seis meses (HULDEN, 2011).

A maioria das infecções no Brasil é causada pelo $P$. vivax (Fig. 3), sendo que em 2009 esta espécie foi responsável por 83,7\%. A imediata presença de formas sexuadas do parasita no sangue dos indivíduos infectados, a existência das formas hipnozoíticas, os efeitos colaterais das medicações e evidências de cepas resistentes a cloroquina são muito provavelmente as causas do aumento dos casos de $P$. vivax (OLIVEIRA-FERREIRA et al., 2010). 
Figura 3- Casos no Brasil, divididos por espécies

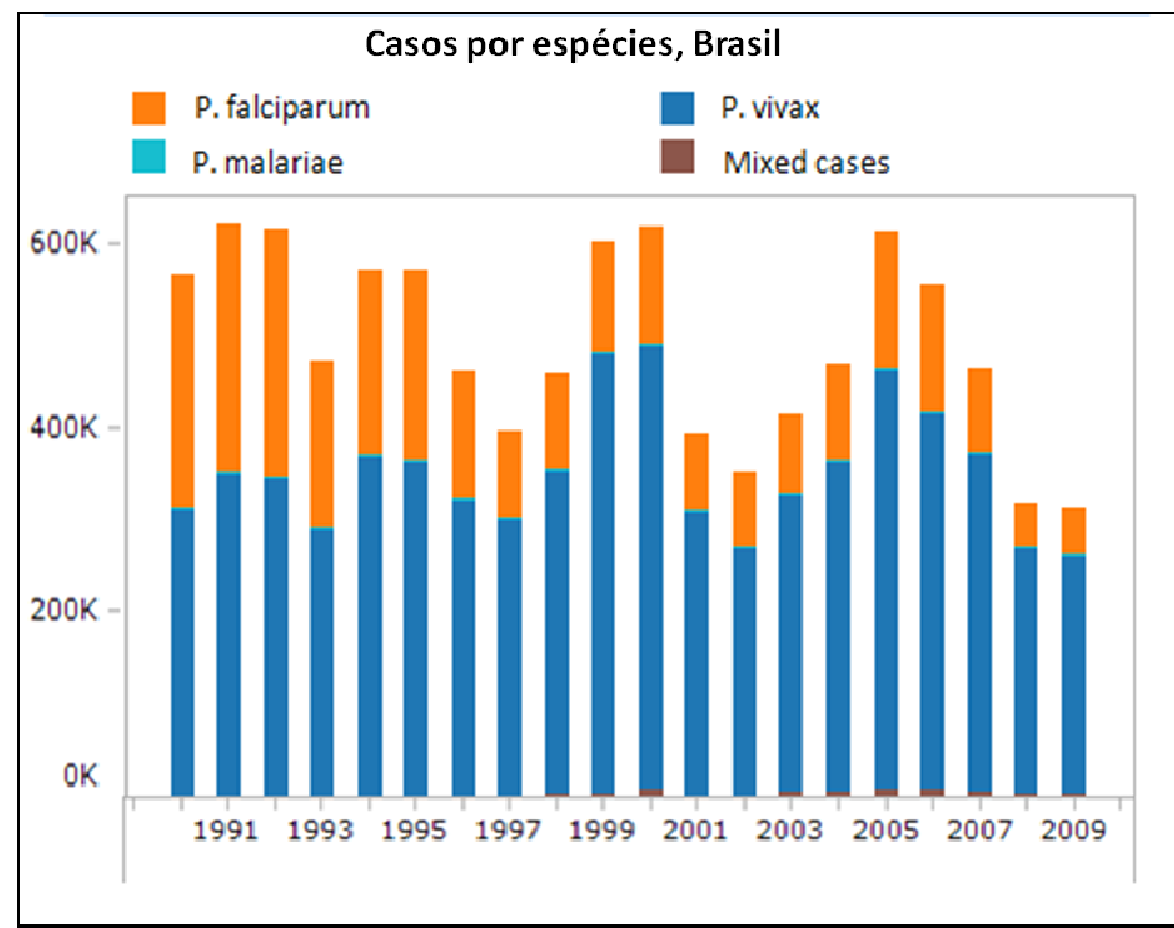

Distribuição dos casos de malária no Brasil, divididos pelas espécies do parasita causadores da doença no homem, ao longo do tempo, com ênfase ao número de casos causados por $P$. vivax. Fonte: modificado de (WHO, 2010).

\subsection{CICLO BIOLÓGICO DO PLASMÓDIO}

Os vetores da malária são mosquitos do gênero Anopheles e suas espécies estão distribuídas pelo mundo, de modo que cada país/região apresenta uma ou mais espécies dominantes na infecção do ser humano. No território brasileiro as principais são: Anopheles darlingi, presente em $80 \%$, A. aquasalis e o A. albitarsis, que compreende um complexo de subespécies. Na África, as predominantes são $A$. gambiae, A. funestus e A. arabienses (PORTES et al., 2010).

O ciclo biológico do plasmódio compreende duas fases: uma fase onde ocorre reprodução sexuada em fêmeas anofelinas (hospedeiro invertebrado-vetor); e outra de reprodução assexuada que se desenvolve no hospedeiro vertebrado. Esta última ocorre em dois ciclos, sendo o primeiro pré-eritrocítico, assintomático, nas células hepáticas e o outro ciclo, eritrocítico, responsável pelos sintomas da doença. As fêmeas anofelinas necessitam se alimentar de sangue para o amadurecimento de seus ovos e assim possibilitar a ovoposição. Assim, após estas ingerirem sangue de um hospedeiro humano contendo as formas sexuadas do parasita (gametócitos femininos e masculinos) inicia-se uma fase sexuada no interior de seu estômago 
com a fecundação e formação de um ovo ou zigoto, chamado de oocineto, que após atravessar a parede intestinal do mosquito, aloja-se na membrana basal onde se desenvolve em oocisto. No interior do oocisto ocorre uma diferenciação que culmina com a produção de esporozoítos (esporogonia). Estes migram para as glândulas salivares do inseto, os quais poderão, no momento da picada, serem inoculados no ser humano (BARILLAS-MURY e KUMAR, 2005).

Ao picar o homem, essas fêmeas injetam uma pequena quantidade de saliva, onde está presente uma enzima com atividade de peroxidase que degrada a serotonina, liberada pelas plaquetas, e assim a vasoconstricção é bloqueada. É nesta saliva que os esporozoítos (formas infectantes do parasita) são encontrados. Após a inoculação destes, passa-se um breve período de cerca de 30 minutos que circulam livres pelo sangue. Em seguida, os esporozoítos invadem as células do fígado (hepatócitos), onde ocorre a primeira divisão assexuada (esquizogonia tecidual), dando origem aos merozoítos, que vão romper os hepatócitos, cair na corrente sanguínea e invadir as hemácias (YAMAUCHI et al., 2007).

Dentro dos eritrócitos, ocorre a esquizogonia eritrocítica, em ciclos variáveis, de acordo com a espécie do parasita (de 24 à 72 h), onde novos merozoítos serão formados. Estes rompem a hemácia e invadem outras, dando início a ciclos repetitivos de multiplicação eritrocitária. Alguns merozoítos diferenciam-se em gametas masculinos (microgametas) e outros em femininos (macrogametas). Numa nova picada, os gametas serão ingeridos pelo mosquito e neste irão fecundar-se dando origem às formas de esporozoítos que irão continuar o ciclo (GARCIA et al., 2001). 
Figura 4- Ciclo biológico do plasmódio

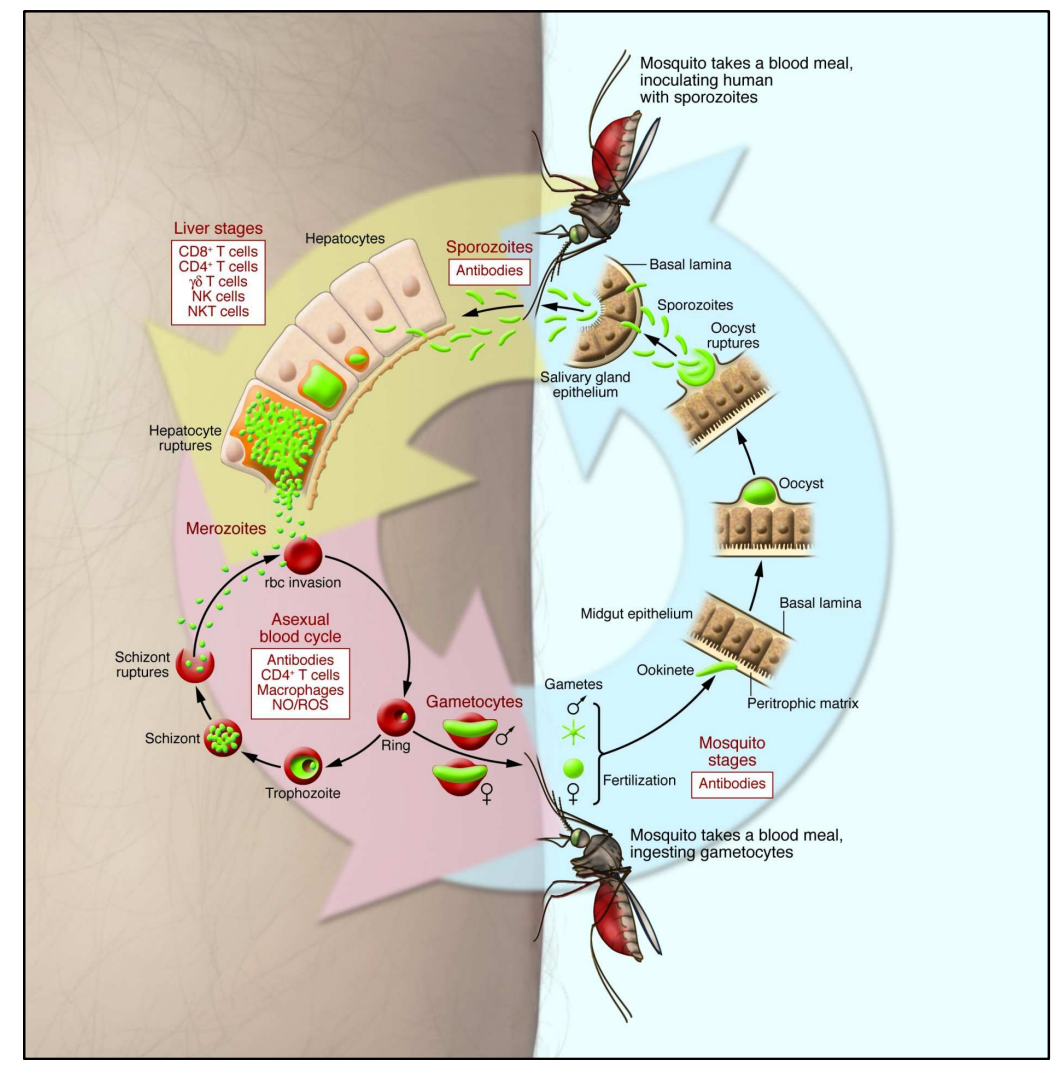

Parasitas na forma de esporozoítos são inoculados na pele do ser humano pela picada do mosquito vetor. Os parasitas seguem para o fígado onde geram a fase hepática da doença de onde saem para dar origem à fase sanguínea onde se observa o quadro sintomatológico. Fonte: (CROMPTON et al., 2010).

Além dos sintomas já citados, que correspondem a um quadro de malária não complicada, pode ocorrer um agravamento do quadro infeccioso, causado em decorrência principalmente de infecções por $P$. falciparum e que é responsável por grande número de mortes em regiões tropicais. Este quadro é considerado como malária grave ou severa, sendo que três fatores são importantes para virulência do plasmódio: capacidade de multiplicação (para cada esporozoíto de $P$. falciparum que penetra no hepatócito, são formados 40 mil merozoítos, quatro vezes mais do que $P$.vivax); preferência por determinado estágio de vida da hemácia ( $P$. falciparum: hemácias de todas as idades, enquanto $P$. vivax invade apenas reticulócitos) e por fim, pela capacidade do parasita ser sequestrado na micro circulação periférica, fenômeno conhecido como citoaderência (MILLER et al., 2002).

Concomitantemente a estes fatores, as inadequadas condições de diagnóstico e tratamento da doença, resultam em maiores parasitemias e maior risco de desenvolvimento de complicações, relacionadas com surgimento de hemorragia, 
convulsão, edema pulmonar, insuficiência renal, entre outras. Os grupos com manifestações mais graves são as gestantes, crianças (com idade de 1 mês a 5 anos) e primoinfectados (TRAMPUZ et al., 2003).

\subsection{MALÁRIA GESTACIONAL}

O termo malária associada à gravidez (PAM, do inglês, Pregnancy Associated Malaria) é usado para se referir a qualquer infecção por plasmódio que ocorre durante a gestação, independentemente da espécie do hospedeiro e da espécie do parasita, sem considerar ainda, o envolvimento placentário. Por exemplo, aumento da incidência de complicações como malária cerebral durante a gestação. Além disso, este termo é usado restritamente para se referir a infecção placentária causada por $P$. falciparum. Já malária placentária (PM, do inglês, Placental Malaria) indica um mecanismo patogênico relacionado especificamente à placenta, excluindo outros fenômenos que possam estar associados à gestação (HVIID et al., 2010).

Entre os adultos expostos à malária, as mulheres grávidas são mais suscetíveis à infecção, constituindo um dos principais grupos de risco. Cerca de 125 milhões de mulheres engravidam, por ano, em zonas endêmicas, aumentando consideravelmente o risco de sofrerem as complicações associadas às infecções pelo Plasmodium falciparum e consequentemente o desenvolvimento de malária placentária (PM) (DELLICOUR et al., 2010). Este quadro é observado principalmente em infecções por $P$. falciparum, porém estudos apontam para a gravidade da doença ocasionada por P. vivax (KALILANI et al., 2010). Nayak e colaboradores mostraram que a anemia materna causada por $P$. vivax é a complicação mais comum durante a gestação, entretanto podem surgir outras consequências como sangramento vaginal, aborto, parto prematuro, hipoglicemia, trombocitopenia e síndrome respiratória aguda (NAYAK et al., 2009). Além disso, malária vivax causa baixo peso ao nascer, que foi associado à ligação do parasita a placenta por meio do receptor CSA (NOSTEN et al., 1999).

Um dos efeitos da malária gestacional sobre o recém-nascido é o baixo peso ao nascer, definido como inferior a $2500 \mathrm{~g}$, principalmente em áreas de transmissão estável. As consequências imediatas são hipotermia neonatal, hipoglicemia e aumento do risco de mortalidade. A longo prazo, as sequelas da infecção incluem 
comprometimento do desenvolvimento neurológico e metabólico, crescimento deficiente e problemas crônicos na idade adulta (ARIBODOR et al., 2009).

A infecção, durante a gestação, é responsável por 10.000 óbitos maternos e aproximadamente 20.000 óbitos de crianças no primeiro ano de vida, resultado do baixo peso ao nascer (CHAGAS et al., 2009).

O motivo pelo qual as mulheres grávidas são particularmente suscetíveis à malária tem sido foco de intenso debate nos últimos anos. Inicialmente foi proposto que a maior suscetibilidade seria devido apenas à imunosupressão materna, que protege o feto contra a ação do sistema imunológico, mas que por outro lado a deixa menos resistente às infecções (MENENDEZ, 1995, NOSTEN et al., 2004). Entretanto, sabe-se que a placenta oferece um ambiente único para o desenvolvimento de sub-populações do parasita que se ligam a receptores como a Condroitina Sulfato $A$ (CSA) presentes em grande quantidade neste órgão (FRIED e DUFFY, 1996).

A gravidade da malária placentária está diretamente relacionada com o nível de endemicidade (LUXEMBURGER et al., 1997). Em zonas de baixa transmissão, onde não se observa altos níveis de imunidade contra a malária, devido à baixa taxa de exposição ao parasita, normalmente a doença é mais expressiva e sintomática, com maior risco de desenvolver doença grave. A mortalidade materna nestas zonas pode resultar diretamente do desenvolvimento de malária grave ou indiretamente pela anemia em consequência da doença (WHO, 2004).

Por outro lado, em zonas de transmissão moderada e alta, consideradas estáveis, devido à constante exposição ao parasita, o desenvolvimento da imunidade é assegurado e poucos sintomas da doença são observados. Nestas áreas, crianças até os cinco anos de idade desenvolvem mais facilmente a doença aguda, sendo menos comum nos adultos. Já, nas grávidas, o impacto da infecção está associado à anemia e a presença de parasitas na placenta, que juntos vão contribuir para um deficiente aporte nutricional ao feto, determinando baixo peso ao nascer com consequente aumento da mortalidade infantil nessas zonas (NOSTEN et al., 2004).

Outro fator que influencia a susceptibilidade a malária placentária é a frequência de paridade. Mulheres multíparas, que já tiveram mais de um parto, apresentam uma menor prevalência da doença e das alterações histopatológicas na 
placenta, enquanto que os mais graves efeitos são observados nas primeiras gestações, sugerindo a existência de um forte mecanismo de proteção associado à imunidade específica e que poderia ser reforçado pela vacinação (NOSTEN et al., 2004, KALILANI et al., 2010).

Isto está relacionado com a pressão evolutiva sobre o $P$. falciparum, que selecionou parasitas com capacidade de adesão ao endotélio microvascular, evitando sua destruição no baço. Este mecanismo de citoaderência envolve o aparecimento de protusões elétron-densas, chamadas de knobs na superfície dos eritrócitos infectados (MILLER et al., 2002). Estes knobs são formados por proteínas codificadas pelo parasita, que são exportadas para a superfície do eritrócito, tais como PfEMP1(HO e WHITE, 1999). Esta proteína altamente variável é codificada pela família dos genes var, sendo que existem aproximadamente 60 genes var por genoma do parasita que vão codificar cerca de 60 variantes diferentes de PfEMP1. Os principais receptores endoteliais são CD36, molécula de adesão ICAM-1, CSA entre outros (KIRCHGATTER e DEL PORTILLO, 2005, KYES et al., 2007).

$\mathrm{Na}$ malária gestacional, os eritrócitos parasitados expressam na sua membrana uma variante da proteína PfEMP1, codificada pelo alelo var2csa, que tem grande afinidade pelo receptor CSA. Este receptor é um membro da família de glicosaminoglicanos polissacarídeos que contem unidades de repetição constituídas por ácido glucorônico-galactosamina-sulfato. Os resíduos de $\mathrm{N}$-acetilgalactosamina são sulfatados em C-4, entretanto os receptores presentes no espaço interviloso da placenta e no sinciciotrofoblasto possuem pequena sulfatação e com isso os eritrócitos parasitados se ligam com alta afinidade, consequentemente observa-se 0 sequestro destes eritrócitos (GOEL e GOWDA, 2011).

É também durante esse período que o sistema imune pode gerar uma resposta específica contra essa variante. Quando antígenos são apresentados apropriadamente, células do sistema imunológico respondem à infecção; à medida que a gestação progride, a resposta local torna-se mais efetiva, limitando a replicação e possibilitando a destruição parasitária. Esse mecanismo torna-se progressivamente eficiente com gestações sucessivas (MCGREGOR, 1984). Assim, mulheres multíparas, que foram infectadas durante a primeira gravidez, são capazes de gerar uma resposta imune mais efetiva contra o plasmódio. Isso se deve à presença de anticorpos capazes de prevenir o sequestro de eritrócitos parasitados 
por bloquear a ligação destes as moléculas de adesão no endotélio vascular (STAALSOE et al., 2004). A geração de uma resposta imune específica pode atenuar significativamente as sequelas decorrentes da malária placentária. Estas sequelas podem levar ao aborto, restrição do crescimento intra-uterino, anemia e infecção congênita nos fetos. Já para o recém-nascido pode ocasionar prematuridade, baixo peso ao nascer e natimortalidade (ROGERSON et al., 2007).

\section{Figura 5- Sequestro de eritrócitos parasitados na placenta}

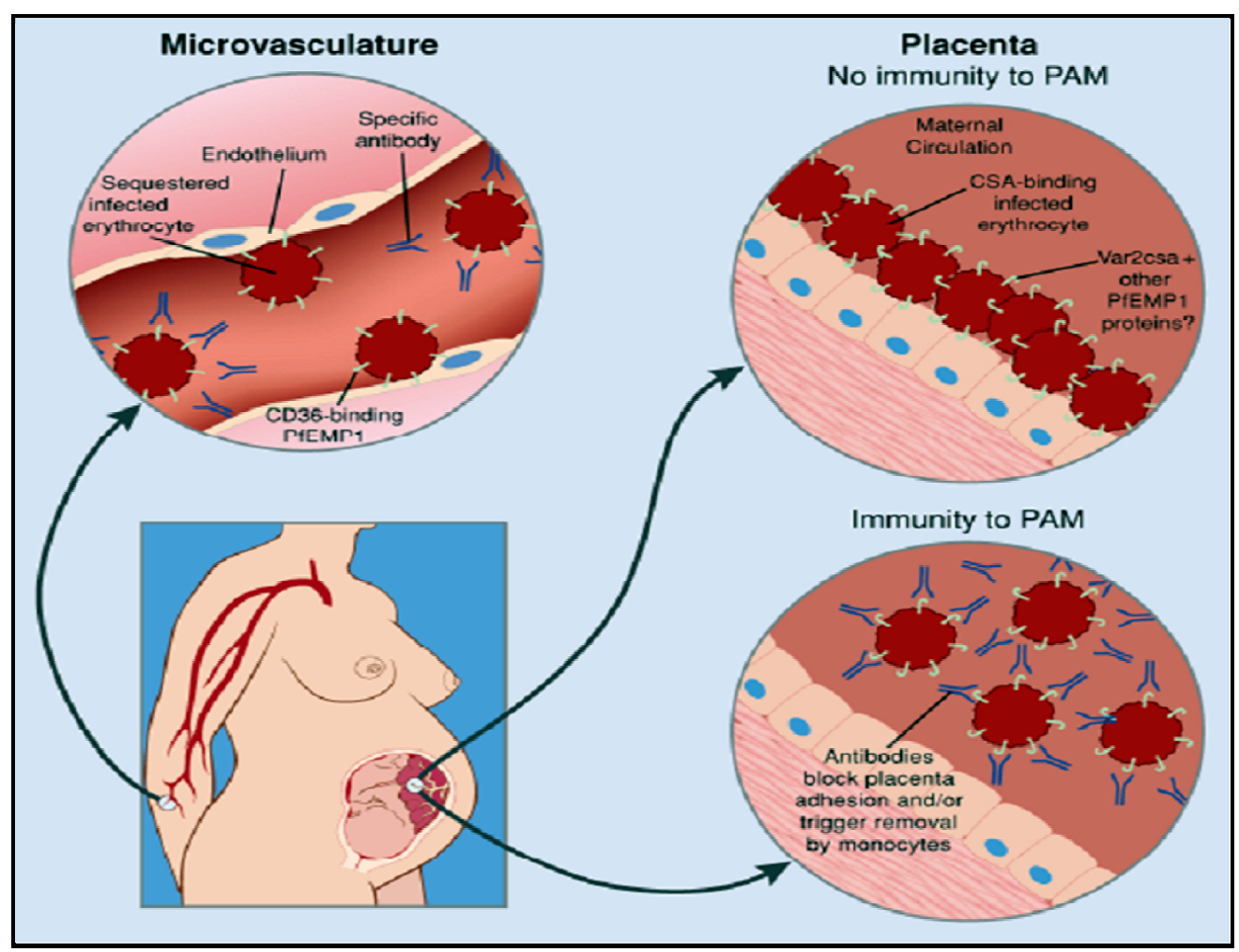

Ligação de eritrócitos infectados na microvasculatura endotelial da placenta. Mulheres grávidas, principalmente as primigrávidas, são mais suscetíveis ao sequestro de eritrócitos infectados na placenta. EP placentários são antigenicamente e funcionalmente distintos dos encontrados sistemicamente e não se ligam ao receptor CD36 e sim ao CSA. Estes EP que se ligam ao CSA são raros em infecções antes da gravidez, e por isso conseguem escapar do sistema imune e provocar infecções mais severas na placenta. Durante a gravidez, as mulheres desenvolvem anticorpos contra essa variante do parasita, os quais podem bloquear ligação de eritrócitos infectados ou opsnonizá-los para a destruição por monócitos, reduzindo assim a gravidade da doença em gestações subsequentes. Fonte: (GAMAIN et al., 2002).

\subsection{RESPOSTA IMUNE NA MALÁRIA}

Como em qualquer infecção, o sistema imune inato é o primeiro a reconhecer o plasmódio, seja ele na forma de esporozoíto ou como merozoíto eritrocítico, através de macrófagos, células dendríticas, células $\mathrm{NK}, \mathrm{TCR} \gamma \delta^{+}$e proteínas do 
complemento. Além disso, há secreção de citocinas, potencializando a fagocitose e contribuindo para a ativação de células T CD4 ${ }^{+}$(LUNDIE, 2011).

O curto período de tempo entre a entrada do esporozoíto no indivíduo e a penetração no fígado determina que a eliminação do parasita pelo sistema imune seja extremamente rápida. Citocinas como IL-12 e IFN- $\gamma$ podem neutralizar as formas esporozoítas, assim que caem na corrente sanguínea, antes de invadirem os hepatócitos. A proteína circunsporozoítica que recobre o esporozoíto é um dos principais alvos de reconhecimento do sistema imune e estímulo para a produção de grandes quantidades de IFN- $\gamma$. Esta citocina é produzida por células NK em resposta a IL-12 produzida por macrófagos ativados (ROETYNCK et al., 2006). Além disso, células de Kupffer, macrófagos residentes no fígado, são ativadas e produzem IL-18 impedindo o crescimento de esporozoítas dentro deste órgão. IL-18 tem potencial de ativar a resposta inflamatória através da indução da produção de IFN- $\gamma$ (TSUTSUI et al., 2003). Em adição, células TCD8 ${ }^{+}$(citotóxicas) ativadas pela presença de IFN- $\gamma$ desempenham papel importante de eliminação parasitária, agindo durante a replicação nas células hepáticas (REID, 1998).

Já a eliminação do parasita no sangue requer a intervenção de células $T$ $\mathrm{CD}^{+}$para o controle da parasitemia e de células $\mathrm{B}$ com a finalidade da síntese de anticorpos, sendo que os principais alvos antigênicos do reconhecimento humoral são as proteínas PfEMP1. Os eritrócitos parasitados induzem a produção de TNF- $\alpha$, IL-12 e IFN- $\gamma$ pelas células mononucleares sanguíneas (HAFALLA et al., 2011). Anticorpos das subclasses IgG1 e lgG3 em humanos têm alta afinidade por receptores Fc presentes na superfície de fagócitos, assim como possuem alta afinidade por proteínas do sistema complemento, ativando a via clássica deste sistema (LAZAROU et al., 2009).

Apesar de a resposta imune ao plasmódio ser eficiente, se for rápida, e contar com componentes pró-inflamatórios, que possam controlar ou eliminar os eritrócitos infectados, esta resposta deve ser suprimida por mediadores anti-inflamatórios, a partir do momento em que a carga parasitária esteja controlada, evitando assim, danos ocasionados pela própria resposta, que é amplificada, podendo levar ao quadro de malária grave (RILEY et al., 2006). Já foi demonstrada uma correlação entre a gravidade da doença e níveis circulantes de citocinas, principalmente TNF- $\alpha$, que está correlacionada com surtos de febre da doença, além de estar 
potencialmente envolvida com interrupção da gravidez (POOVASSERY e MOORE, 2009). Além disso, a produção de óxido nítrico na cascata de sinalização de TNF- $\alpha$ pode gerar sintomas encontrados na malária grave como: hipotensão, acidose láctica, hipoglicemia e coma (MENDIS e CARTER, 1992).

Esses dados apontam para uma imunidade parcial que pode ser adquirida progressivamente para as formas graves da doença, após poucas infecções. Entretanto esta imunidade não é esterilizante, mesmo com um extenso período de exposição, sendo, portanto, necessária persistência da carga parasitária para a manutenção da população de células de memória (STEVENSON e RILEY, 2004).

Devido a diversidade antigênica promovida pela presença dos genes var em P. falciparum, que induzem uma modificação na expressão da proteína PfEMP1, dificultando a completa eliminação do parasita, a imunidade contra os estágios sanguíneos é adquirida de forma insuficiente. Além disso, a imunidade contra as formas hepáticas vem a ser falha, possivelmente relacionada à supressão da resposta imunológica ou ainda devido a uma insuficiente imunoestimulação (BORRMANN e MATUSCHEWSKI, 2011).

\subsection{RESPOSTA IMUNE NA MALÁRIA PLACENTÁRIA}

A placenta é um órgão que surge com o crescimento do feto e das suas necessidades nutricionais, tem como função a troca de produtos metabólicos como nutrientes e eletrólitos, gases e transmissão de anticorpos da mãe para o feto. Sendo assim, a primeira linha de defesa contra a infecção malárica ocorre neste órgão (REZENDE FILHO e MONTENEGRO, 2011).

A cada gestação a placenta e a circulação útero-placentária, são formadas sem desafio prévio à infecção malárica, portanto sem imunidade específica local. Quando antígenos são apresentados apropriadamente, células imunes maternas respondem à infecção; à medida que a gestação progride a resposta local torna-se mais efetiva, limitando a replicação e possibilitando a destruição parasitária (MCGREGOR, 1984).

A resposta imune durante a gravidez varia entre a resposta Th1, importante para implantação do feto e durante o momento do parto, e uma resposta Th2, propícia para manutenção da gestação. No entanto, em casos de malária, há alteração no perfil imune para Th1 (FRIED et al., 1998). Esta resposta Th1 durante a 
gestação está associada com anemia materna, aborto espontâneo e parto prematuro (ROGERSON et al., 2007).

O espaço interviloso placentário abriga linfócitos que são determinantes na evolução da infecção. Na presença do parasita ou produtos derivados dele, por exemplo, hemozoína, as células mononucleares maternas e do sinciciotrofoblasto liberam quimiocinas, como MIP-1a (do inglês, Macrophage-Inflammatory Protein 1), MCP-1 (do inglês, Monocyte Chemoattractant Protein 1) e IL-8, que favorecem o recrutamento de monócitos (ROGERSON e BOEUF, 2007, LUCCHI et al., 2008). Um intenso infiltrado inflamatório constituído predominantemente por macrófagos/monócitos desenvolve-se nesse espaço, com consequente produção de citocinas pró-inflamatórias, tais como TNF- $\alpha, \mathrm{IFN}-\gamma$, IL-1 $1 \beta$, óxido nítrico e espécies intermediárias de oxigênio, que auxiliam na eliminação do parasita por aumentar a atividade fagocítica de macrófagos e estimular a proliferação de células $T$. Por outro lado, levam a deterioração da função placentária (MENENDEZ, 1995).

Os efeitos mais severos da malária são observados em áreas de baixa endemicidade em consequência da gravidez associada com a resposta de células mediadoras da reposta imune, como as células $\mathrm{T}$, ou a ausência de níveis adequados de anticorpos específicos (SMITH, 1996). Além disso, as mulheres multíparas são menos susceptíveis a infecção do que primíparas, devido a aquisição da resposta humoral para malária, durante o curso da primeira gravidez, reduzindo 0 risco da infecção em gravidez subsequente (DESAl et al., 2007).

Através da presença da hemozoína (pigmento malárico), do parasita e da inflamação, pode-se classificar histologicamente a malária placentária em: ativa, onde os parasitas são encontrados nos espaços intervilosos e ausência ou mínima presença do pigmento malárico; crônica, presença do parasita e do pigmento malárico também nos monócitos/macrófagos intervilosos; passada, quando não se identifica o parasita, mas o pigmento é encontrado em locais como depósitos fibrinóides no espaço interviloso, dentro de macrófagos e na decídua basal. $\mathrm{Na}$ malária placentária, estes depósitos de hemozoína estão relacionados com o baixo peso ao nascer (MUEHLENBACHS et al., 2010). 


\subsection{RECRUDESCÊNCIA DA MALÁRIA}

A recrudescência é definida como uma recaída precoce, onde o paciente apresenta "cura clínica", porém, após um ou dois meses ele volta a apresentar os sintomas maláricos. Este fenômeno está relacionado especificamente com infecções por $P$. falciparum durante a gestação e tem uma alta frequência em primigrávidas (VAN ZON et al., 1985). Em contraste, nas infecções por P. vivax, podem ocorrer recaídas de 8 a 10 meses depois dos primeiros ataques de malária. Estas recaídas correspondem a ciclos pré-eritrocíticos e eritrocíticos tardios, devido à esporozoítas que permaneceram quiescentes no fígado durante todo esse tempo, que são chamados de hipnozoítos (HULDEN, 2011).

Mulheres que vivem em áreas de alta transmissão e que, por isso, são constantemente expostas a malária, podem ser mais susceptíveis à infecção durante a gestação. Além disso, a malária pode ser assintomática durante a gravidez e mesmo assim, trazer consequências graves para o feto em desenvolvimento, sugerindo um complexo mecanismo de patogênese ligado a recrudescência, patologia placentária e desenvolvimento intra-uterino (MARINHO et al., 2009).

Entender quais os mecanismos envolvidos neste processo é de difícil observação em humanos, pois a recrudescência é facilmente confundida com uma re-infecção, devido a constante transmissão nessas áreas. No entanto, existem estudos feitos com pacientes africanos, indicando recrudescência, através da genotipagem do parasita. Sutherland e colaboradores analisaram amostras de pacientes com málaria causada por $P$. falciparum através de amplificação de DNA por PCR e observaram a correlação entre amostra coletada durante a recrudescência e amostra de 26 dias antes, comprovando ser o mesmo parasita (SUTHERLAND et al., 2008). Além disso, Mayor e colaboradores, usando um método de genotipagem, mostraram infecções recrudescentes em $21 \%$ das mulheres que tiveram os parasitas isolados, sem evidências de novas infecções e com um intervalo de tempo médio de 58 dias (MAYOR et al., 2009).

Em camundongos, foi demonstrada pela primeira vez, na década de oitenta, por van Zon e Eling, onde foi observada maior vulnerabilidade em fêmeas grávidas, reforçando a hipótese que o recrudescimento da infecção malárica está associado com a gestação (VAN ZON e ELING, 1980). Duas décadas depois, foi demonstrado 
que fêmeas grávidas acumulavam anticorpos específicos contra o parasita recrudescente (MEGNEKOU et al., 2009).

Recentemente, nosso grupo desenvolveu um modelo experimental, onde se observou que $60 \%$ das fêmeas primíparas, que haviam sido expostas ao parasita anteriormente, apresentaram recrudescência quando grávidas e que o parasita utilizado $P$. berghei fazia adesão placentária (MARINHO et al., 2009). Além disso, as fêmeas recrudescentes com alta parasitemia apresentaram uma redução do espaço vascular, indicando que esta redução é altamente dependente da carga parasitária, sendo assim, o parasita desempenha um importante papel na patologia placentária. Como Van Zon, 1985, também foi visto uma maior incidência de recrudescência em primigrávidas, sugerindo que existe um mecanismo de proteção induzido em multigrávidas, relacionado com a presença de anticorpos capazes de bloquear a adesão placentária (VAN ZON et al., 1985).

Nos últimos anos, muitos estudos têm definido as manifestações clínicas da malária associada à gravidez, no entanto, os mecanismos celulares que conduzem à patologia ainda permanecem obscuros. Uma possível explicação para isto é que estudos em humanos, embora sejam muito importantes, não são suficientes, devido às limitações óbvias intrínsecas aos sistemas experimentais humanos e à acessibilidade ao material biológico nos diferentes estágios da gestação. Assim, os modelos murinos oferecem a possibilidade de estudo dos tipos celulares potencialmente envolvidos na recrudescência da malária experimental durante a gravidez, em condições experimentais, definidas e controladas.

Modelos experimentais murinos de infecção por plasmódio, vem sendo utilizados pelo nosso grupo de pesquisa no estudo das populações e mediadores imunológicos que participam no controle do parasita, bem como na análise dos fatores que propiciam o estabelecimento de lesões nos diferentes tecidos (NERES et al., 2008).

Estes modelos nos permitem conhecer os elementos envolvidos na recrudescência associada à malária gestacional em um sistema experimental que represente um bom modelo animal da enfermidade humana. Estes estudos poderão fornecer conhecimentos relevantes para a compreensão da malária gestacional, particularmente no entendimento dos mecanismos imunológicos envolvidos na recrudescência da infecção durante a gravidez, na aquisição e na transferência de 
imunidade específica, nos estudos de suscetibilidade genética, além de ser uma importante ferramenta para o teste de novas drogas e vacinas.

Assim, face ao quase completo desconhecimento dos elementos determinantes da recrudescência da malária durante a gravidez, o presente projeto tem como objetivo final a identificação e a compreensão dos elementos envolvidos nessa doença, além de possibilitar a possível compreensão da localização do parasita antes do processo de recrudescimento. 
O presente trabalho teve como objetivo central a identificação e a compreensão dos elementos envolvidos na recrudescência da malária durante a gravidez. Neste sentido pretendeu-se:

(i) avaliar os mecanismos da imunidade celular e humoral envolvidos na resistência e suscetibilidade à infecção;

(ii) avaliar a presença de alterações histopatológicas nas placentas de fêmeas primigrávidas com ou sem recrudescência;

(iii) identificar possível reservatório do parasita durante a fase crônica da doença. 


\subsection{ANIMAIS}

Foram utilizados camundongos BALB/c fêmeas e machos com 5-8 semanas de idade fornecidos pelo Biotério do Departamento de Parasitologia do Instituto de Ciências Biomédicas da Universidade de São Paulo. Os animais utilizados na realização dos experimentos foram mantidos em estantes ventiladas sob condições controladas de temperatura, umidade e iluminação. Todos os procedimentos que envolvem animais estão de acordo às diretrizes aprovadas pela Comissão Brasileira de Experimentação Animal (COBEA) e pelas Comissões de Ética do Instituto de Ciências Biomédicas da Universidade de São Paulo.

\subsection{MODELO EXPERIMENTAL}

Camundongos BALB/c fêmeas com cinco semanas, foram infectados via intraperitoneal (i.p) com $10^{4}$ eritrócitos parasitados (E.P.) com Plasmodium berghei ANKA expressando constitutivamente proteína fluorescente verde (GFP) (Fig. 6A). A parasitemia foi avaliada a partir do quarto dia de infecção por citometria de fluxo (FACs- Calibur) da seguinte forma: foram coletados $2 \mu l$ de sangue da cauda do animal e colocados em um tubo contendo 400 $\mu$ de Staining Buffer (PBS 1x, Soro Fetal Bovino 1\%, Azida 0,1 g/ml10\%); os tubos foram levemente agitados, mantidos a $4^{\circ} \mathrm{C}$ e longe da luz e posteriormente as amostras foram avaliadas no citômetro de fluxo. A cada análise foi colhida uma amostra de um animal controle infectado, para a calibração do aparelho. Foram adquiridos 100.000 eventos onde se consideraram infectados os eritrócitos além da linha delimitada pelo controle (Fig. 6B). Os animais foram tratados com cloroquina (0,7mg/animal/dia) por 3 dias consecutivos a partir do sétimo dia para que a parasitemia chegasse a valores indetectáveis. Após duas semanas, foi feito um novo acompanhamento para se detectar o segundo pico de parasitemia (Fig. 6C).

Para reproduzir um quadro de malária similar aquele frequentemente observado em regiões de alta transmissão, utilizamos o mesmo protocolo experimental descrito anteriormente. Além disso, após duas semanas do segundo pico de infecção, coletamos o soro e o denominamos como soro imune. Em seguida, fizemos o primeiro desafio, utilizando a mesma carga parasitária da primeira 
infecção ( $10^{4}$ EP de P. berghei ANKA $\left.{ }^{\text {GFP }}\right)$. Duas semanas após o primeiro desafio, nova amostra de soro foi coletada e foi feito novo desafio nas mesmas condições que o primeiro.

Figura 6- Protocolo experimental com uso de parasitas GFP

A

Infecção com $10^{4}$ EP com P. berghei ANKAGFP

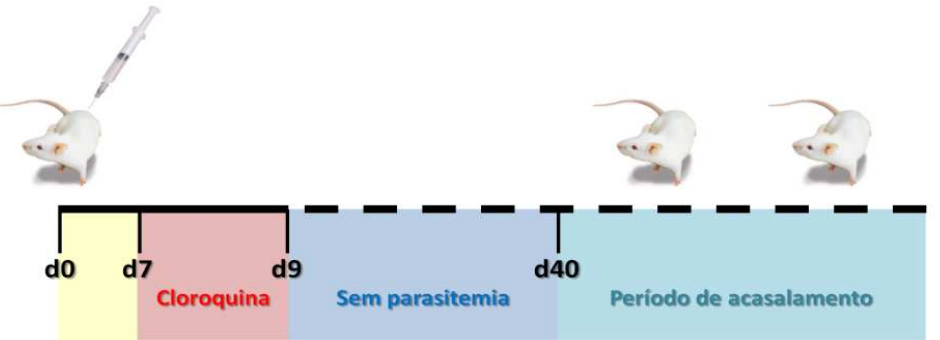

B

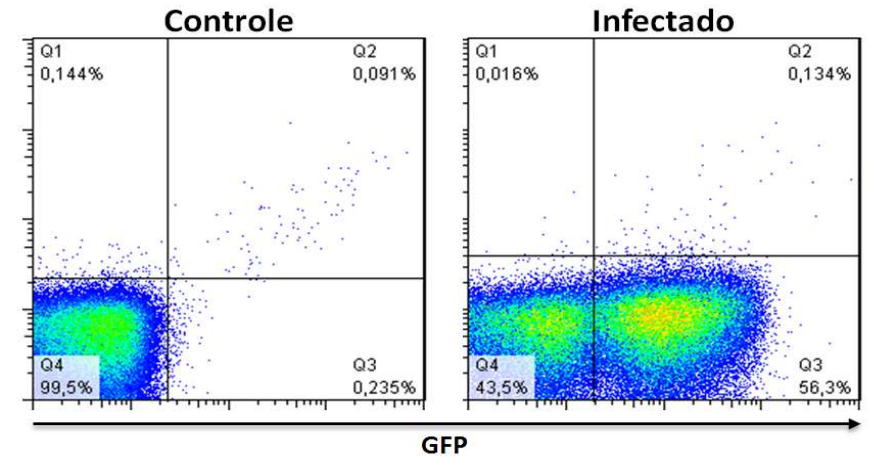

C

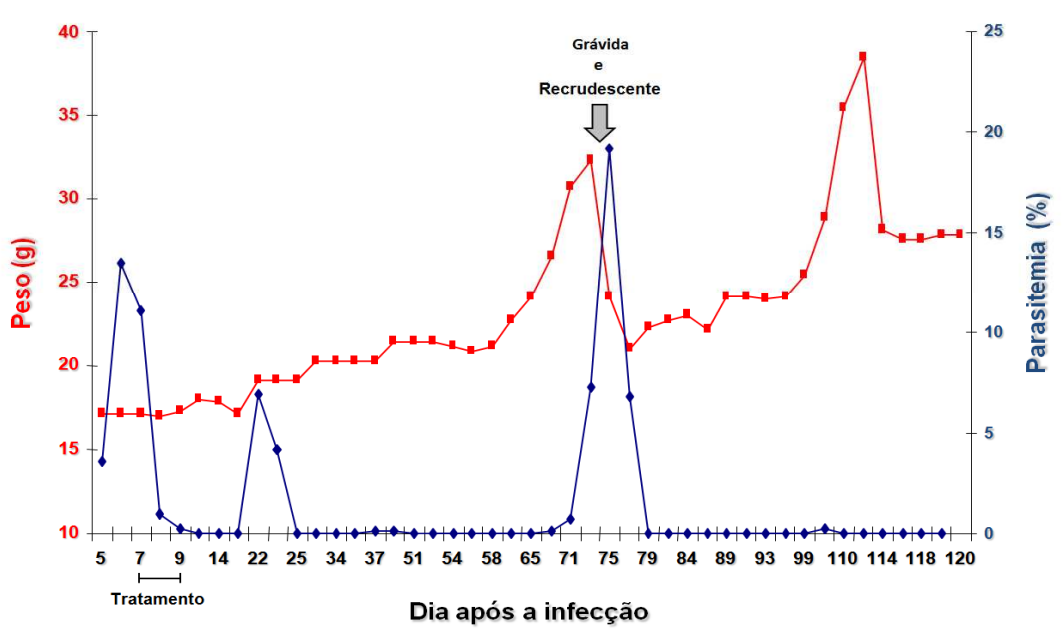

A) Animais BALB/c foram infectados i.p. com $10^{4}$ E.P. de $P$. berghei ${ }^{\text {GFP }}$, sendo o dia de infecção considerado D0. O tratamento com cloroquina $(0,7 \mathrm{mg} / \mathrm{dia} / \mathrm{animal})$ foi feito durante 3 dias a partir do D7. O acasalamento ocorreu cerca de 40 dias após a infecção. (B) Quantificação da porcentagem de eritrócitos infectados positivos para GFP realizada por citometria de fluxo. (C) Representação indicando gravidez pelo peso $(\mathrm{g})$ e recrudescência. 


\subsection{MONITORAMENTO DA GRAVIDEZ}

Quarenta dias após a infecção, fêmeas infectadas ou não foram colocadas para acasalar. Para análise do tempo de gestação verificamos conjuntamente a formação do tampão vaginal e acompanhamos o aumento do peso corporal. $O$ primeiro dia da detecção de tampão vaginal foi considerado dia gestacional 1 (G1). A gravidez foi confirmada entre $\mathrm{G} 10$ e $\mathrm{G} 13$, quando os animais tiveram um aumento médio de 3-4 g no peso corporal. O ganho de peso foi considerado como sinal de gravidez e a súbita perda de peso como um indicador de interrupção da gravidez. A figura 6C mostra o ganho de peso associado com a parasitemia em fêmeas recrudescentes e apenas o ganho de peso em não recrudescentes.

\subsection{ANÁLISE MORFOMÉTRICA}

As análises histológicas e morfométricas das placentas foram realizadas como descrito previamente por Neres e colaboradores (NERES et al., 2008). Em resumo, realizamos a quantificação do espaço vascular de secções de placentas coradas com H\&E. Em cada secção, três regiões dos espaços intervilares foram selecionadas randomicamente e imagens (aumento de 20x) foram adquiridas, utilizando-se uma câmera colorida Zeiss (Axio Cam HRc) conectada a um microscópio de luz Zeiss (Axio imager. M2). Para a análise morfométrica foi utilizado o programa Image J (http://rsbweb.nih.gov/ij/). Resumidamente, depois da aquisição das imagens, foi estipulado um limite de cores às imagens de modo a cobrir as áreas correspondentes ao espaço vascular. A porcentagem das áreas cobertas foi calculada pela razão entre, o número de pixels cobertos na área definida pelo limite e o total de número de pixels da imagem. A área vascular de cada placenta foi estimada pela análise de três cortes não consecutivos. Os resultados apresentados correspondem a fêmeas grávidas individuais e representam um resultado médio entre 3 e 9 placentas por fêmea. 


\subsection{OBTENÇÃO DE CÉLULAS ESPLÊNICAS}

Para obtenção das células esplênicas, baços de fêmeas infectadas e controle foram retirados no $\mathrm{G} 19$, pesados e submetidos à maceração. O macerado foi, então, colocado em $5 \mathrm{ml}$ de meio de cultura RPMI 1640 (Gibco) suplementado com 3\% de Soro Fetal Bovino. O homogenato ficou em repouso no gelo por 5 minutos, após retirou-se $3 \mathrm{ml}$ do sobrenadante. O sobrenadante foi centrifugado a $270 \mathrm{xg}$ por 5 minutos a $4{ }^{\circ} \mathrm{C}$. Para lise das hemácias, a amostra foi incubada com $1 \mathrm{ml}$ de tampão $\mathrm{NH}_{4} \mathrm{Cl}$ Tris-Base ( $\mathrm{pH}$ 7.4) por 3 minutos. Em seguida, as células foram lavadas e ressuspendidas em meio de cultura RPMI $3 \%$ SFB.

\subsection{OBTENÇÃO DE LEUCÓCITOS INTRA-PLACENTÁRIOS}

Para a obtenção de leucócitos intra-placentários, placentas de fêmeas controle e infectadas foram lavadas em solução de PBS. Em seguida, as placentas foram colocadas em meio RPMI (Gibco). Com o auxílio de pinças curvas, estes órgãos foram macerados e mantidos no gelo. Logo após, o macerado foi colocado em $6 \mathrm{ml}$ de solução de digestão composta por $0,2 \mathrm{mg} / \mathrm{ml}$ de Colagenase $2,1 \mu \mathrm{l}$ de DNAse de pâncreas bovino (Sigma) e incubados a $37 \stackrel{\circ}{\circ} \mathrm{C}$ e $5 \% \mathrm{CO}_{2}$, por 40 minutos sob agitação. Os órgãos imersos na solução de digestão foram macerados com auxílio de um êmbolo em cell strainer. O homogenato, agora sem a matriz tecidual, foi centrifugado a $270 \mathrm{xg}$ por $5 \mathrm{~min}$ a $4{ }^{\circ} \mathrm{C}$. O sobrenadante foi descartado e o pellet ressuspendido em $1 \mathrm{ml}$ de tampão de lise por $4 \mathrm{~min}$. As células foram, então, lavadas com $10 \mathrm{ml}$ de PBS $10 \%$ SFB e centrifugado a $80 x g$ por $5 \mathrm{~min}$, à $4{ }^{\circ} \mathrm{C}$. O sobrenadante foi desprezado e as células ressuspendidas em meio RPMI.

\subsection{OBTENÇÃO DE LEUCÓCITOS PULMONARES}

Para a obtenção de leucócitos pulmonares, pulmões de fêmeas em estágio crônico da infecção foram colocados em solução de PBS para lavagem. Em seguida, os pulmões foram colocados em meio RPMI (Gibco). Com o auxílio de pinças curvas, estes órgãos foram macerados e mantidos no gelo. Logo após, o macerado foi colocado em $6 \mathrm{ml}$ de solução de digestão composta por $2 \mathrm{mg} / \mathrm{ml}$ de Colagenase 2, 
$1 \mu \mathrm{l}$ de DNAse de pâncreas bovino (Sigma) e incubados a $37{ }^{\circ} \mathrm{C}$ e $5 \% \mathrm{CO}_{2}$, por 40 minutos sob agitação. Os órgãos imersos na solução de digestão foram macerados com auxílio de um êmbolo em cell strainer. O homogenato, agora sem a matriz tecidual, foi centrifugado a $270 \mathrm{xg}$ por $5 \mathrm{~min}$ a $4{ }^{\circ} \mathrm{C}$. O sobrenadante foi descartado e o pellet ressuspendido em $1 \mathrm{ml}$ de tampão de lise por $4 \mathrm{~min}$. As células foram, então, lavadas com $10 \mathrm{ml}$ de PBS $10 \%$ SFB e centrifugado a $80 \times$ g por $5 \mathrm{~min}$, à $4{ }^{\circ} \mathrm{C}$. $\mathrm{O}$ sobrenadante foi desprezado e as células ressuspendidas em meio RPMI.

\subsection{ANÁLISE POR CITOMETRIA DE FLUXO}

Para avaliar as diferentes populações de células, $10^{6}$ células do baço e da placenta, de fêmeas infectadas e controle não infectado, foram plaqueadas e submetidas à centrifugação a $270 x g$ por 5 minutos a $4{ }^{\circ} \mathrm{C}$ com tampão de marcação. Em seguida, anticorpos monoclonais (BD PharMingen) conjugados com fluorocromos específicos para moléculas de superfície foram adicionados, na proporção 1:100, de acordo com a tabela 1.

Tabela 1. Anticorpos fluorescentes utilizados na análise por citometria de fluxo

\begin{tabular}{cc}
\hline Anticorpo & Fluorocromo \\
\hline anti-mouse TCRy & FITC \\
anti-mouse NK1.1 & FITC \\
anti-mouse F4/80 & PE/PE-Cy5 \\
anti-mouse CD86 & FITC \\
anti-mouse CD19 & PE/ APC-Cy7 \\
anti-mouse CD40 & FITC \\
anti-mouse GR1 & PE/PE-Cy7 \\
anti-mouse CD4 & PE-Cy7/APC-Cy7 \\
anti-mouse CD8 & PE-Cy7/APC-Cy7 \\
anti-mouse CD69 & PERCP \\
anti-mouse CD62L & FITC \\
anti-mouse CD11C & PE-Cy7/APC \\
anti-mouse IA & PE/APC \\
\hline
\end{tabular}




\subsection{QUANTIFICAÇÃO DE CITOCINAS NO SORO}

A quantificação das citocinas IL-10, IL-17A, TNF- $\alpha$, IFN- $\gamma$, IL-6, IL-4 e IL-2 presentes no soro foi realizada pelo método de CBA $^{\mathrm{TM}}$ (Cytometric Bead Array, BD Biosciences, USA). O ensaio foi realizado de acordo com o protocolo sugerido pelo fabricante. Resumidamente, os anticorpos de captura específicos para as citocinas citadas ('beads') foram incubados com amostra ou com os padrões (valores da curva padrão: 5120 pg/ml a 20 pg/ml) juntamente com o reagente de detecção conjugado com PE. As amostras e os padrões foram, então, levados a incubação por duas horas à temperatura ambiente protegidos da luz. Em seguida, as amostras foram lavadas por centrifugação à $200 \times \mathrm{xg}$ durante 3 minutos. O sobrenadante foi descartado e o precipitado contendo as beads foi ressuspendido em tampão de lavagem. A análise da fluorescência produzida pelas beads foi quantificada por citometria de fluxo (FACS Canto) e analisada com o software FCAP Array (BD Biosciences, USA).

\subsection{PREPARO DE ANTÍGENO DE P. berghei}

As formas maduras de $P$. berghei, provenientes de um animal infectado, foram colocadas em solução PBS. Em seguida, foi adicionado percoll $74 \%$ e centrifugado a $810 x g$ por 30 minutos a $15^{\circ} \mathrm{C}$, com aceleração 5 e desaceleração 0 . Formado o gradiente, retirou-se a fase intermediária, que é a que contém os eritrócitos com as formas maduras de Plasmodium. Os parasitas provenientes foram lavados 3 vezes em PBS $\left(450 \mathrm{xg}, 10 \mathrm{~min}, 4{ }^{\circ} \mathrm{C}\right.$ ) e ressuspendidos em $1 \mathrm{ml}$ de PBS. Então, foi adicionado $15 \mu \mathrm{l}$ de saponina (10\%) e novamente centrifugado (3000xg, $5 \mathrm{~min}, 4{ }^{\circ} \mathrm{C}$ ). Após a centrifugação formou-se um pellet escuro (parasitas) e uma camada fina branca (membrana do eritrócito). Foram feitas 4 lavagens com PBS até que todas as membranas foram retiradas. As amostras foram armazenadas a $-80{ }^{\circ} \mathrm{C}$ e a concentração proteica foi da ordem de $300 \mu \mathrm{g} / \mathrm{ml}$. 


\subsection{DETERMINAÇÃO DE ANTICORPOS ESPECÍFICOS PARA P. berghei}

Para dosagem dos anticorpos específicos anti- $P$. berghei no soro de camundongos cronicamente infectados utilizamos o ensaio de ELISA descrito por (AVRAMEAS et al., 1979) com algumas modificações. Para a sensibilização das placas, utilizou-se $50 \mu \mathrm{l}$ de antígeno de $P$. berghei $(20 \mu \mathrm{g} / \mathrm{ml}$ ) (ver item 3.9) diluído em tampão de bicarbonato $\left(\mathrm{NaHCO}_{3}\right) \mathrm{pH} 8,2$. As placas foram incubadas por 18 horas a $4^{0} \mathrm{C}$. Após 3 lavagens sucessivas de 5 minutos cada uma, com PBS contendo 0,05\% de Tween 20 (Sigma Chemical Co.), as placas foram saturadas, por 180 minutos, com $200 \mu \mathrm{l}$ de PBS- contendo $1 \%$ de BSA. Após novas lavagens, adicionou-se a cada orifício da placa $50 \mu \mathrm{l}$ das diluições de cada soro, feitas em PBS-Tween contendo $1 \%$ de BSA (diluições: 1:100 para $\operatorname{lgM} ; 1: 400 \lg 1 ; 1: 800$ de IgG2a) seguida de incubação de 1:30h a temperatura ambiente. Após novos ciclos de lavagem, a presença de anticorpos específicos contra o parasita foi revelada adicionando-se anticorpos de cabra anti-IgM, anti-lgG1 e anti-lgG2a de camundongo conjugados a HRP ("horseradish peroxidase", Southern Biotecnology, USA) (diluída $1 / 2000$ em PBS-Tween com 1\% de BSA) por 1 hora. Por fim, as placas foram lavadas mais uma vez como já descrito, e $100 \mu \mathrm{l}$ do cromógeno TMB (Tetrametilbenzidina, Invitrogen) foi colocado. Aguardou-se 10 minutos e a leitura foi realizada a 650nm em leitor de ELISA MR 5000 (Dynatech). A concentração $(\mu \mathrm{g} / \mathrm{ml})$ de anticorpos IgM, IgG1 e IgG2a foi estimada por padronização indireta descrita por (FERREIRA et al., 1996), com pequenas alterações. Em cada placa de ELISA, alguns dos orifícios foram sensibilizados com soro de cabra anti-imunoglobulina total de camundongo $(10 \mu \mathrm{g} / \mathrm{ml}$ ) e incubados com diluições seriadas (de 250 a 0,056ng/poço, em duplicatas) de um padrão de isotipo de imunoglobulina de camundongo. A correspondência entre os valores de D.O. (Densidade Óptica) e a concentrações de IgM, IgG1 ou IgG2a, foi estabelecida pela equação matemática da parte linear da curva padrão dos isotipos de Imunoglobulinas. As concentrações $(\mu \mathrm{g} / \mathrm{ml})$ de anticorpos parasita-específicos de cada soro foram calculadas aplicando os valores de D.O. nas amostras séricas nesta equação. Todos os anticorpos, incluindo os conjugados e padrões, foram adquiridos de Southern Biotechnologies Associates (Birmingham, USA). 


\subsection{EXPRESSÃO GÊNICA ESPECÍFICA POR MEIO DE qRT-PCR}

Para realização dos ensaios de qRT-PCR, o tecido adiposo, além dos órgãos: pulmão, baço, rim, fígado, cérebro foram congelados em nitrogênio líquido, macerados e armazenados em Trizol a $-80^{\circ} \mathrm{C}$ até a data de processamento. O RNA total foi obtido utilizando o Kit RNeasy Micro ${ }^{\circledR}$ (Qiagen), seguindo o protocolo do fabricante para tecidos e células animais "Animal Cell 1". Um micrograma de RNA total foi convertido em cDNA (TaqMan ${ }^{\circledR}$ Reverse Transcription Reagents, Applied Biosystems) usando primers que amplificam a sequência 5' - CCG ATA ACG AAC GAG ATC TTA ACC TGC TAA TTA GCG GCG AGT ACT CTA TAT CCT TTA TTG GGA GAT TGG TTT TGA CG - 3'. A expressão gênica relativa foi quantificada por qRT-PCR utilizando-se o ensaio Taqman $^{\odot}$ (Applied Biosystems) com sondas específicas para o Plasmodium berghei (Al 38261, PN 4332079). Todos os resultados foram normalizados de acordo com a expressão do gene constitutivo GAPDH e o método quantitativo utilizado foi o $2^{-\Delta C T}$.

\subsection{SEPARAÇÃO DE CÉLULAS (FACS ARIA CELL SORTER ${ }^{\circledR}$ )}

Para 0 isolamento das células dendríticas, $10^{6}$ células do baço de fêmeas crônicas foram enriquecidas com a Miltenyi anti-MHC-II microbeads ${ }^{\circledR}$ (eBiosciences) e passadas em uma coluna magnética. Em seguida, anticorpos monoclonais F4/80 PE-Cy5, CD11c APC, I A (MHC II) PE (BD PharMingen) foram adicionados as células MHC II+. A separação ocorreu dentro de um citômetro de fluxo (FACS ARIA CELL SORTER), onde utilizamos a seguinte estratégia: primeiro fizemos um gate de tamanho por granulosidade (SSC $\times$ FSC) para isolar os leucócitos, depois um gate para MHC classe II e através do dot plot, selecionamos as populações de interesse: macrófagos $\left(\mathrm{F} 4 / 80^{+}\right)$e células dendríticas que foram separadas em tubos contendo soro fetal bovino para manter a viabilidade das mesmas. Em seguida, as células dendríticas $\left(\mathrm{CD} 11 \mathrm{c}^{+}\right)$foram marcadas com o anticorpo anti-CD8, com a finalidade de se obter um perfil das mesmas.

\subsection{ANÁLISE ESTATÍSTICA}

Para análise comparativa entre os grupos experimentais, adotamos o teste Tstudent, ANOVA e Long-rank feitos no programa GraphPad, aplicados de acordo 
com cada situação como citado nas legendas das figuras. Para saber se os grupos são significativamente diferentes ou se os resultados obtidos são frutos de mera flutuação randômica ou acaso, as diferenças entre as amostras foram expressas com média \pm erro padrão da amostra (Média $\pm S E$ ), conforme sugerido por Cumming, G. e colaboradores (2007).Os níveis de significância foram definidos como sendo iguais ou inferiores a $0,05(p<0,05)$. 
Da concepção até o parto, uma variedade de eventos pode elevar a complexidade da gravidez causando a sua interrupção antes do desfecho esperado. Nestes eventos, estão incluídas as infecções por plasmódio, que levam ao desenvolvimento de um quadro inflamatório no tecido placentário, decorrente do sequestro de eritrócitos infectados. Embora, as manifestações clínicas tenham sido descritas, os mecanismos que levam a este quadro ainda não estão bem esclarecidos. Parte deste problema deve-se às limitações intrínsecas aos sistemas experimentais humanos e à acessibilidade ao material biológico nos diferentes estágios da gestação.

Os modelos murinos oferecem a possibilidade de estudo dos mecanismos imunopatológicos envolvidos na recrudescência em condições experimentais definidas e controladas. Recentemente nosso grupo desenvolveu um modelo experimental de recrudescência com animais que possuíam premunição ao plasmódio, utilizando camundongos da linhagem BALB/c infectados com $10^{6}$ eritrócitos parasitados (EP) com o $P$. berghei ANKA ${ }^{\text {GFP }}$ (MARINHO et al., 2009). Este modelo em alguns aspectos reproduz a situação observada em zonas de transmissão instável, onde as gestantes não adquirem níveis importantes de imunidade.

Para estabelecer as condições ideais para realização deste projeto, inicialmente reproduzimos o modelo experimental desenvolvido anteriormente, utilizando animais infectados com $10^{6}$ EP de $P$. berghei ANKA ${ }^{\text {GFP. }}$. Utilizando este inóculo verificamos morte em cerca de $60 \%$ dos animais o que inviabilizaria a continuidade dos experimentos (Fig. 7A). Assim, nosso próximo passo foi testar outros inóculos $\left(10^{5}\right.$ e $\left.10^{4} \mathrm{EP}\right)$. O inóculo de $10^{5} \mathrm{EP}$ também apresentou altos níveis de mortalidade, chegando a 50\%, enquanto que o inóculo de $10^{4} \mathrm{EP}$ apresentou cerca de $10 \%$ de mortalidade (Fig.7B). Por apresentar baixos níveis de mortalidade e não induzir diferenças significativas no perfil de parasitemia (Fig. 7A e B), o inóculo de $10^{4} \mathrm{EP}$ foi escolhido para dar continuidade ao projeto. 
Figura 7. Padronização do inóculo utilizado

A

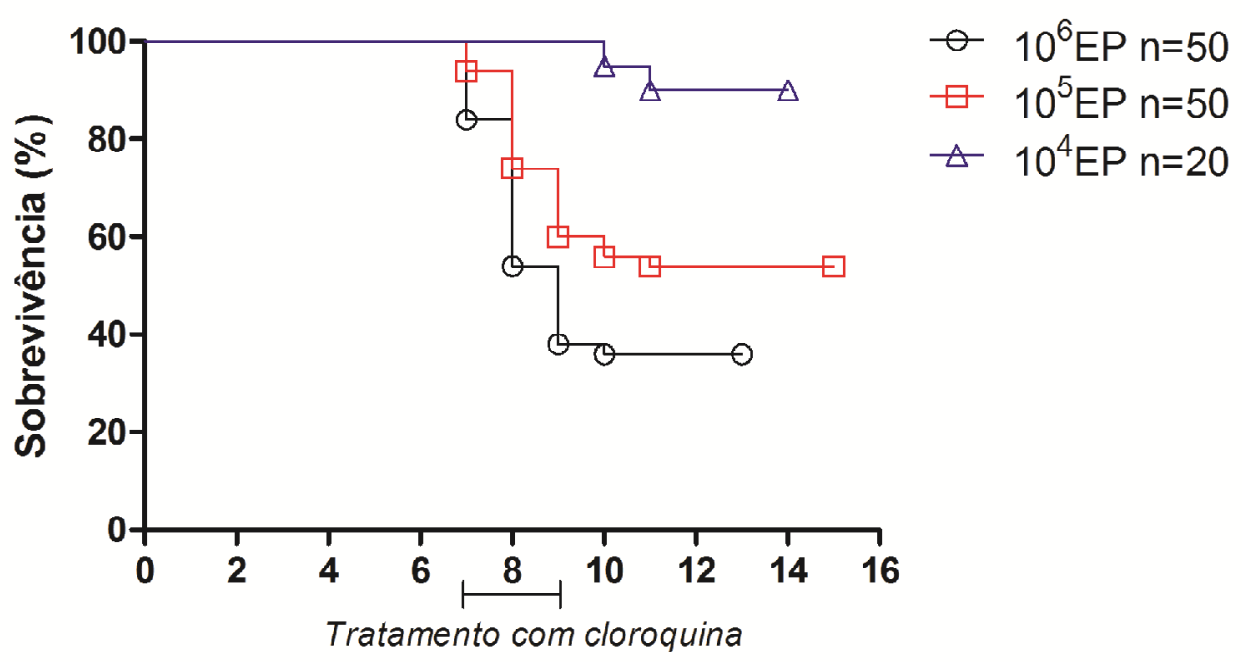

Dias após a infecção

B

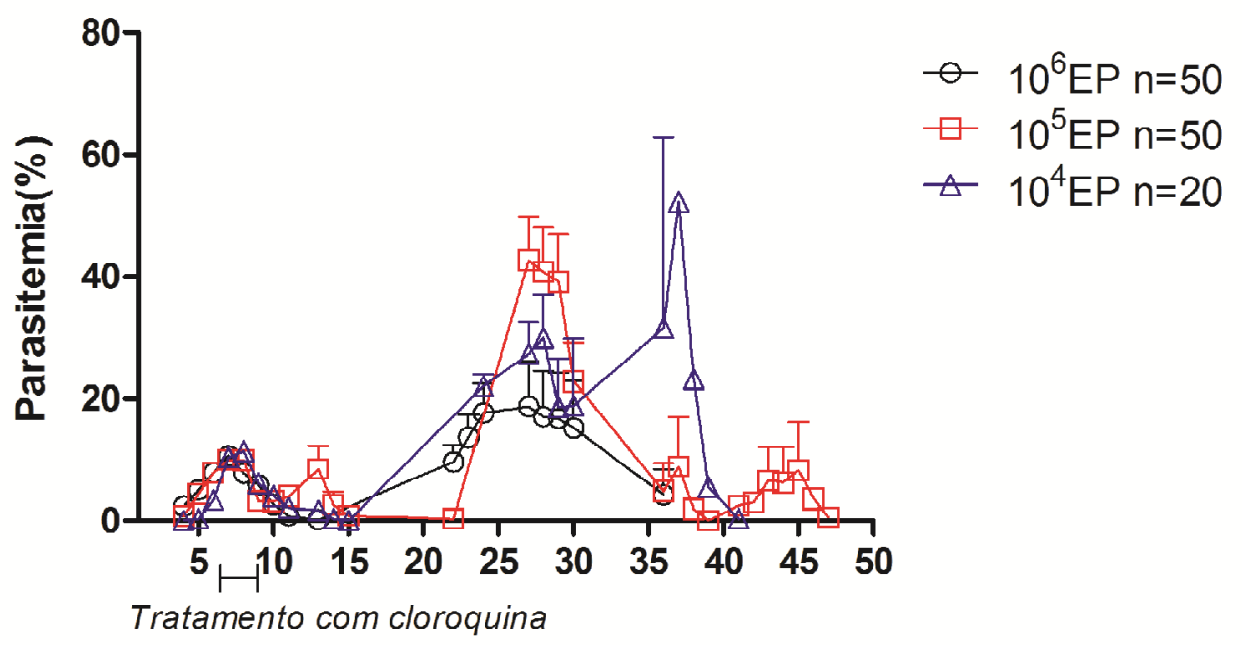

Dias após a infecção

(A) Curva de sobrevivência nos diferentes inóculos indicando que o inóculo $10^{4} \mathrm{EP}$ apresentou menor mortalidade. (B) Curva de parasitemia representativa de fêmeas BALB/c infectadas com $P$. berghei ANKA $^{\text {GFP }}$ (D0) e tratadas com cloroquina por 3 dias $(0,7 \mathrm{mg} /$ dia/animal) com início no D7, nos diferentes inóculos. EP, Eritrócitos Parasitados. Dados expressos como Média $\pm S E$. Log-rank (MantelCox) Test $\mathrm{p}=0,0008$.

Após estabelecermos o inóculo a ser utilizado, o próximo passo foi verificar o efeito da gravidez sobre a infecção. Para tanto, infectamos camundongos BALB/C com $10^{4}$ EP com $P$. berghei ANKA ${ }^{\text {GFP }}$ e sete dias após a infecção, tratamos estes animais durante três dias consecutivos com cloroquina $(0,7 \mathrm{mg} / \mathrm{dia} / \mathrm{animal})$, conforme descrito em material e métodos. Cerca de 40 dias após a infecção, os animais foram 
colocados para acasalar. Nestas condições cerca de $40 \%$ das fêmeas grávidas desenvolvem recrudescência da infecção na primeira gestação (Fig. 8A), apresentando diferentes perfis de parasitemia (Fig. 8B). A análise da curva parasitêmica mostra que os animais apresentaram dois picos de parasitemia nos primeiros 25 dias e, que após este período, verifica-se um controle da infecção, já que não se detecta mais parasitemia periférica. No entanto, ao engravidarem, observa-se o recrudescimento da infecção evidenciado pela presença de um novo pico de parasitemia.

\section{Figura 8. Recrudescência da malária associada à gravidez}

\section{A}

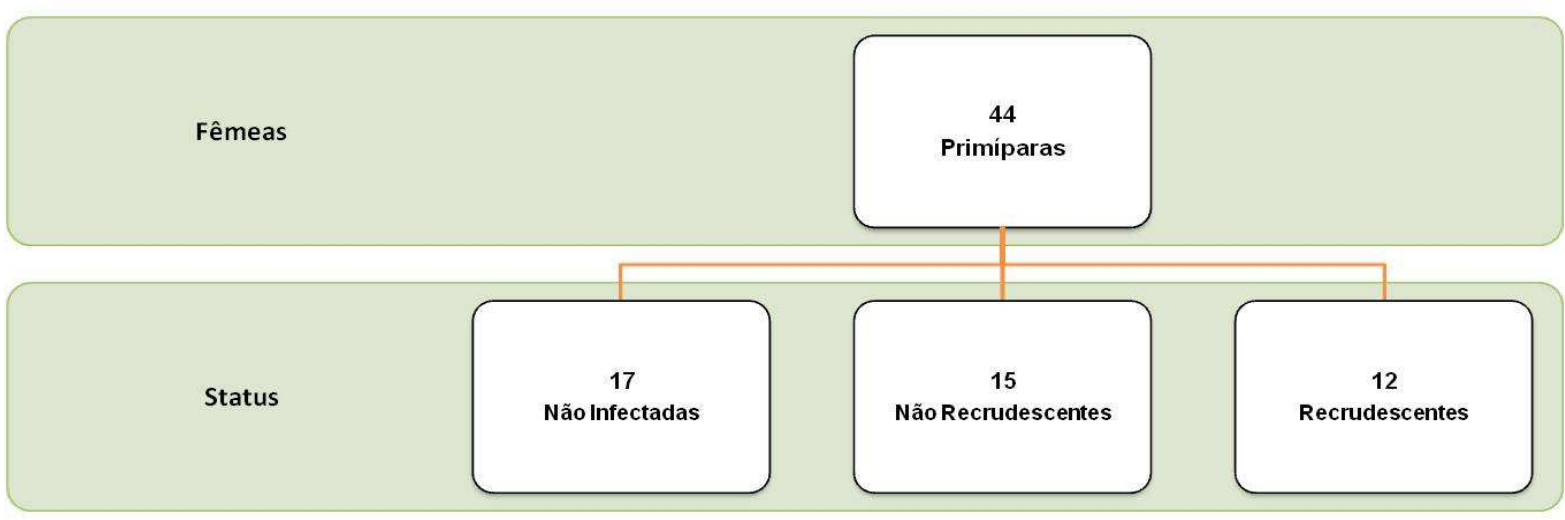

B

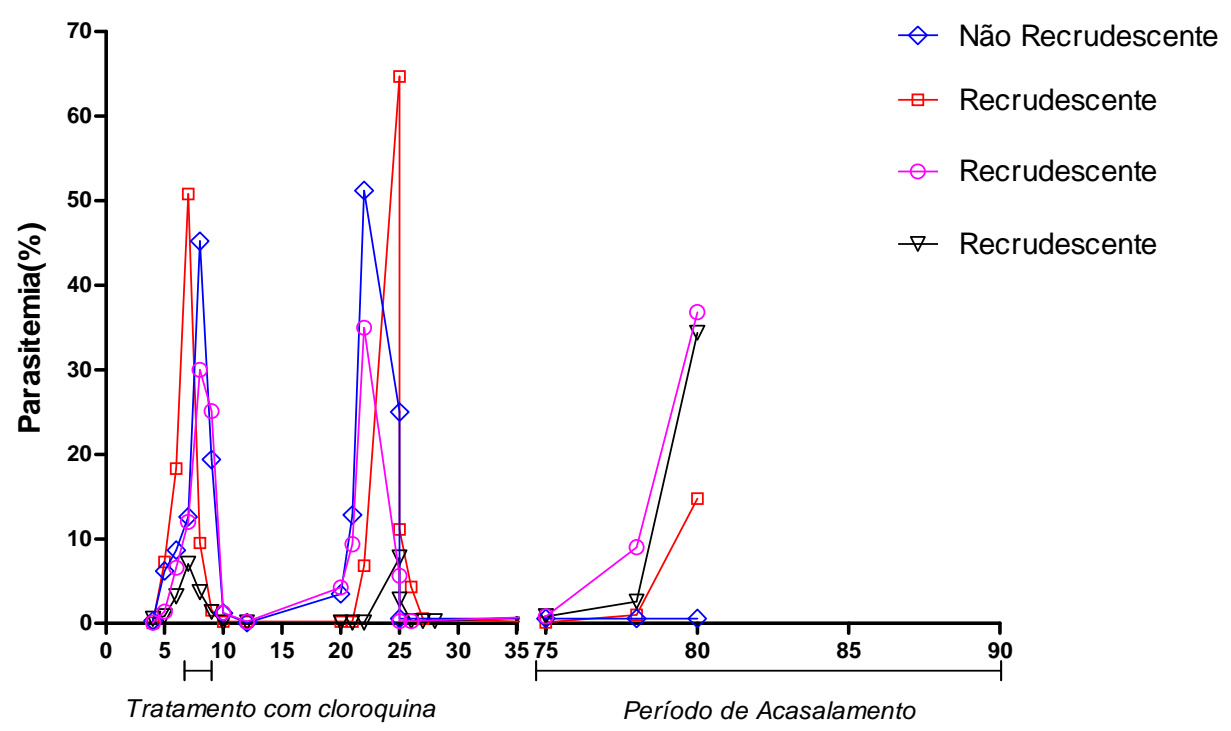

Dias após a infecção

(A) Organograma representativo do número de animais utilizados nos experimentos. (B) Curva de parasitemia representativa de quatro fêmeas BALB/c infectadas com $P$. berghei ANKA GFP (D0) e tratadas com cloroquina por 3 dias $(0,7 \mathrm{mg} /$ dia/animal) com início no dia 7 (D7). O gráfico mostra três primigrávidas recrudescentes e uma não recrudescente com inóculo de $10^{4} \mathrm{EP}$. 
Nossa próxima pergunta foi saber se a parasitemia em fêmeas recrudescentes tem correlação com a patologia placentária. Para isso, fizemos a análise morfométrica de cortes de placenta. Como mostrado na figura 9A, observase que quanto maior a parasitemia periférica, maior a redução do espaço vascular. Além disso, as fêmeas primíparas recrudescentes apresentam uma redução no espaço vascular placentário quando comparadas tanto com as primíparas controle não infectadas, quanto com fêmeas primíparas que não recrudesceram. Em adição, fêmeas não recrudescentes apresentam uma redução deste espaço quando comparadas com controle não infectadas (Fig. 9).

Alterações fisiológicas desencadeadas pela gestação podem modificar o status imunológico do animal e consequentemente serem responsável pelo recrudescimento da infecção. Dado que o baço e a placenta são compartimentos essenciais na patofisiologia da PM, nosso próximo passo foi estudar as diferenças celulares nestes órgãos comparando animais infectados e não infectados.

A análise do perfil celular do baço mostra que os animais infectados, recrudescentes ou não, apresentaram aumento em relação aos animais controle, tanto de peso $(1,19 \mathrm{~g} \pm 0,51$ e $0,307 \mathrm{~g} \pm 0,103$ vs $0,144 \mathrm{~g} \pm 0,02$ recrudescentes e não recrudescentes vs controle, respectivamente) quanto de número de células $\left(397,5 \pm 110,9 \times 10^{6}, 203,6 \pm 74,67 \times 10^{6}\right.$ vs $89,30 \pm 17,95 \times 10^{6}$ recrudescentes e não recrudescentes vs controle, respectivamente) (Fig.10).

A análise do número absoluto das populações mostra que células T $\mathrm{CD}^{+}$, células B $\left(C D 19^{+}\right)$e TCR $\gamma \delta$ estão elevadas no baço dos animais com recrudescência (Fig. 11A). Para avaliar se a carga parasitária influencia na resposta imune e no número das populações celulares, dividimos as fêmeas recrudescentes em dois grupos: baixa parasitemia (até $5 \%$ de parasitemia periférica no G19) e alta parasitemia (acima de 5\% de parasitemia periférica no G19). Comparando-se os dois grupos de fêmeas recrudescentes, houve diferença no número absoluto de células T CD4+ (Fig. 11B). 


\section{Figura 9. Redução do espaço vascular em gestantes com recrudescência}

A

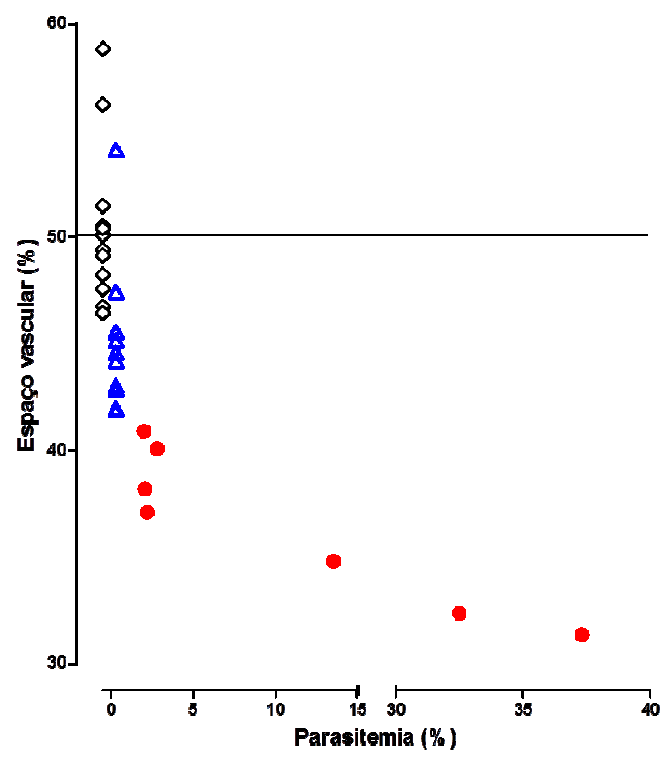

- Controle $(n=13) \Delta$ Năo Recrudescente $(n=11)$ - Recrudescente $(n=7)$

B
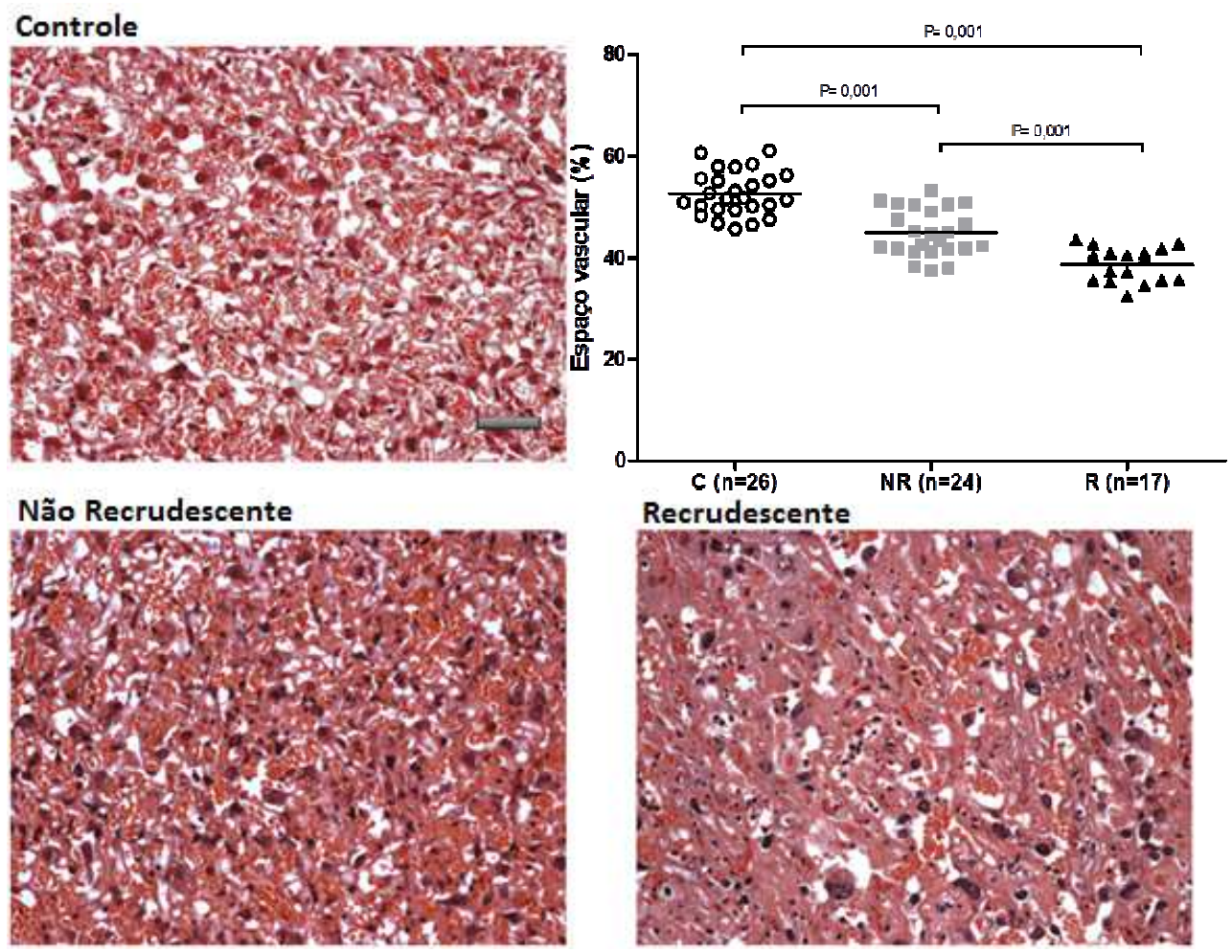

Camundongos fêmeas BALB/c foram infectados i.p. com $10^{4}$ EP com P. berghei ANKA ${ }^{\text {GFP }}$, depois do tratamento colocadas para acasalar e sacrificados em G19. (A) Em fêmeas recrudescentes, a parasitemia foi correlacionada com a redução do espaço vascular (coeficiente de correlação para as fêmeas recrudescentes é $\left.r^{2}=0,8545, P=0,0029\right) n=$ número de animais. (B) Observa-se a redução da área vascular das placentas dos animais recrudescentes quando comparados com animais não recrudescentes e controle não infectado, $\mathrm{n}=$ número de placentas. Barra de escala, $50 \mu \mathrm{m}$. As áreas sinusoidais da placenta foram quantificadas em relação à área total da placenta utilizando-se um método automatizado de avaliação morfométrica, como descrito em Materiais e Métodos ( $\mathrm{P}$ value $=0,001$, Teste One Way ANOVA). C, controle; NR, não recrudescente e R, recrudescente. 
Figura 10. Peso do baço e número total de células
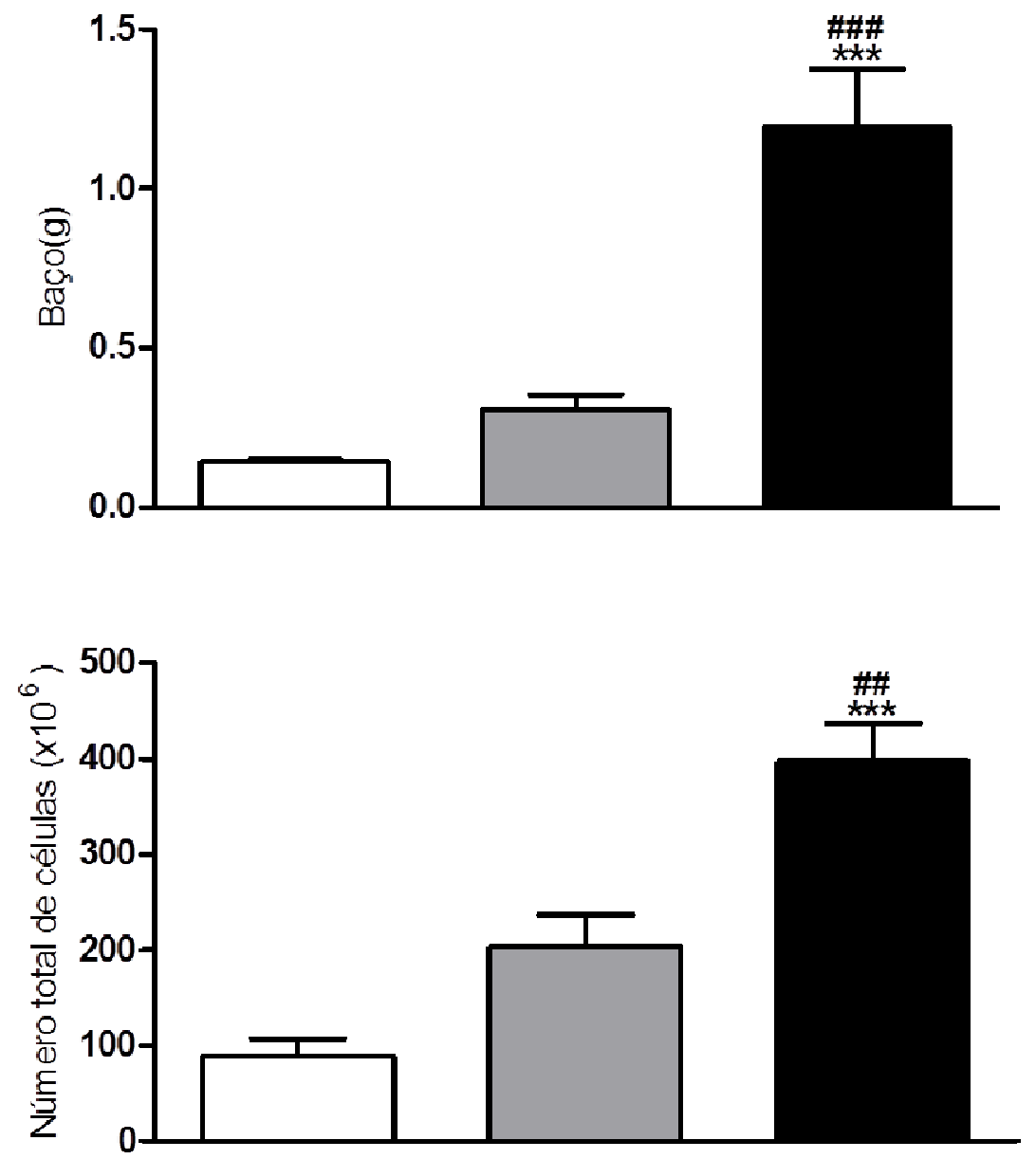

$\square$ Controle $(n=8) \square$ Não Recrudescente $(n=5) \square$ Recrudescente $(n=8)$

No dia 19 de gestação (G19) os animais foram eutanaziados e os baços foram retirados e processados. Dados expressos como Média $\pm S D\left({ }^{* * *} p<0,001\right.$ em relação ao controle; \#\#p $<0,01$ em relação a não recrudescente; \#\#\#p <0,001 em relação a não recrudescente). 
Para verificar o perfil de ativação das diferentes populações celulares do baço durante a recrudescência, analisamos os marcadores de ativação CD69, CD62L e CD86. Dentre as populações estudadas, a população de TCD4 ${ }^{+}$apresentou maior perfil de ativação caracterizado por um aumento na expressão de CD69 e diminuição na expressão de CD62L (L-selectina) (Fig. 12B). Em relação às células $T C D 8^{+}$, estas apresentaram maior expressão de CD69 e uma tendência à diminuição na expressão de CD62L. Além disso, estudamos o perfil de ativação dos macrófagos presentes no baço. Para tanto, verificamos a expressão de CD86, uma importante molécula presente em células apresentadoras de antígeno e que está envolvida na geração de sinais co-estimulatórios para ativação e sobrevivência das células $T$. Os resultados da figura 12B mostram que estas células apresentam expressão diminuída de CD86 nos animais infectados quando comparados com os controles. A comparação entre os grupos recrudescentes (alta vs. baixa parasitemia), não apresentou diferenças na expressão deste marcador (Fig. 12C).

O próximo passo foi estudar os mesmos marcadores nas células da placenta. Como observado na figura 13, embora não tenham sido observadas diferenças significativas entre os animais infectados e os controles, nota-se uma tendência à diminuição do número células por placenta nos grupos infectados quando comparados com o controle (Fig. 13).

Analisando o perfil leucocitário de placentas, pode-se verificar no grupo que apresentou recrudescência uma tendência à diminuição do número total de células de todas as populações estudadas (Fig. 14A). Realizando a comparação entre os grupos recrudescentes (alta vs. baixa parasitemia), não observamos diferenças significativas entre eles (Fig. 14B). Para análise do perfil de ativação dos leucócitos placentários, usamos os mesmos marcadores descritos anteriormente para as células do baço. Como mostrado na figura 15, observamos uma tendência de maior ativação das células nas fêmeas recrudescentes na maioria das populações analisadas. No entanto, diferente do observado na outras populações, as células $\mathrm{TCD}^{+}$apresentaram um aumento no perfil de ativação quando comparadas com os grupos controle e não recrudescentes (Fig. 15B). 
Figura 11. Análise por citometria de fluxo do número de células esplênicas

A
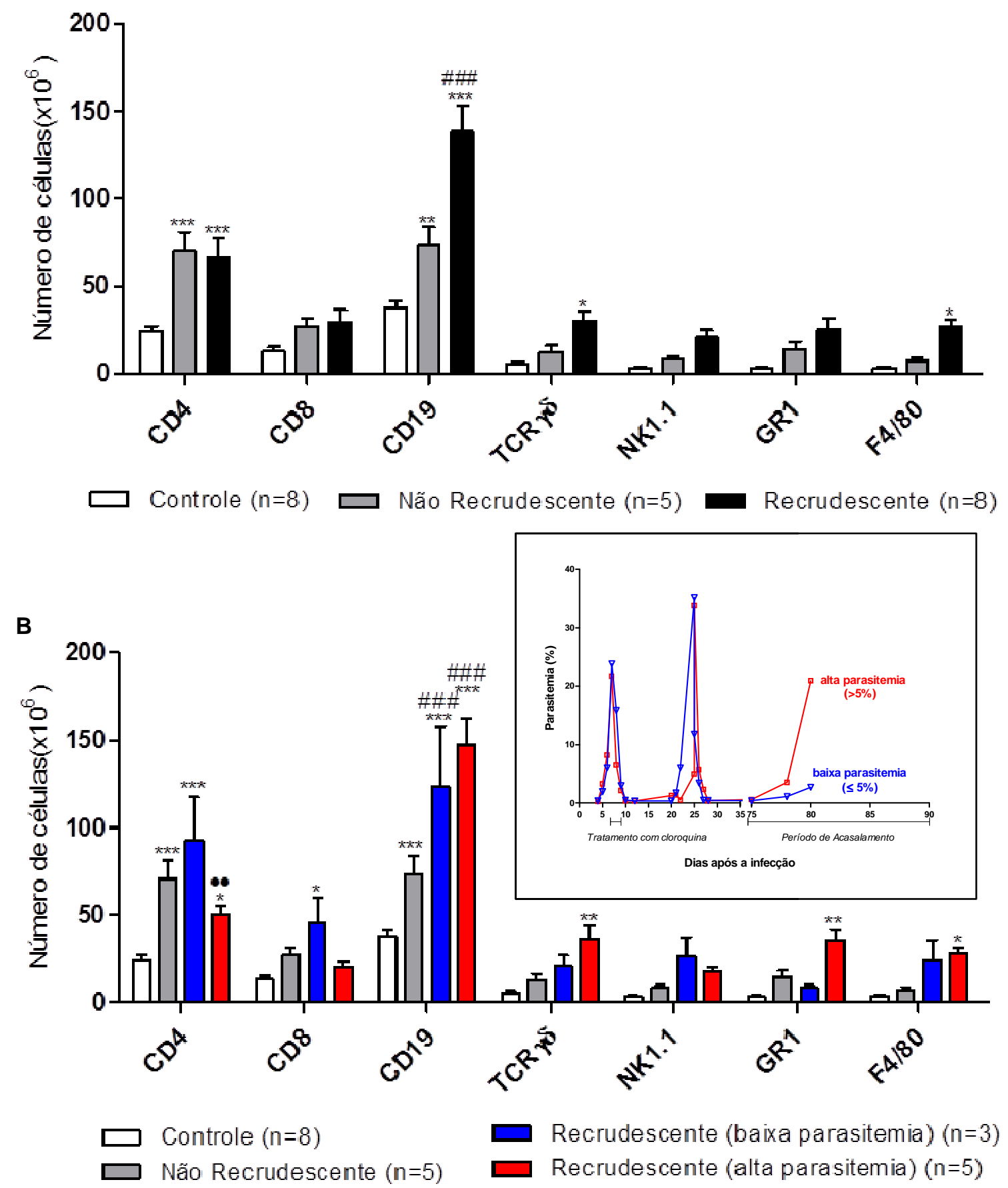

(A) Número de células de fêmeas controle não infectadas, fêmeas infectadas não recrudescentes e recrudescentes foram marcadas com diferentes anticorpos. (B) Fêmeas recrudescentes foram divididas conforme a carga parasitária (baixa e alta parasitemia periférica). Dados expressos como Média $\pm S E\left({ }^{*} p<0,05\right.$ em relação ao controle; ${ }^{* *} p<0,01$ em relação ao controle; ${ }^{* \star *} p<0,001$ em relação ao controle; $\# p<0,05$ em relação não recrudescente; \#\#\#p<0,001 em relação a não recrudescente; $\bullet \bullet p<0,01$ em relação a recrudescente de baixa parasitemia. 
Figura 12. Análise de marcadores de ativação no baço por citometria de fluxo

A
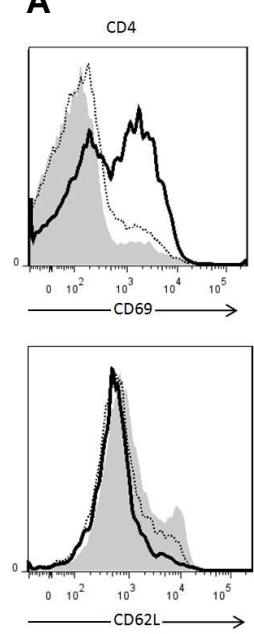

$\square$ Controle
CD8
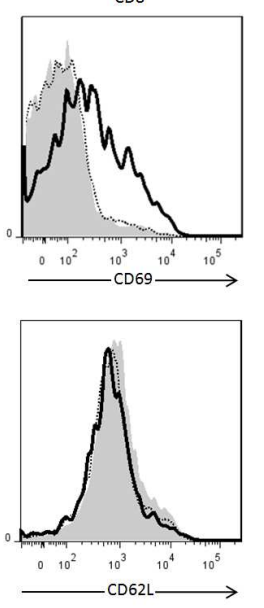

Não Recrudescente
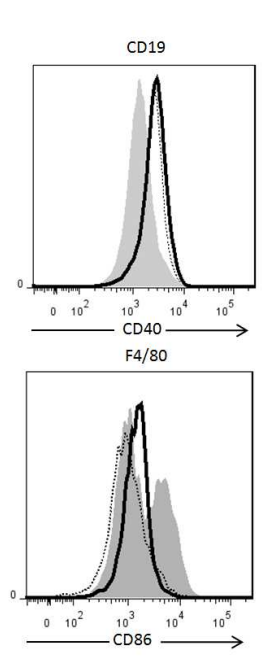

Recrudescente
B

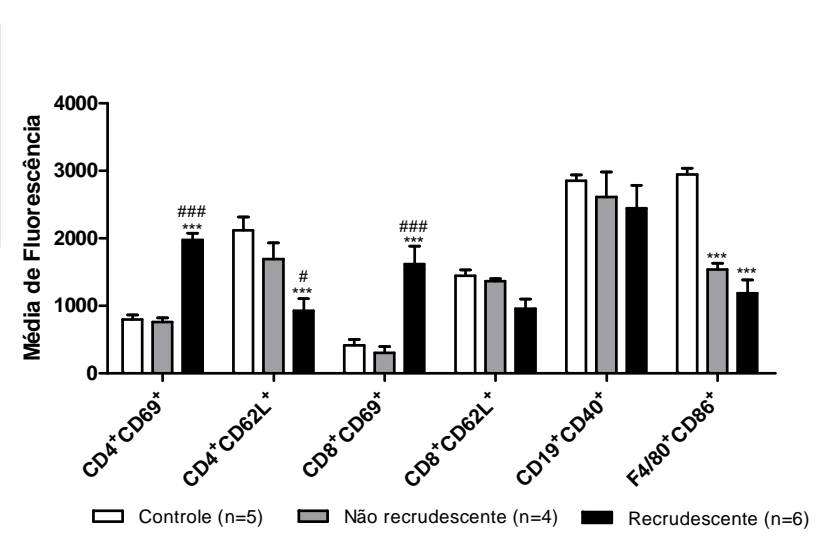

B
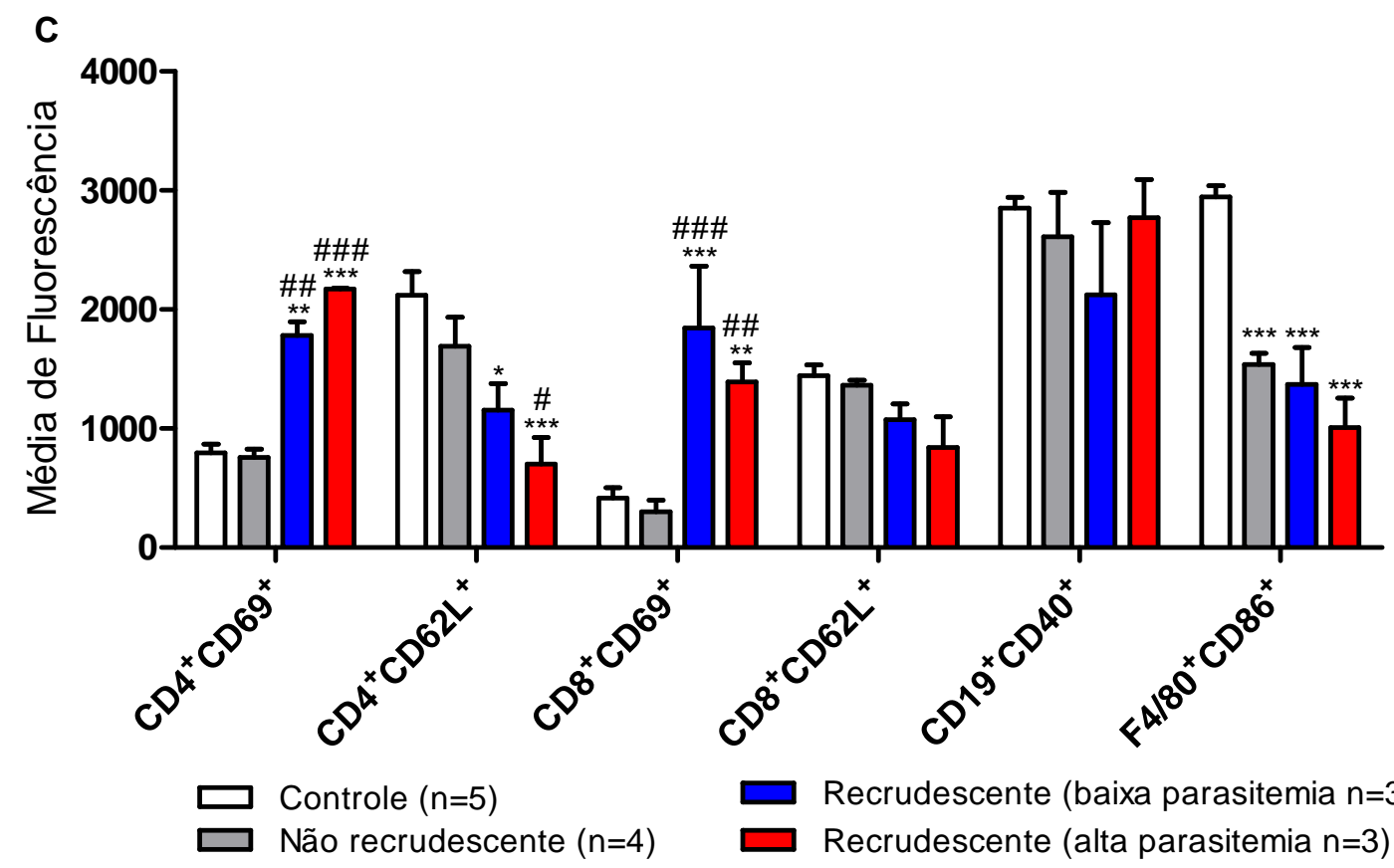

Recrudescente (baixa parasitemia $n=3$ )

Recrudescente (alta parasitemia $\mathrm{n}=3$ )

Células do baço de fêmeas controle não infectadas, fêmeas infectadas não recrudescentes e recrudescentes foram marcadas com diferentes anticorpos (anti CD4, CD8, CD69, CD62L, CD19, CD40, f4/80 e CD86) com a finalidade de se determinar os marcadores de ativação envolvidos na recrudescência. (A) Histograma representativo de células de animais recrudescentes (linha grossa), não recrudescentes (linha pontilhada) e animais controle (histogramas sólidos). (B) Média da fluorescência dos marcadores de ativação. (C) Média de fluorescência dos marcadores de ativação onde fêmeas recrudescentes foram divididas conforme a carga parasitária (baixa e alta parasitemia periférica). Dados expressos como Média $\pm S E\left({ }^{*} p<0,05\right.$ em relação ao controle; ${ }^{* *} p<0,01$ em relação ao controle; ${ }^{* *} p<0,001$ em relação ao controle; $\# p<0,05$ em relação não recrudescente; \#\#p $<0,01$ em relação a não recrudescente; \#\#\#p<0,001 em relação a não recrudescente). 
Figura 13. Peso da placenta e número total de células
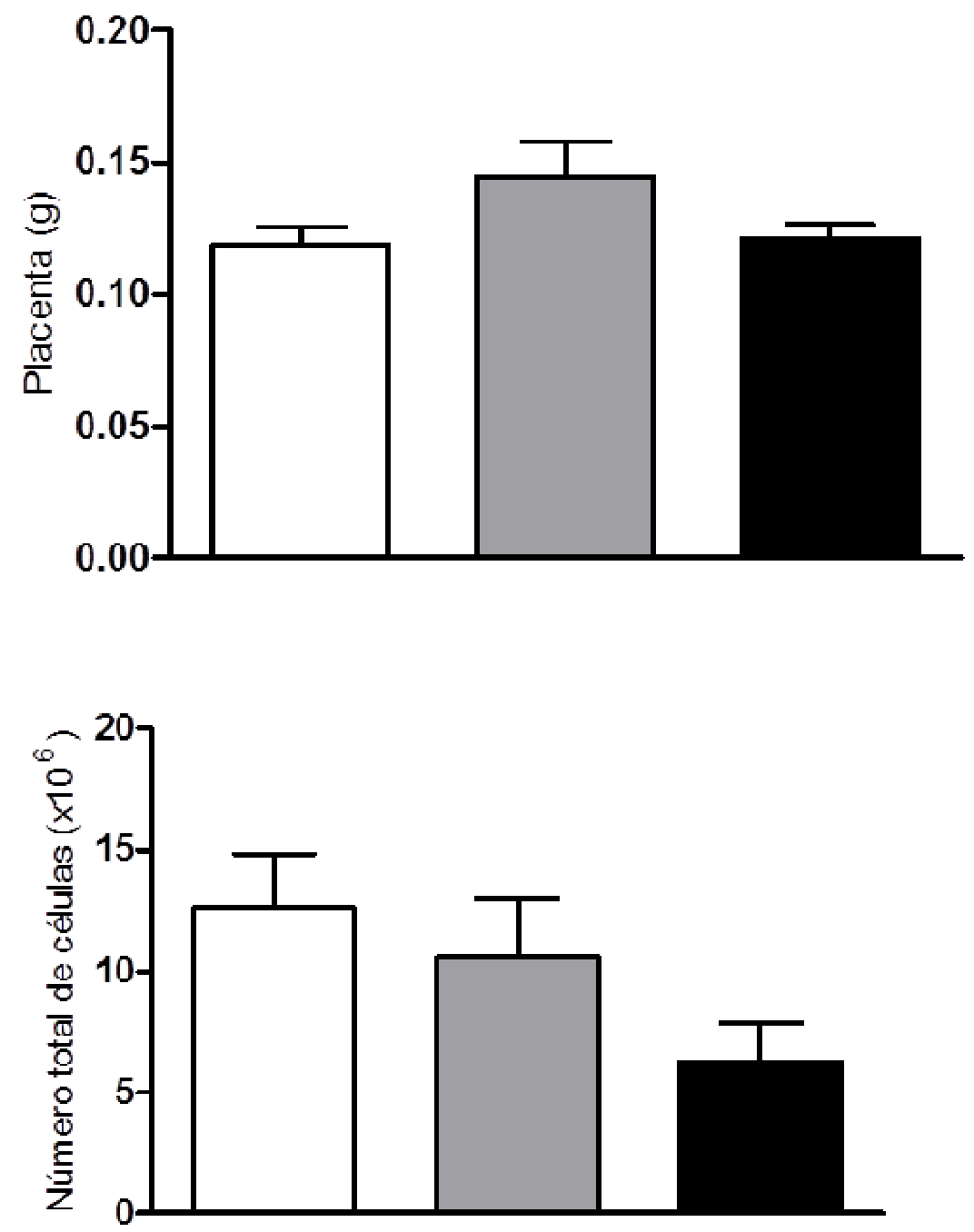

$\square$ Controle $(n=8) \square$ Não Recrudescente $(n=5) \square$ Recrudescente $(n=8)$

No dia 19 de gestação (G19) os animais foram eutanaziados e as placentas foram retiradas e processadas. Dados expressos como Média $\pm S D$. Não foram observadas diferenças estatísticas significativas. 
Figura 14. Análise por citometria de fluxo do número de células da placenta
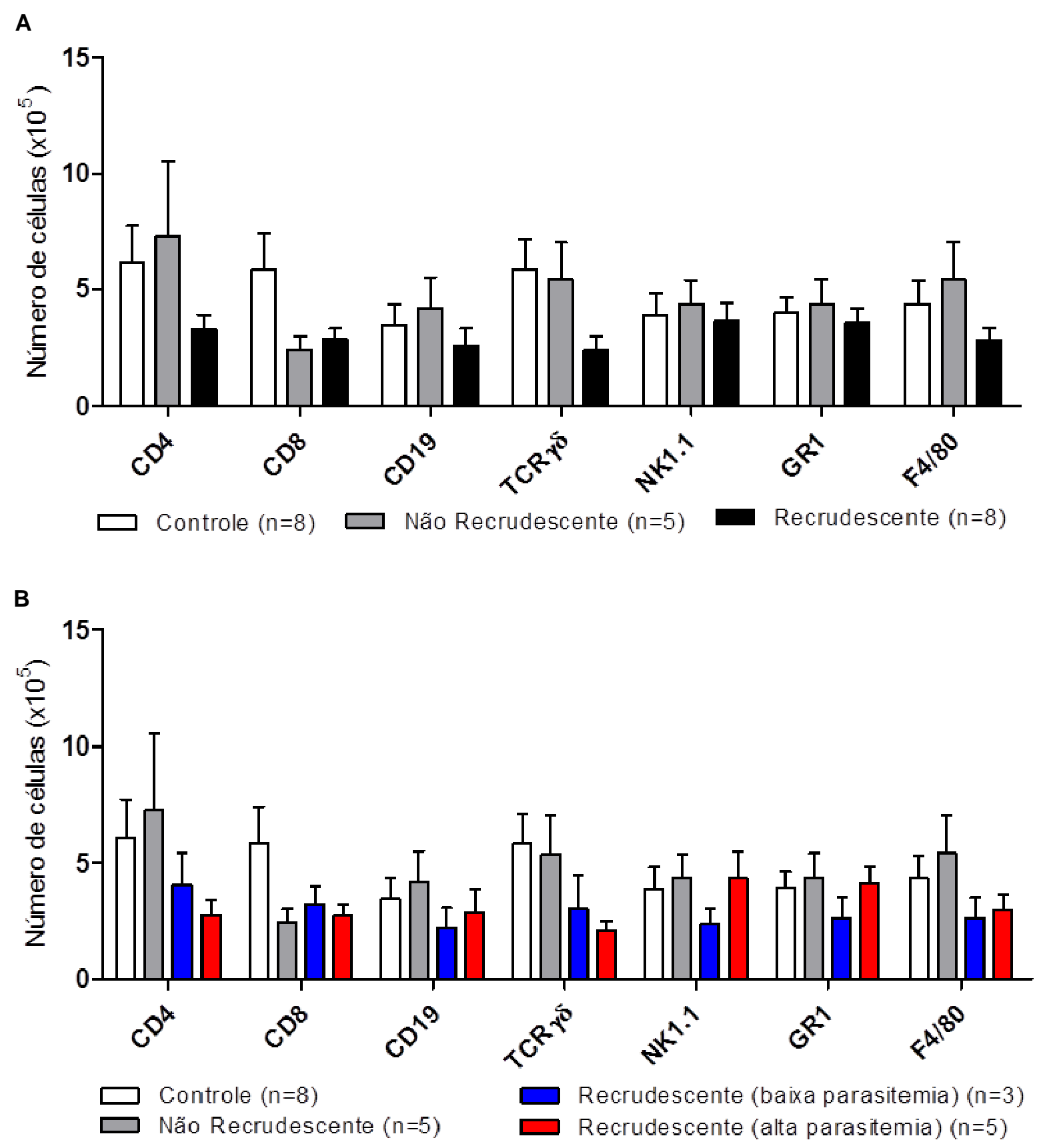

(A) Número de células de fêmeas controle não infectadas e das fêmeas infectadas não recrudescentes e recrudescentes extraídas e marcadas com diferentes anticorpos. (B) Fêmeas recrudescentes foram divididas conforme a carga parasitária (baixa e alta parasitemia periférica). Dados expressos como Média $\pm S E$. Foi feito análise estatística, porém não houve diferenças significativas. 
Figura 15. Análise de marcadores de ativação na placenta por citometria de fluxo
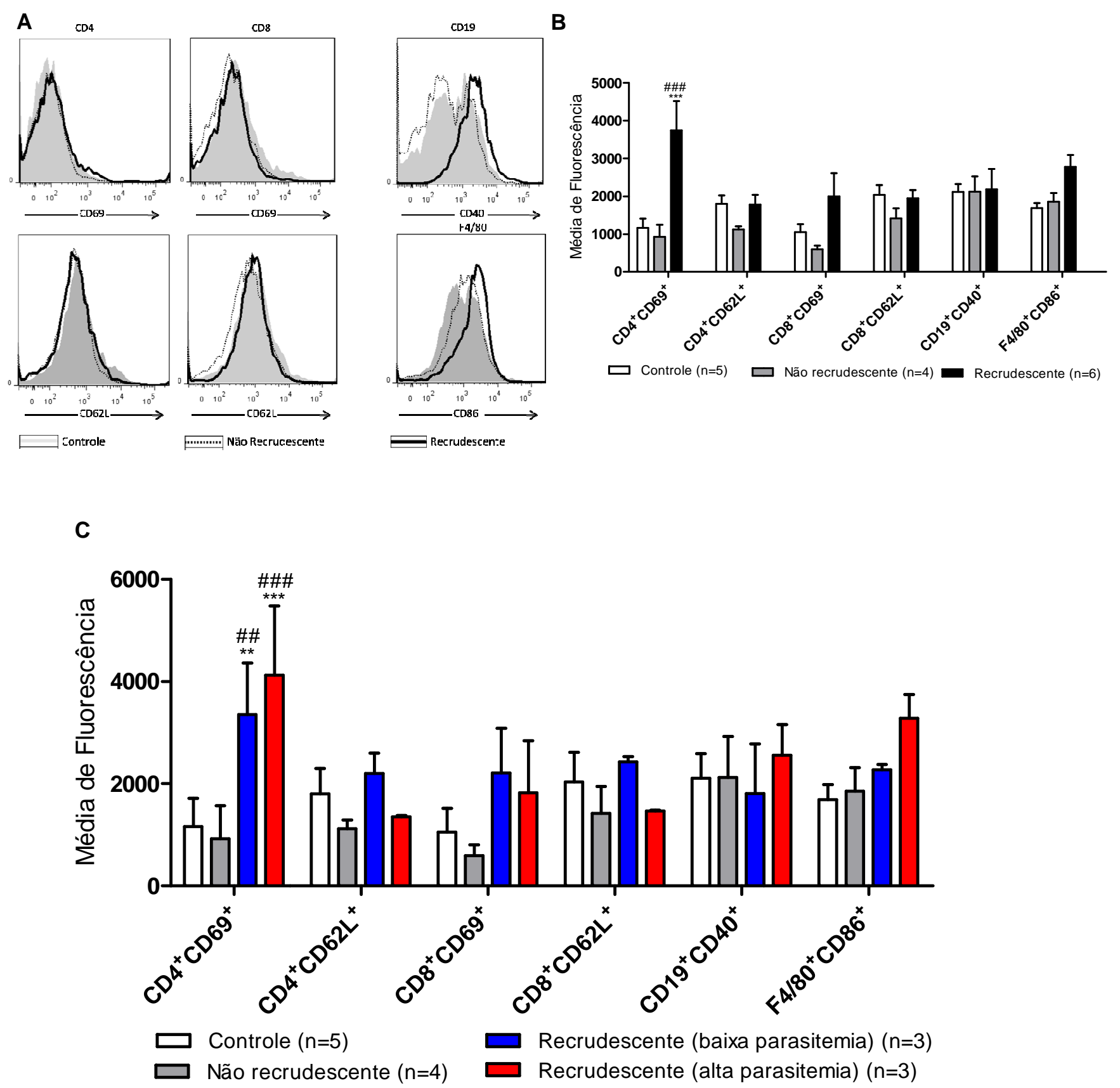

Células da placenta de fêmeas controle não infectadas, fêmeas infectadas não recrudescentes e recrudescentes foram marcadas com diferentes anticorpos (anti CD4, CD8, CD69, CD62L, CD19, CD40, $\mathrm{f} 4 / 80$ e CD86) com a finalidade de se determinar os marcadores de ativação envolvidos na recrudescência. (ver materiais e métodos). (A) Histograma representativo de células de animais recrudescentes (linha grossa), não recrudescentes (linha pontilhada) e animais controle (histogramas sólidos). (B) Média da fluorescência dos marcadores de ativação. (C) Média de fluorescência dos marcadores de ativação onde fêmeas recrudescentes foram divididas conforme a carga parasitária (baixa e alta parasitemia periférica). Dados expressos como Média $\pm S E\left({ }^{* *} \mathrm{p}<0,01 \mathrm{em}\right.$ relação ao controle; ${ }^{* * *} p<0,001$ em relação ao controle; \#\#p<0,01 em relação não recrudescente; \#\#\#p<0,001 em relação a não recrudescente). 
Dado que a imunidade adquirida estaria diretamente relacionada com 0 controle da infecção na recrudescência e que a produção de citocinas é um importante parâmetro para avaliar o padrão imunológico associado com a infecção, nosso próximo passo foi obter um perfil de citocinas das fêmeas controle, recrudescentes ou não, determinando citocinas séricas relacionadas aos fenótipos Th1 (IL-6, IFN- $\gamma$, TNF- $\alpha$ ), Th2 (IL-2, IL-4, IL-10) e Th17 (IL-17). Como mostrado na figura 16, observa-se aumento de TNF- $\alpha$ e uma tendência de aumento de IL-6 nas fêmeas recrudescentes. Em relação a IL-10, tanto as fêmeas recrudescentes quanto as não recrudescentes apresentaram aumento em relação ao controle (Fig. 16A). No entanto, quando comparados recrudescentes e não recrudescentes, observamos uma maior produção de IL-10, cerca de 3 vezes mais, no grupo não recrudescente.

Como as citocinas que apresentaram diferenças significativas foram TNF- $\alpha$ e IL-10 realizamos uma comparação entre os grupos recrudescentes, onde não observamos diferenças significativas entre eles, entretanto houve um aumento de TNF- $\alpha$ em fêmeas recrudescentes com alta parasitemia (Fig. 16B). Não foram observados níveis detectáveis de IL-2 em nenhum dos grupos analisados.

Com a finalidade de compreendermos se a resposta de anticorpos anti $P$. berghei está correlacionada com a recrudescência durante a gestação, determinamos os títulos de anticorpos lgM e lgG específicos ao parasita. Além disso, analisamos as subclasses de $\lg G$ (IgG1 e IgG2a). Nossos resultados mostram que entre os grupos imunes, não há diferença entre as concentrações dos anticorpos analisados (Fig. 17). No entanto, quando comparamos as fêmeas não recrudescentes (imunes e grávidas) e as recrudescentes (imunes e grávidas) não encontramos diferenças entre os títulos de IgG1 (Fig. 17A). O mesmo padrão de resultado foi observado com relação à IgG2a. Além disso, entre as grávidas houve apenas um discreto aumento de IgG2a nas fêmeas que recrudescem (Fig. 17B). A relação IgG2a por IgG1 indica que a quantidade de lgG2a é cerca de 3 vezes a de IgG1 (Fig. 17C). Em adição, houve aumento significativo entre as grávidas recrudescentes e não recrudescentes nos títulos de lgM (Fig. 17D). 
Figura 16. Quantificação de citocinas séricas

A

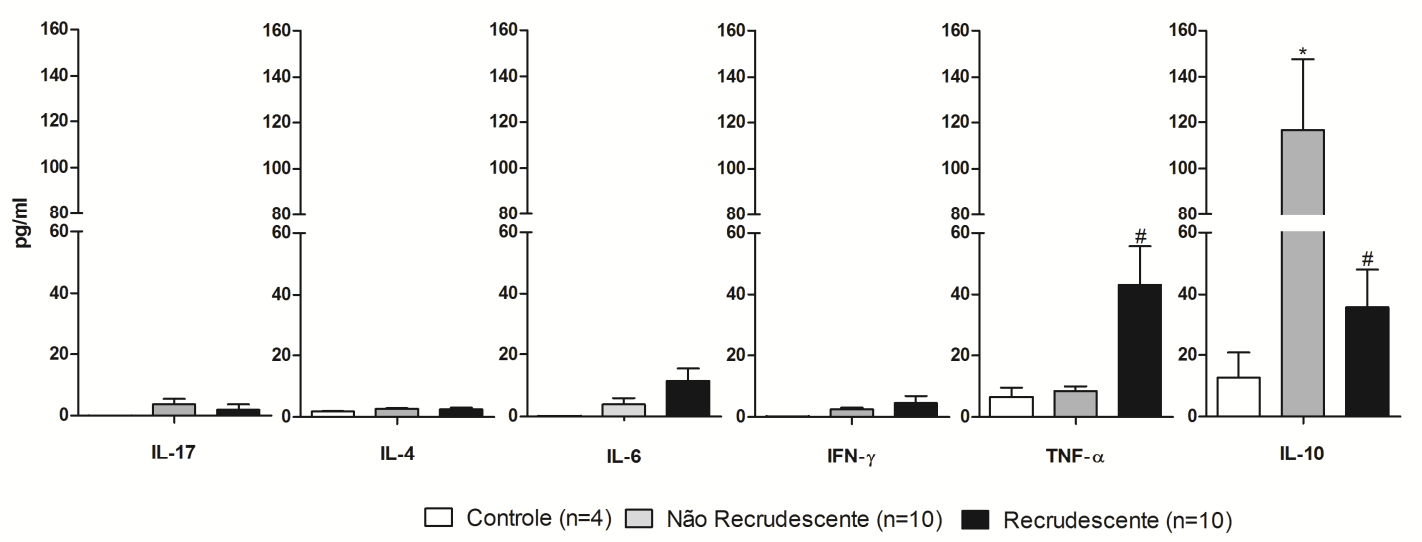

B

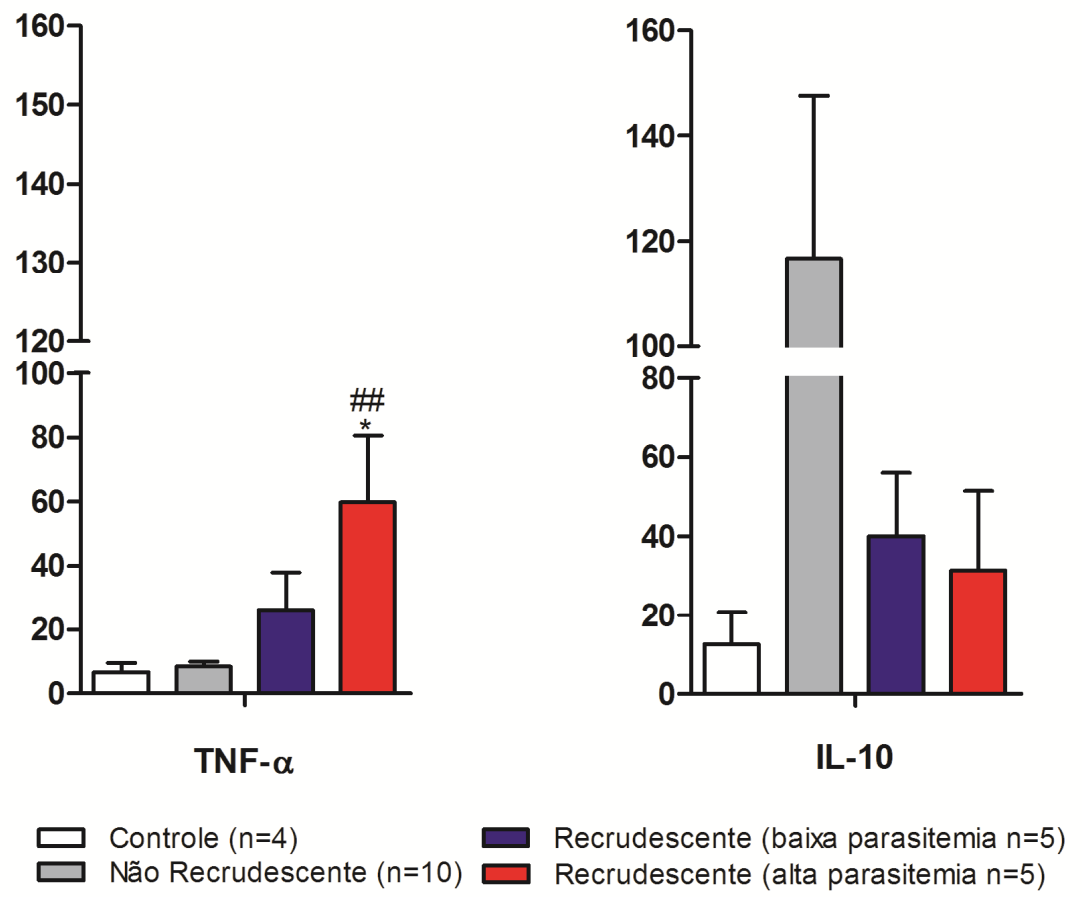

Quantificação de citocinas séricas relacionadas aos fenótipos Th1, Th2 e Th17 pelo kit CBA. (A) Média da concentração de citocinas em $\mathrm{pg} / \mathrm{ml}$ de fêmeas controle, não recrudescentes e recrudescentes. (B) Média da concentração de citocinas TNF- $\alpha$ e IL-10 em fêmeas recrudescentes dividas conforme a carga parasitária (baixa e alta parasitemia periférica). Dados expressos como Média $\pm S E$. ( ${ }^{*} p<0,05$ em relação ao controle; $\# p<0,05$ em relação não recrudescente; \#\#p<0,01 em relação a não recrudescente). 
Figura 17. Determinação de anticorpos específicos para Plasmodium berghei

A

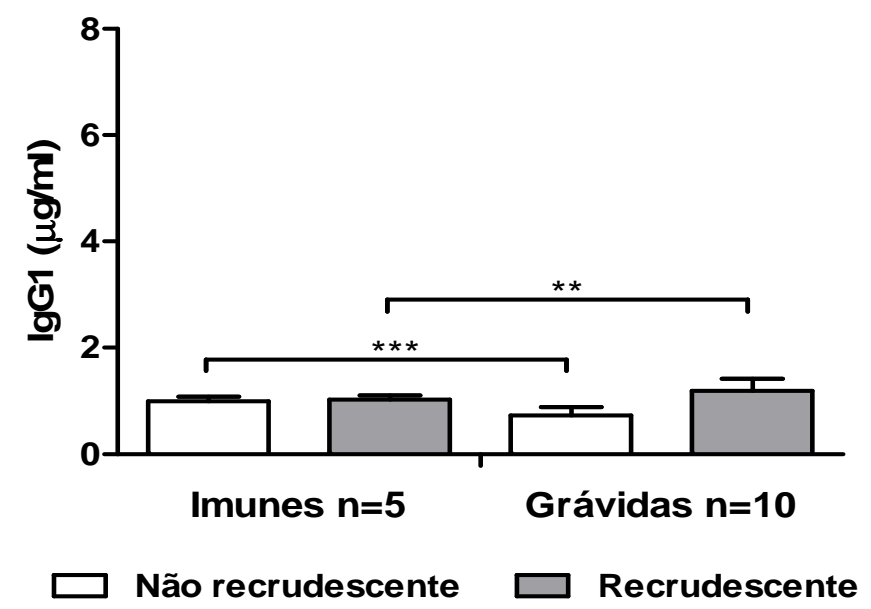

C

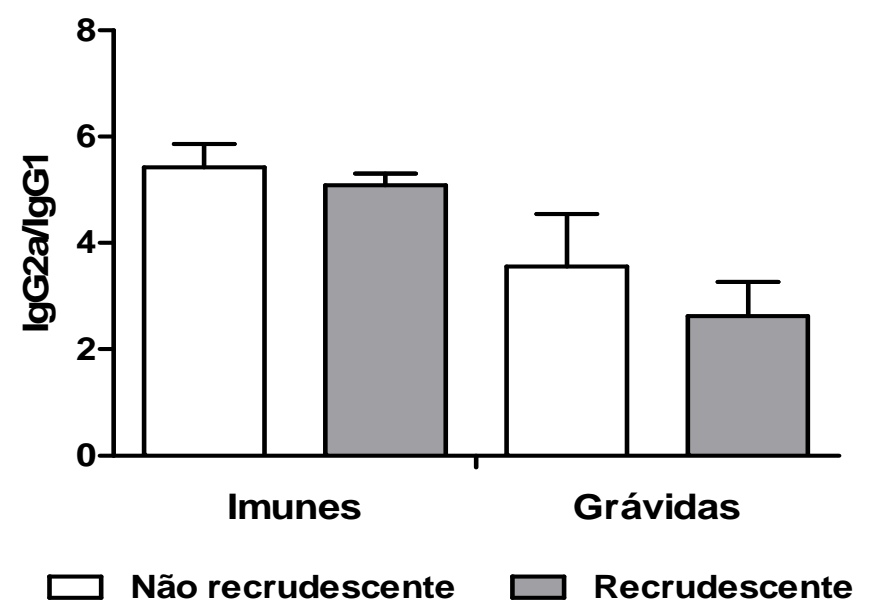

B

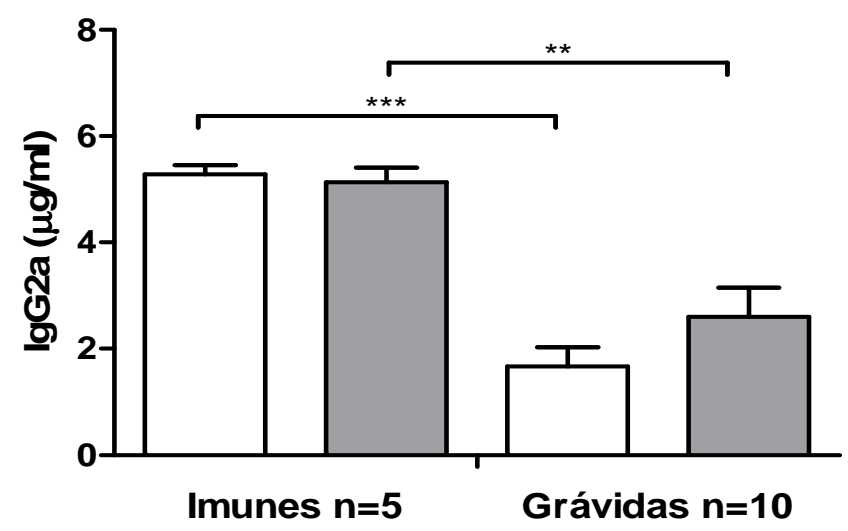

$\square$ Não recrudescente $\square$ Recrudescente

D

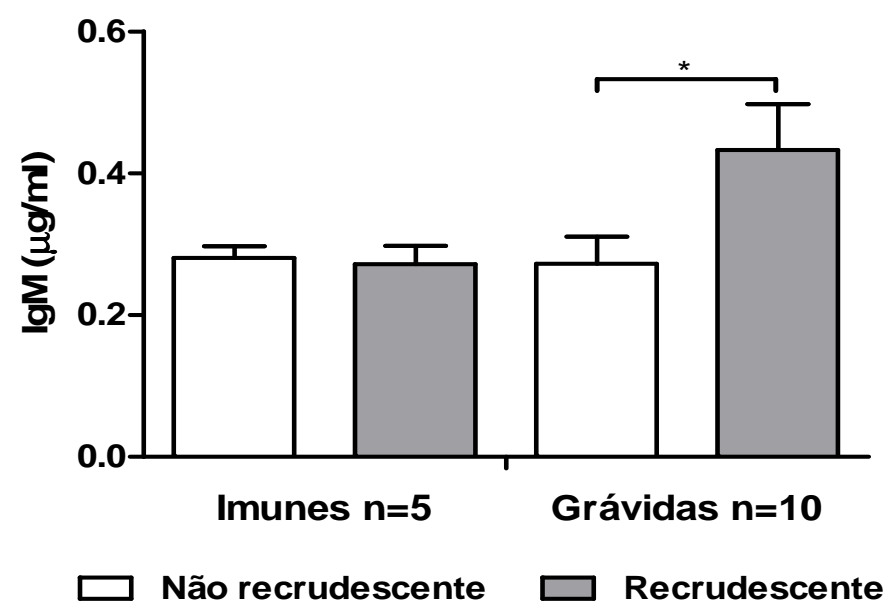

$\lg$ M e isotipos de IgG anti- $P$. berghei em amostras de soro de fêmeas imunes, coletadas após 14 dias do $2^{\circ}$ pico de infecção, e de grávidas recrudescentes ou não, coletadas durante a cesárea no G19. Dados expressos como Média $\pm S E\left({ }^{*} p<0,05,{ }^{* *} p<0,01 e^{* * *} p<0,001\right)$. 
Em áreas de alta transmissão, a taxa de inoculação é superior a 10 picadas por ano e as mulheres apresentam um alto grau de imunidade, principalmente títulos de anticorpos específicos que atuam no bloqueio da adesão de eritrócitos parasitados à placenta. Com isso, tentamos reproduzir em nosso modelo estas regiões a fim de verificar se há correlação entre os níveis de anticorpos e recrudescência. Assim, infectamos e tratamos os animais com cloroquina conforme descrito no material e métodos (ítem 3.2); e após duas semanas do aparecimento do segundo pico de parasitemia periférica, coletamos o soro e fizemos o primeiro desafio, utilizando a mesma carga parasitária da primeira infecção $\left(10^{4}\right.$ EP de $P$. berghei ANKA ${ }^{\text {GFP }}$ ). Duas semanas após o primeiro desafio, nova amostra de soro foi coletada e foi feito novo desafio nas mesmas condições que o primeiro (Fig. 18A). Nossos resultados demonstram uma diminuição da parasitemia periférica após $01^{\circ}$ desafio quando comparada com a infecção. Após o $2^{0}$ desafio verificamos uma diminuição da parasitemia quando comparada com o 10 desafio (Fig. 18B). Em relação as concentrações dos anticorpos, observamos um aumento significativo de IgG1 e IgG2a nos animais desafiados, sendo que estas concentrações são maiores no $2^{\circ}$ desafio em ambas sub-classes (Fig. 18C). A taxa IgG2a por IgG1 indica um aumento de IgG2a (Fig. 18C). As fêmeas foram colocadas para acasalar, houve $43 \%$ de gravidez entre as fêmeas, entretanto não houve recrudescência. 
Figura 18. Curva de parasitemia e determinação de anticorpos específicos para Plasmodium berghei em animais desafiados

A

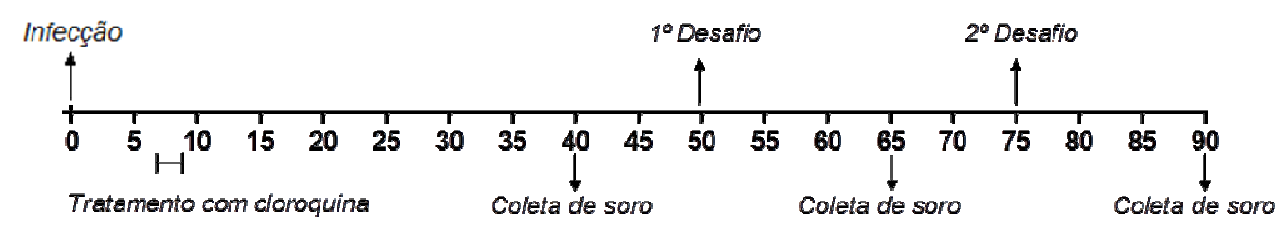

B

Dias após a infecção

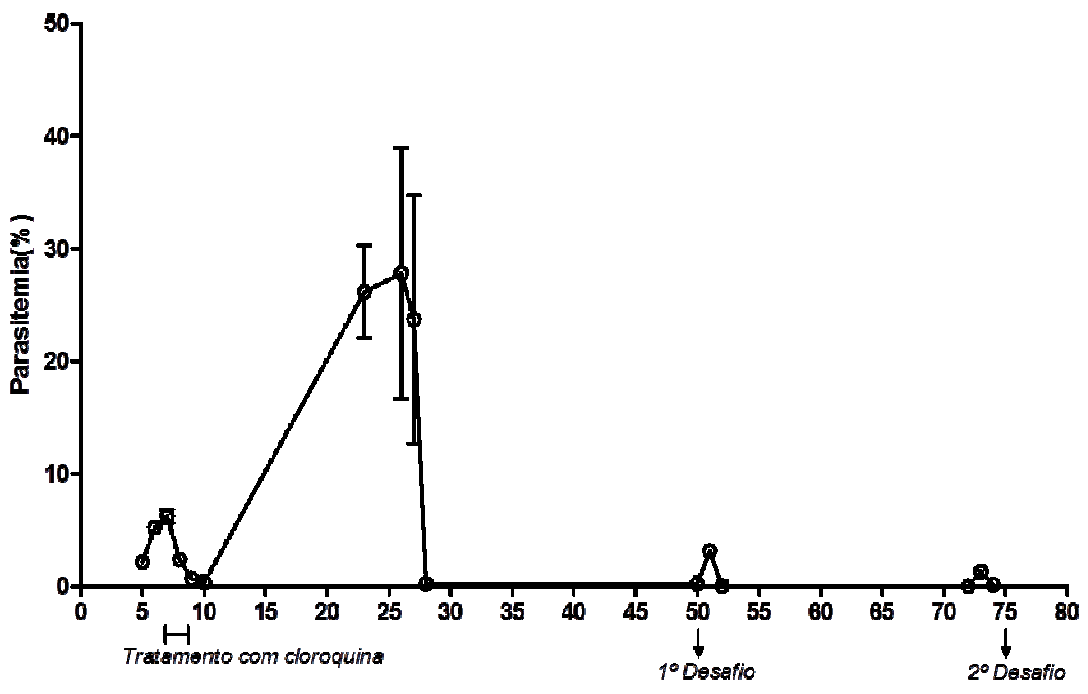

C
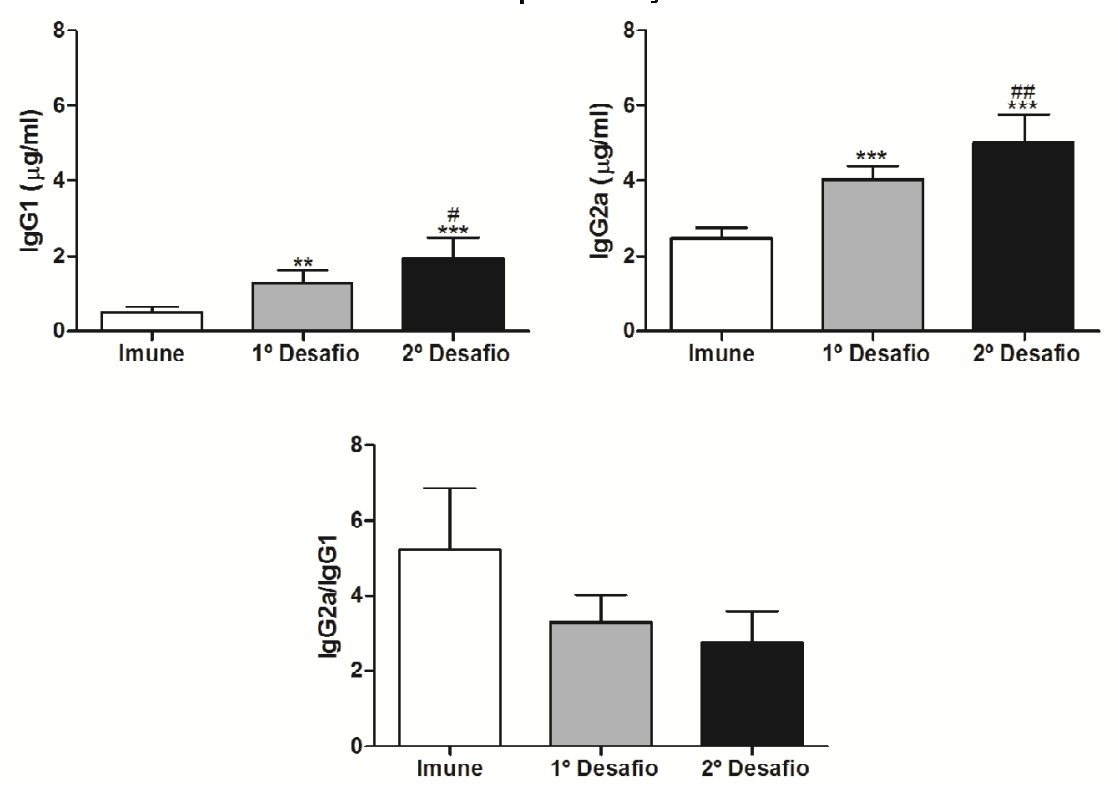

(A) Protocolo experimental do desafio. (B) Curva de parasitemia representativa de fêmeas BALB/C infectadas com $10^{4}$ EP com $P$. berghei ANKA ${ }^{\text {GFP }}$ (D0) e tratadas com cloroquina por 3 dias $\left(0,7 \mathrm{mg} /\right.$ dia/animal) com início no D7. No D50 de infecção as fêmeas foram desafiadas com $10^{4} \mathrm{EP}$ com P. berghei ANKA ${ }^{\text {GFP }}$ e o $2^{\circ}$ desafio ocorreu no D75 com o mesmo inóculo do parasita. (C) Isotipos de IgG anti- $P$. berghei em amostras de soro de fêmeas imunes, coletadas após 14 dias do $2^{\circ}$ pico de infecção, de fêmeas, após 14 dias do $1^{\circ}$ desafio e de fêmeas, após 14 dias do $2^{\circ}$ desafio. Dados expressos como Média $\pm S E\left({ }^{*} p<0,01\right.$ em relação ao imune; ${ }^{* \star *} p<0,001$ em relação ao imune; $\# p<0,05$ em relação ao $1^{\circ}$ desafio; \#\#p $<0,01$ em relação ao $1^{\circ}$ desafio). Número de animais em cada grupo igual a 7. 
Neste trabalho verificamos que fêmeas infectadas e tratadas não apresentam mais parasitas na circulação periférica, sugerindo que estes animais controlam a infecção. No entanto, ao engravidarem, parte das fêmeas apresenta recrudescência, evidenciada com o reaparecimento do parasita na circulação periférica (Fig. 19).

\section{Figura 19. Recrudescência da malária durante a gestação}

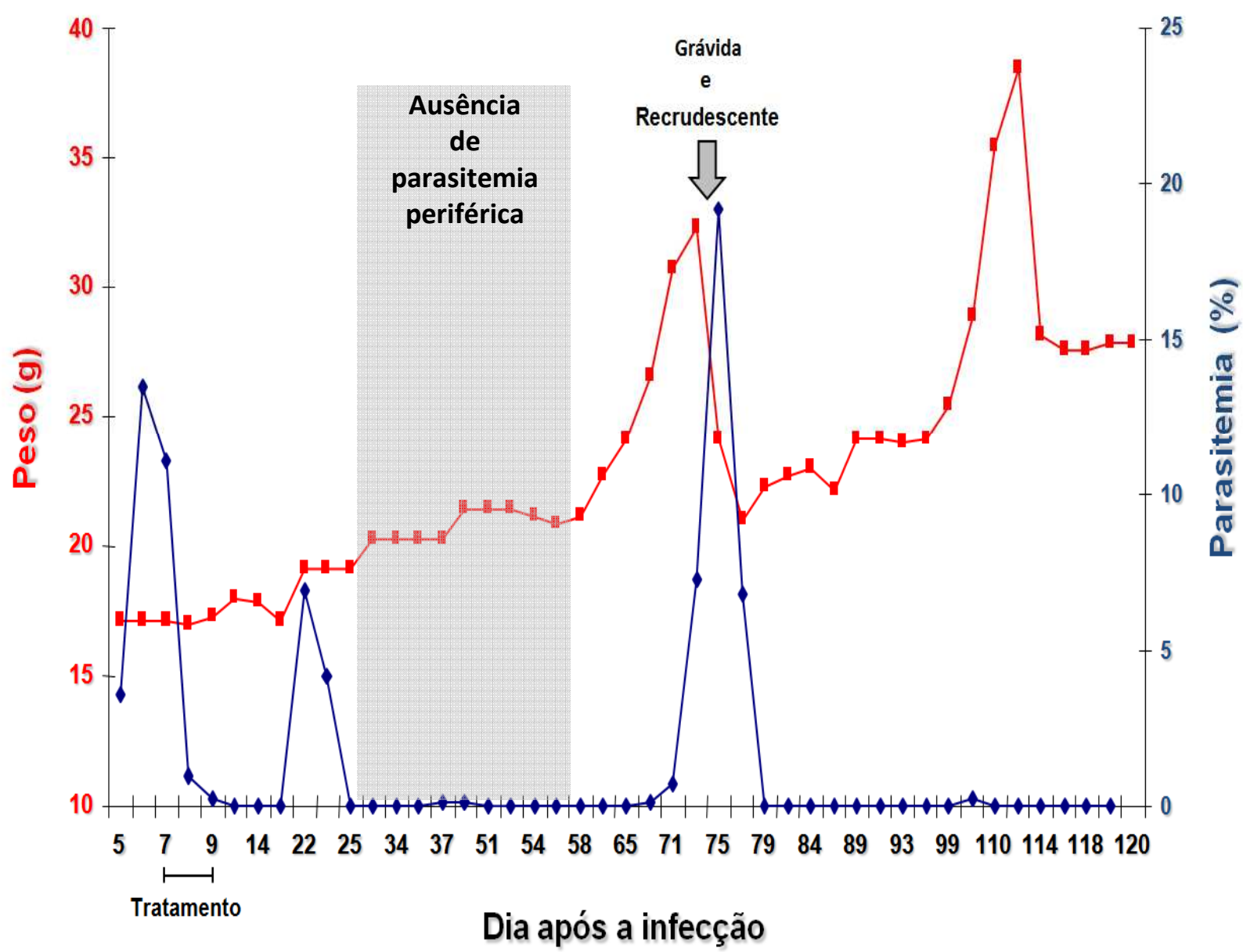

A linha vermelha mostra o aumento de peso confirmando a gravidez e a linha azul o perfil parasitêmico, com aumento de parasitemia durante a gravidez, confirmando a recrudescência. $O$ retângulo cinza indica o período onde não há detecção de parasitemia periférica, que antecede a gravidez. 
Para identificar o local de alojamento dos parasitas durante o período de latência da infecção (antes da gravidez), iniciamos estudos para identificar sua localização. Inicialmente, fizemos a análise por qRT-PCR para identificação do parasita em vários tecidos dos animais, para tanto, utilizamos a técnica descrita em Materiais e Métodos (GONCALVES et al., 2007). Nossos resultados mostram que dos 7 animais analisados, 3 foram positivos para $P$. berghei (Tab. 2). Dentre estes 3 animais, observamos que há maior expressão do gene do parasita $(P$. berghei $18 S$ rRNA) foi no pulmão seguido do baço e fígado (Fig. 20).

Como houve expressão da subunidade $18 \mathrm{~S}$ do RNA ribossomal de $P$. berghei no baço e já que este órgão tem grande importância durante a infecção, por se tratar de um centro de destruição de eritrócitos infectados, realizamos esplenectomia em 10 animais a fim de se identificar a relação deste órgão com a recrudescência. A figura 21 mostra que os animais que tiveram seus baços retirados não recrudesceram, enquanto que os animais controles, não esplectomizados, apresentam uma taxa de $40 \%$ de recrudescência. Além disso, ao verificarmos os picos de parasitemia depois da infecção, observamos que não existia correlação entre estes e a recrudescência (Tab. 3).

Recentemente, foi demonstrado que $P$. berghei consegue se manter viável no interior de células dendríticas (WYKES et al., 2011). Como nosso resultado anterior mostrou que havia uma grande amplificação do sinal no pulmão e no baço, nosso próximo passo foi fazer uma marcação para células dendríticas nestes órgãos. Para isso, as células destes órgãos foram extraídas e marcadas com anticorpo anti-I $A^{b}$ (MHC II), CD3, CD19 e CD11c. Primeiramente, foram selecionadas células duplo negativas para CD3 e CD19, para excluir as células T e B. Em seguida, foi selecionada uma população $I^{\mathrm{b}^{+}}$e por fim, uma população de células $C D 11 c^{+}$. Dentro destas células (CD3-CD19-I $\mathrm{A}^{\mathrm{b}^{+}} \mathrm{CD} 11 \mathrm{C}^{+}$) observamos a presença do GFP, que é um importante indicativo de viabilidade do parasita. Como mostrado na tabela 4 , $40 \%$ das células dendríticas são positivas para GFP no baço (15 animais analisados) e no pulmão (10 animais analisados). No baço, a frequência dessas células é em média $7 \%$, enquanto que no pulmão é 16\% (Fig. 22). 
Tabela 2- Presença de $\boldsymbol{P}$. berghei em diferentes tecidos

\begin{tabular}{ccccccc}
\hline & $\begin{array}{c}\text { Tecido } \\
\text { Adiposo }^{(\mathbf{b})}\end{array}$ & $\operatorname{Rim}^{(\mathbf{b})}$ & Cérebro $^{(\mathbf{b})}$ & Pulmão $^{(\mathbf{b})}$ & Baço $^{(\mathbf{b})}$ & Fígado $^{(\mathbf{b})}$ \\
\hline Animal $^{(\mathbf{a})}$ & $+^{(\mathbf{c})}$ & + & - & + & + & + \\
1 & - & - & - & - & - & - \\
2 & + & + & - & + & + & + \\
3 & - & - & - & - & - & - \\
4 & - & - & - & - & - & - \\
5 & - & - & - & + & - & - \\
7 & - & - & - & - & - & -
\end{tabular}

\footnotetext{
(a) Animais infectados i.p. com $10^{4}$ EP e tratados com cloroquina (0,7mg/dia/animal) durante 3 dias a partir do $7^{\circ}$ dia após infecção.

(b) RNA de órgãos retirados, macerados em nitrogênio e processados.

(c) Indicação da presença do parasita no órgão mencionado.
}

\section{Figura 20: Quantificação da carga parasitária por PCR em tempo real em diferentes tecidos}

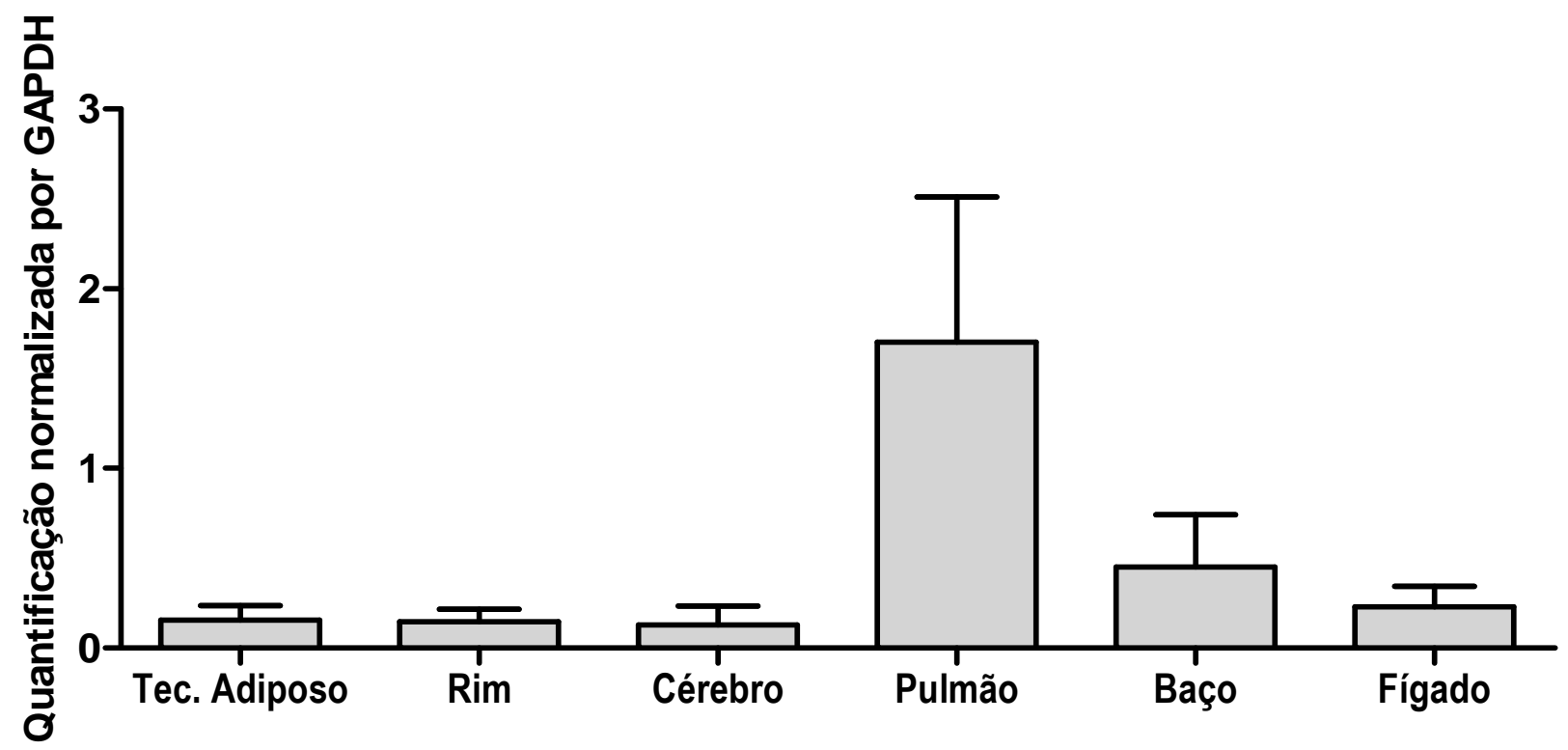

Expressão relativa do gene P.berghei 18S rRNA em fêmeas infectadas. (A) Tabela representativa indicando quais tecidos foram positivos. (B) A expressão foi normalizada pelo GAPDH e quantificada utilizando-se o método $2^{-\Delta C T}$. Dados expressos como Média $\pm S E$. Os dados são representativos de três experiências independentes com duplicatas para cada condição. 
Figura 21. Representação esquemática da esplenectomia

\section{Esplenectomizado}
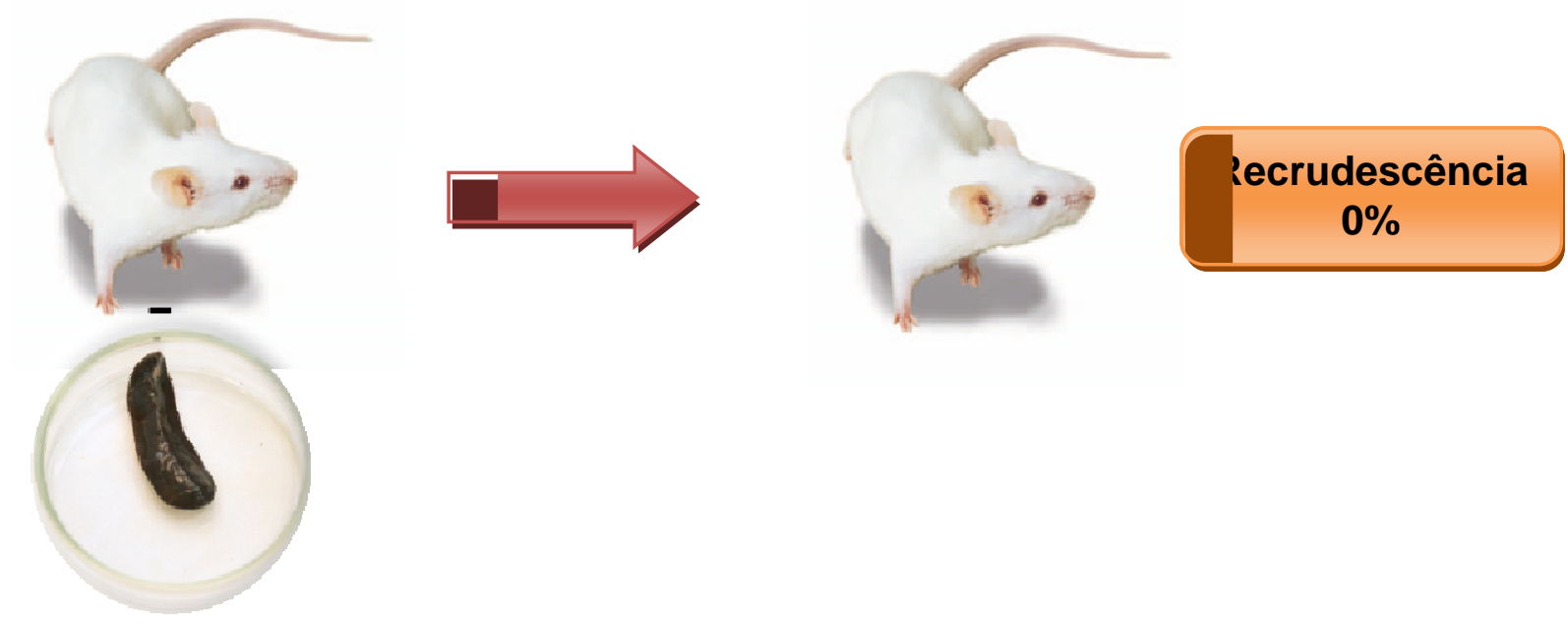

\section{Não-esplenectomizado}
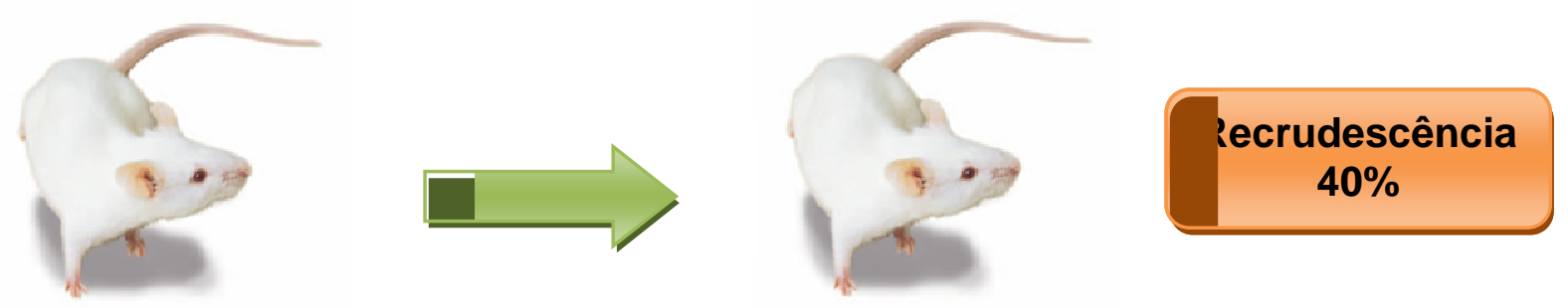

Foram retirados os baços dos animais para identificação da recrudescência. Em animais cujo baço foi retirado, não houve recrudescência, já os não cirurgiados, houve cerca de $40 \%$ de recrudescência. 
Tabela 3- Picos de parasitemia periférica e sua relação com a recrudescência

\begin{tabular}{|c|c|c|c|}
\hline & $\begin{array}{l}1^{\circ} \text { pico } \\
\text { parasitemia }(\%)^{(\mathbf{b})}\end{array}$ & $\begin{array}{l}2^{\circ} \text { pico } \\
\text { parasitemia(\%) }\end{array}$ & Recrudescência $^{(\mathrm{d})}$ \\
\hline \multicolumn{4}{|c|}{ Animal $^{(\mathrm{a})}$} \\
\hline 1 & 7,36 & 1,88 & ND \\
\hline 2 & 6,29 & 6,88 & ND \\
\hline 3 & 6,27 & 5,38 & ND \\
\hline 4 & 10,1 & 4,00 & ND \\
\hline 5 & 6,97 & 7,79 & ND \\
\hline 6 & 29,9 & 37,0 & ND \\
\hline 7 & 21,48 & 3,85 & ND \\
\hline 8 & 30,40 & 59,40 & ND \\
\hline 9 & 12,58 & 68,08 & ND \\
\hline 10 & 6,51 & 6,84 & ND \\
\hline 11 & 50,8 & 64,7 & $\mathrm{D}$ \\
\hline 12 & 6,96 & 18,90 & D \\
\hline 13 & 7,82 & 7,28 & ND \\
\hline 14 & 11,42 & 4,22 & ND \\
\hline 15 & 44,70 & 53,39 & ND \\
\hline
\end{tabular}

(a) Animais infectados i.p. com $10^{4}$ EP e tratados com cloroquina $(0,7 \mathrm{mg} / \mathrm{dia} / \mathrm{animal})$ durante 3 dias a partir do $7^{\circ}$ dia após infecção que foram submetidos a esplenectomia (1 a 10) e seus respectivos controles não esplenectomizados (11 a 15).

(b) Parasitemia quantificada por citometria de fluxo sete dias após a infecção.

(c) Parasitemia quantificada por citometria de fluxo catorze dias após o tratamento.

(d) Recrudescência detectada (D) ou não detectada (ND). 
Figura 22. Localização do $P$. berghei em células dendríticas de baço e pulmão Baço
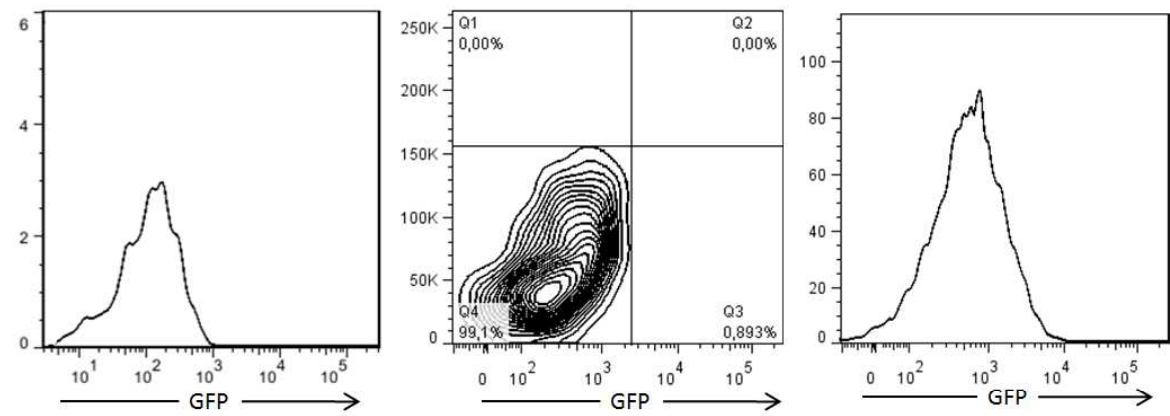

Pulmão
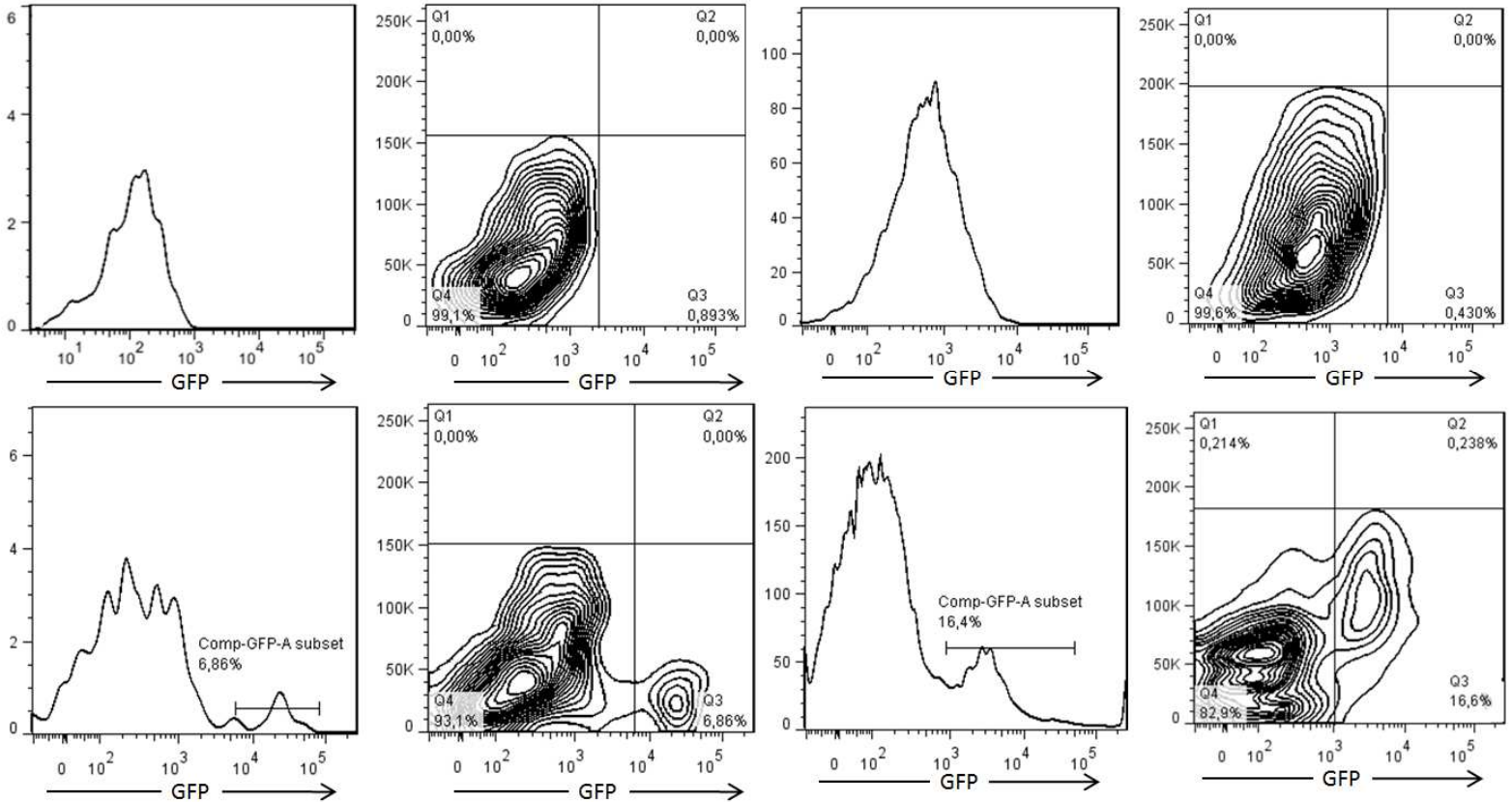

Células do baço e do pulmão de fêmeas não grávidas foram marcadas com diferentes anticorpos (anti CD3, CD19, IA $\mathrm{A}^{\mathrm{b}}, \mathrm{CD} 11 \mathrm{c}$ ) com a finalidade de determinar a localização do plasmódio GFP ${ }^{+}$(ver materiais e métodos). Histograma representativo de células dendríticas do baço e do pulmão, positivas ou não para GFP .

\section{Tabela 4- Presença do parasita em células dendríticas do baço e pulmão}

\begin{tabular}{ccc}
\hline & Baço $^{(\mathrm{b})}$ & Pulmão $^{(\mathrm{b})}$ \\
\hline Animal $^{(\mathrm{a})}$ & - & \\
1 & - & $\mathrm{N} / \mathrm{A}^{(\mathrm{c})}$ \\
2 & - & $\mathrm{N} / \mathrm{A}$ \\
3 & + & $\mathrm{N} / \mathrm{A}$ \\
4 & + & $\mathrm{N} / \mathrm{A}$ \\
5 & + & $\mathrm{N} / \mathrm{A}$ \\
6 & - & $\mathrm{N} / \mathrm{A}$ \\
7 & + & $\mathrm{N} / \mathrm{A}$ \\
8 & - & $\mathrm{N} / \mathrm{A}$ \\
9 & - & $\mathrm{N} / \mathrm{A}$ \\
10 & - & + \\
11 & + & - \\
12 & - & + \\
12 & - & - \\
14 & + & + \\
15 & $\mathrm{+}$ & - \\
16 & $\mathrm{~N} / \mathrm{A}$ & - \\
17 & $\mathrm{~N} / \mathrm{A}$ & + \\
18 & $\mathrm{~N} / \mathrm{A}$ & - \\
19 & $\mathrm{~N} / \mathrm{A}$ & - \\
20 & $\mathrm{~N} / \mathrm{A}$ & \\
\hline
\end{tabular}

(a) Animais infectados i.p. com $10^{4}$ EP e tratados com cloroquina $(0,7 \mathrm{mg} / \mathrm{dia} / \mathrm{animal})$ durante 3 dias a partir do $7^{\circ}$ dia após infecção.

(b) Células extraídas destes órgãos foram marcadas com anticorpos anti CD3, CD19, la ${ }^{\mathrm{b}}$ e CD11c.

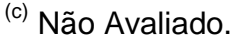


Por fim, as células dendríticas foram selecionadas e enriquecidas por citometria de fluxo como descrito em material e métodos e mostrado na figura 23A. Além das células dendríticas, também selecionamos os macrófagos, população $\mathrm{F} 4 / 80^{+}$, visto que estas células são importantes no controle da infecção, por ter como função a fagocitose. Os resultados apresentados na figura 23B mostram que não existem células positivas para GFP dentro da população de macrófagos, enquanto que entre a população de células dendríticas observa-se uma frequência de $10 \%$ de células GFP positivas. Para evidenciar se as células dendríticas teriam um perfil mais pró-inflamatório ou não, estas células $\left(\mathrm{CD} 11 \mathrm{c}^{+}\right)$foram marcadas com anticorpo anti-CD8. $O$ resultado mostrado na figura $23 \mathrm{C}$ indica que as células positivas para GFP expressam o marcador $\mathrm{CD} \mathrm{a}^{+}$e portanto são pró-inflamatórias. 
Figura 23. Separação de células para localização do plasmódio

A
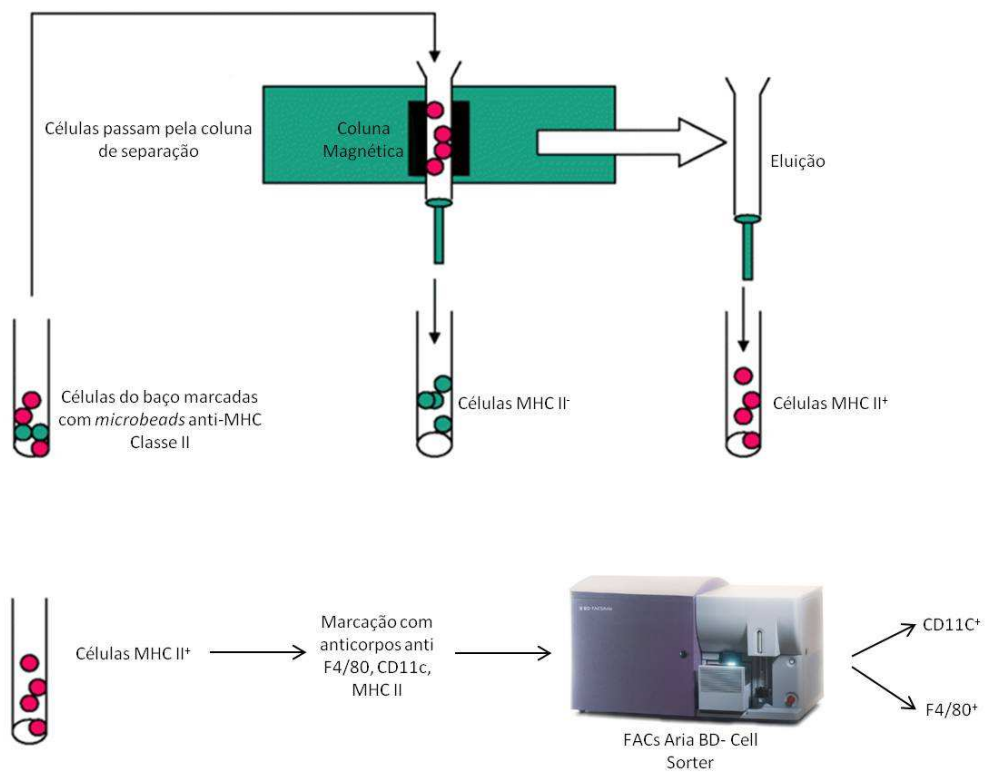

B
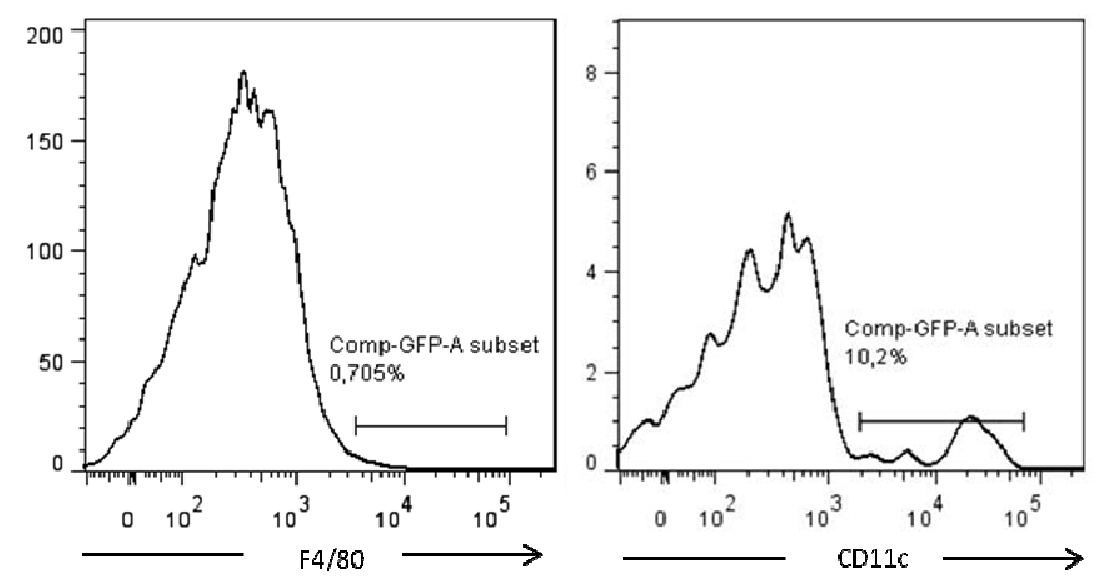

C
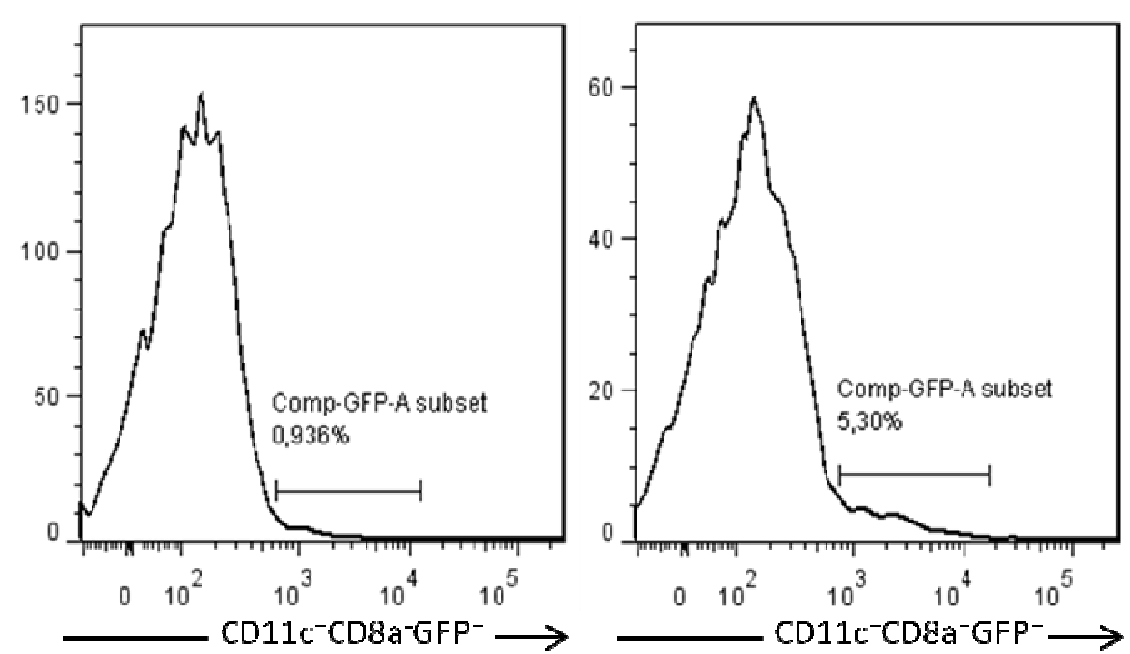

Os esplenócitos foram marcados com microbeads anti MHC classe II para separação. (A) Células marcadas foram separadas por meio de coluna magnética, marcadas com diferentes anticorpos e submetidas à separação por meio de um citômetro de fluxo. (ver materiais e métodos). (B) Verificação da presença do $P$. berghei ANKA ${ }^{\text {GFP }}$ em células dendríticas $\left(\right.$ CD11c ${ }^{+}$). (C) Células CD11c ${ }^{+}$marcadas com anti-CD8. 
Têm se demonstrado que mulheres que vivem em áreas onde a transmissão da doença é estável podem apresentar imunidade clínica às infecções por Plasmodium falciparum (NOSTEN et al., 2004). Entretanto, os mais severos sintomas da doença acontecem no período gestacional, principalmente, na primeira e na segunda gravidez, sugerindo a existência de um forte mecanismo de proteção associado à imunidade específica frente àqueles parasitas sequestrados na placenta. Nestes casos, o aumento dos níveis de parasitemia durante a gestação é um importante indicador de susceptibilidade (BRABIN et al., 2004). Entretanto, os mecanismos responsáveis pela recrudescência da infecção durante a gravidez ainda são pouco compreendidos.

Neste sentido, reproduzimos parcialmente o modelo de recrudescência descrito anteriormente pelo nosso grupo, com camundongos BALB/c infectados por Plasmodium berghei ANKA ${ }^{\text {GFP }}$. Este modelo de pré-exposição em que as fêmeas são imunizadas antes da gestação reproduz algumas das observações epidemiológicas da malária associada à gravidez que ocorrem em mulheres que vivem em regiões onde a transmissão é instável. Nestas regiões os baixos níveis de imunidade específica frente ao plasmódio podem trazer sérios riscos tanto para mãe, quanto para o feto em desenvolvimento. Entretanto, uma imunidade específica contra as formas placentárias do parasita é adquirida após sucessivas gestações, podendo prevenir o sequestro e, dessa maneira, evitar a cascata de eventos inflamatórios que conduzem ao agravamento da doença. Estudos envolvendo a recrudescência da malária em populações humanas apresentam uma série de limitações, principalmente dificuldade de se diferenciar recrudescência de uma nova infecção. Assim acreditamos que esta associação parasita-hospedeiro pode ser útil na compreensão dos mecanismos que levam ao aumento do risco de recrudescência da malária induzida pela gestação (MARINHO et al., 2009).

Diferente do que foi descrito anteriormente, neste trabalho a infecção de fêmeas BALB/c por $P$. berghei ANKA GFP utilizando inóculo $10^{6} \mathrm{EP}$ apresentou níveis muito altos de mortalidade e por isso mostrou-se inviável para a continuidade dos nossos estudos. Os melhores resultados com relação à mortalidade e parasitemia foram obtidos com a utilização do inóculo de $10^{4} \mathrm{EP}$, dessa forma optamos por dar continuidade às análises utilizando este inóculo. 
Uma possível explicação para estas diferenças poderia estar relacionada com padrões de ativação do sistema imunológico distintos numa mesma linhagem de camundongos mantida em diferentes biotérios. Trabalhos recentes tem demonstrado diferenças marcantes na microbiota intestinal em linhagens geneticamente idênticas de camundongos de diferentes fornecedores. Denning e colaboradores observaram que células dendríticas de camundongos C57BL/6 provenientes do laboratório Jackson são mais eficientes em induzir Treg Foxp3 ${ }^{+}$e menos eficientes em induzir resposta por Th17 que aqueles da mesma linhagem, porém do Laboratório da Charles River (DENNING et al., 2011). Assim a simples presença de uma espécie de bactéria filamentosa segmentada presente nos animais do Laboratório da Charles River foi capaz de induzir a expansão das populações de células T produtoras de IL17 (Th17), indicando que a composição da microbiota intestinal é determinante para regulação do balanço TH17/Treg.

Esses dados sugerem que as diferenças que nós observamos em relação ao inóculo quando comparadas com o trabalho anteriormente publicado (MARINHO et al., 2009) podem estar associadas a padrões distintos de regulação do sistema imune decorrentes da microbiota dos animais, já que estes provêm de biotérios diferentes.

A placenta representa a interface entre $o$ sangue materno $e \mathrm{o}$ fetal $\mathrm{e}$ desempenha um papel crucial no estudo da malária associada à gravidez, visto que o plasmódio pode se acumular no tecido placentário durante a gestação. Em infecções por $P$. falciparum este órgão pode apresentar um nível elevado de parasitas, hemozoína, infiltrado celular constituído principalmente de monócitos, juntamente com uma maior expressão de citocinas pró-inflamatórias e quimiocinas, além de alterações morfológicas como o espessamento do sinciciotrofoblasto (ISMAIL et al., 2000). Esta alteração diminui o espaço vascular e consequentemente a área disponível para trocas gasosas e de nutrientes resultando em riscos para os fetos (BRABIN et al., 2004).

Assim, as placentas de animais não infectados e infectados com recrudescência ou não foram submetidas a uma análise morfométrica para a quantificação da área vascular. Esta é uma avaliação indireta do espessamento do sinciciotrofoblasto, ou seja, quanto menor a área vascular quantificada, maior será o espessamento deste. Nossos resultados mostram uma significativa diminuição desta 
área em animais recrudescentes que provavelmente é devido a uma resposta inflamatória local contra o parasita (NERES et al., 2008) e sua intensidade será determinante na evolução da gestação.

De forma interessante identificamos que fêmeas não recrudescentes apresentam uma diminuição significativa da área vascular quando comparadas com controles não infectadas, o que nos sugere uma disfunção placentária mesmo com ausência de parasitemia periférica. Este fato reforça a hipótese de que os mecanismos efetores do sistema imune não são suficientemente eficientes no controle do parasitismo tissular, corroborando com a hipótese que o parasita desempenha um papel central neste tipo de patologia. Estes achados têm importantes implicações para a prevenção da malária placentária, reforçando a necessidade de quimioterapia na fase inicial da infecção.

O próximo passo foi verificar quais alterações no "status" imunológico estariam envolvidas com a recrudescência. Para isso fizemos um estudo do baço e da placenta. O primeiro por se tratar de um importante centro de destruição de eritrócitos infectados e o segundo por ser um órgão vital para a gestação e que apresenta receptores como o CSA (Condroitina Sulfato A) que é expresso em altas concentrações na placenta humana e que está diretamente envolvido no sequestro de eritrócitos parasitados (HVIID et al., 2010). Foi observado que o baço de um animal recrudescente apresenta maior quantidade de células quando comparado com animal controle não infectado e animal recrudescente. Isto se deve ao aumento de leucócitos que ocorre comumente em resposta a infecções (CRUZ CUBAS et al., 1993).

A análise do número absoluto das populações do baço mostra um aumento significativo de linfócitos $\mathrm{TCD}^{+}$, de células $\mathrm{B}, \mathrm{TCR} \gamma \delta^{+}$e $\mathrm{F} 4 / 80^{+}$nos animais com recrudescência comparadas ao controle. No entanto, quando se correlaciona com carga parasitária, há um aumento de células $\mathrm{TCD}^{+}$em fêmeas com baixa parasitemia e aumento de granulócitos $\left(\mathrm{GR} 1^{+}\right)$em fêmeas com alta parasitemia quando comparadas com controle não infectado. Além disso, há uma diminuição significante de linfócitos TCD4 ${ }^{+}$entre os grupos recrudescentes, evidenciando que a carga parasitária na fase aguda da infecção pode interferir na modulação do sistema imune posteriormente. 
Em nossos resultados vimos um aumento significativo de células TCR $\gamma \delta$ nas fêmeas recrudescentes. Estas células estão envolvidas na resposta a muitos microorganismos e em diversos processos fisiopatológicos, podendo ativar e matar através de moléculas efetoras e pela liberação de moléculas citotóxicas, como perforina e granzima. Também estão diretamente ligadas ao recrutamento de outras células como macrófagos e neutrófilos, além de exercer papel no sistema imune adaptativo (BONNEVILLE et al., 2010). Devido a sua interação com macrófagos, acredita-se que elas possuam um papel protetor frente ao Plasmodium (LANGHORNE, 1996). Já foi demonstrado que estas células estão relacionadas à remoção do parasita e na inibição do crescimento do mesmo, em experimentos in vitro e in vivo (ELLOSO et al., 1994, TSUJl et al., 1994). Analisando hemácias do cordão umbilical infectadas por $P$. falciparum, o grupo de Engelmann mostrou que as células TCR $\gamma \delta$ são importantes no controle do parasita na interface útero/cordão umbilical e se mantém ativadas ao longo do período do desenvolvimento fetal (ENGELMANN et al., 2005).

Vimos também um aumento de granulócitos, utilizando marcador GR1, em fêmeas recrudescentes. Estes são requeridos durante uma infecção por Plasmodium devido a sua capacidade de fagocitose e destruição de eritrócitos infectados por vias dependentes de espécies reativas de oxigênio e intermediários de nitrogênio (KUMARATILAKE et al., 1997). Porém podem ser um componente importante na malária grave, pela sua capacidade de produzir altos níveis de citocinas, como TNF$\alpha$ durante a resposta inflamatória (CHEN et al., 2000).

Células NK (do inglês Natural Killer) estão diretamente ligadas à lise de células-alvo e expressão de citocinas, assim ativando as células apresentadoras de antígenos e direcionando a células T a um padrão Th1 (SCOTT e TRINCHIERI, 1995). Na malária, estão relacionadas com o controle da replicação do parasita na fase precoce, devido a sua ação de lise e por ser fonte de citocinas próinflamatórias, principalmente IFN- $\gamma$, mediando à resposta por macrófagos, além do controle da imunidade adquirida (HANSEN et al., 2007). Nossos resultados mostram uma tendência ao aumento de células NK em fêmeas recrudescentes sugerindo um indício da ação efetora das mesmas durante a recrudescência.

De acordo com os parâmetros imunológicos avaliados, células do baço de fêmeas recrudescentes estão mais ativadas do que aquelas provenientes de não 
recrudescentes e de controle. Observou-se que tanto células TCD4 ${ }^{+}$quanto TCD8 ${ }^{+}$ apresentam-se como a população com maior expressão de CD69 e menor expressão de CD62L (L-selectina). Esta molécula é um importante marcador de 'homing' direcionando células T naive para entrada em órgãos linfóides secundários. Por outro lado, células $T$ efetoras ou de memória não expressam ou possuem baixa expressão de L-selectina (NICHOLSON, 2002). Estes dados indicam que 0 compartimento de células $T$ efetoras e/ou de memória é ativado significativamente na gestação com o recrudescimento da infecção.

Embora macrófagos esplênicos expressem naturalmente baixos níveis de CD86 em relação a outras populações de macrófagos tissulares (LIU et al., 2006) é interessante notar que os animais infectados recrudescentes ou não tiveram uma significativa diminuição na expressão deste marcador. Alguns estudos com $P$. falciparum têm sugerido que um potencial mecanismo envolvido na diminuição da resposta mediada por células $T$ poderia ser a diminuição da expressão de MHC classe II e proteínas co-estimulatórias pelas células apresentadoras de antígenos (URBAN et al., 1999). Schwarzer e colaboradores mostraram que a hemozoína interfere no aumento da expressão de moléculas como MHC classe II. Este mecanismo assegura o desenvolvimento de células $T$ helper e é determinante para 0 resultado da doença e infecções secundárias. A falta de expressão de MHC classe II pode explicar defeitos na ativação das células $T$ e alteração na resposta imune célula T dependente (SCHWARZER et al., 1998, URBAN et al., 1999). Além disso, estudos feitos com pigmento malárico sintético mostra que o mesmo desencadeia estresse oxidativo, que por sua vez, induz a depressão de funções de fagócitos (TARAMELLI et al., 2000).

Em relação à placenta, vimos uma diminuição no número absoluto de células nos grupos infectados quando comparados com o controle, sugerindo uma inibição de proliferação celular em decorrência de alterações hormonais causadas pela infecção por Plasmodium (REZENDE FILHO e MONTENEGRO, 2011). Estudos anteriores demonstram que o aumento de hormônios corticosteróides como o cortisol, durante a infecção malárica, em recrudescentes, induz imunossupressão e diminui a capacidade de proliferação celular (VAN ZON et al., 1982). Altas concentrações de cortisol reduzem a capacidade citotóxica de células NK, o número de linfócitos no baço e no timo, além da resposta dos anticorpos. Estes efeitos se 
devem à ligação dos corticosteróides aos receptores específicos presentes nos leucócitos, causando modulação direta da transcrição de genes responsáveis pela replicação celular ou agindo de forma indireta, interferindo na síntese de citocinas envolvidas no processo de proliferação (BOUYOU-AKOTET et al., 2005, HEFFNER, 2010).

Em adição, Sharma e colaboradores mostraram que células do infiltrado inflamatório e eritrócitos infectados na placenta induzem um aumento na produção de espécies reativas de oxigênio, devido a um sistema antioxidante deficiente. Assim o aumento do estresse oxidativo, correlacionado com o aumento da parasitemia, ativa a via mitocondrial de apoptose, levando ao dano tecidual e por consequência a uma diminuição do número total de células (SHARMA et al., 2012).

Não foram observadas diferenças significativas entre as populações estudadas na placenta, mesmo quando se analisa a carga parasitária, entretanto há uma tendência à diminuição de macrófagos, marcados com anticorpo anti-F4/80 em fêmeas recrudescentes, corroborando com o resultado visto no baço. Em relação à ativação, houve uma tendência ao aumento de leucócitos ativados em fêmeas recrudescentes. Além disso, houve um aumento significativo de células TCD4 ${ }^{+}$ ativadas nas fêmeas recrudescentes quando comparadas com não recrudescentes $\mathrm{e}$ controle não infectado, sugerindo um papel importante de células $T$ durante a infecção placentária.

Diversas citocinas estão envolvidas na patogênese da malária, no entanto a que desempenha um papel central é o TNF- $\alpha$ (Fator de Necrose Tumoral), que participa da ativação dos mecanismos anti-parasitários de leucócitos efetores. A fonte primária de secreção desta citocina são os monócitos e macrófagos, ativados por produtos do parasita e está correlacionada com os episódios de febre da doença (PERLMANN e TROYE-BLOMBERG, 2002).

A malária placentária está associada com altos níveis de TNF- $\alpha$ correlacionado com o aumento de infiltrado inflamatório na placenta (BRABIN et al., 2004). Esta citocina está envolvida no retardo do crescimento intra-uterino, pois diminui a passagem transplacentária de aminoácidos, compostos essenciais para o acréscimo de proteínas e oxidação no metabolismo fetal (CARBO et al., 1995). Além disso, pode levar a nascimentos prematuros, ocorrência de natimortos e anemia 
materna, que ocorre devido a inibição da eritropoiese pela supressão da formação de células eritróides (FRIED et al., 1998).

Nós observamos um aumento das concentrações de TNF- $\alpha$ em fêmeas com recrudescimento da infecção. Além disso, quando comparamos animais com alta e baixa parasitemia, observamos uma tendência ao aumento desta citocina em fêmeas com alta parasitemia, o que indica que a carga parasitária é um importante componente na regulação dos níveis da mesma.

Além de TNF- $\alpha$, observamos um aumento de outras citocinas próinflamatórias como IL-6 e IFN- $\gamma$ em fêmeas recrudescentes. Estas citocinas são importantes no controle da infecção, entretanto podem levar a perda gestacional além de ocasionar parto prematuro (NETA et al., 2010). Em adição, Kabyemela e colaboradores mostraram que a malária placentária aumenta os níveis de citocinas inflamatórias na placenta e que IFN- $\gamma$ está associado com baixo peso ao nascer (KABYEMELA et al., 2008).

Citocinas anti-inflamatórias como IL-10 parecem ter um papel crucial na regulação e proteção durante a infecção por plasmódio, sendo antagonista da função citolítica e diminuindo a resposta Th1 (BRABIN et al., 2004). Além disso, a presença de IL-10 é capaz de inibir a produção de quimiocinas, como IL-8, reduzindo desta forma, o recrutamento de neutrófilos para o sítio de infecção (ZEYREK et al., 2006). Estudos demonstram que a baixa frequência nos níveis de IL-10 estão relacionados com o aumento da mortalidade (BUENO et al., 2010). Em nossos resultados, observamos um aumento significativo de IL-10 em fêmeas não recrudescentes, que corrobora com os resultados obtidos por Sarr e colaboradores, onde foi demonstrado que infecções crônicas durante a malária placentária, evidenciadas por pequenas quantidades de hemozoína na placenta, induzem aumento dos níveis de IL-10 (SARR et al., 2010).

Malária placentária, causada por P. falciparum, está relacionada com o acúmulo de eritrócitos infectados na placenta. Este acúmulo, conhecido como sequestro, baseia-se na adesão do parasita ao receptor CSA, presente em grandes quantidades nesse órgão (FRIED et al., 1998). Primigrávidas não possuem imunidade ao parasita que se liga ao CSA, devido à falta de anticorpos que bloqueiam essa adesão. Por esse motivo, são mais suscetíveis, sendo que a 
proteção se desenvolve ao longo de sucessivas gestações (ROGERSON et al., 2007).

Em nosso modelo experimental, os camundongos são pré-expostos ao parasita e desenvolvem uma intensa resposta imune, observada por um pico transiente de parasitemia que evolui para uma cura aparente. Nossos resultados mostram altos títulos de anticorpos lgG em fêmeas imunes, sugerindo que a infecção residual suporta uma contínua resposta humoral anti-parasita, contribuindo para um estado de proteção a longo prazo contra malária. Além disso, vimos que fêmeas recrudescentes possuem maiores níveis de IgG quando comparadas com não recrudescentes, o que nos indica que a presença do $P$. berghei é capaz de provocar e manter a estimulação antigênica durante a gravidez, principalmente quando ocorre a recrudescência. Em adição, observamos um aumento de IgG2a em relação a lgG1 sugerindo um padrão de resposta Th1, estimulada por citocinas como IFN- $\gamma$. Os altos níveis de IgG2a (corresponde a IgG3 em humanos) identificados no nosso modelo corrobora com algumas observações provenientes de áreas endêmicas do continente africano.

Em regiões de alta transmissão, a imunidade adquirida para $P$. falciparum depende de repetidas exposições ao parasita, sendo que a idade tem sido considerada como indicativo do grau de exposição (OLIVEIRA-FERREIRA et al., 2010). Esta imunidade está associada com diferentes classes de anticorpos, principalmente as subclasses lgG1 e lgG3 que estão relacionadas com proteção ao desenvolvimento de sintomas e diminuição da carga parasitária. Estes anticorpos atuam promovendo a opsonização do eritrócito infectado, ativando a via clássica do sistema complemento ou mediando a citotoxicidade celular dependente de anticorpos, via interação com os receptores Fc da superfície de fagócitos (STANISIC et al., 2009).

Nosso modelo parte de uma única infecção seguida de um tratamento subcurativo com cloroquina. Desta forma para simular as regiões de alta endemicidade e verificar se a recrudescência está correlacionada com repetidas exposições ao parasita, reproduzimos esta situação, re-infectando os animais por duas vezes. Nossos resultados indicam que após o desafio há um aumento dos títulos de anticorpos IgG, com predominância da subclasse lgG2a (equivalente a lgG3 em humanos). Além disso, houve diminuição da parasitemia periférica na $1^{\underline{a}}$ e $2^{\underline{a}}$ re- 
infecção, sugerindo que a presença destes anticorpos confere proteção. Com o aumento da exposição ao parasita e da imunidade específica, observamos que as fêmeas grávidas não recrudesceram. Esses dados abrem a possibilidade que a recrudescência esteja correlacionada com uma ineficiente imunidade humoral e que esta pode ser otimizada de forma qualitativa e quantitativa com sucessivos desafios.

Situações de recaída após vários anos podem ser observadas em indivíduos infectados por $P$. vivax e $P$. ovale, neste caso, devido a presença de hipnozoítos no fígado (ANSTEY et al., 2009). Além disso, o P. falciparum também pode persistir após a infecção inicial e sem parasitemia periférica aparente (PINELI et al., 1999), sugerindo que outras células, que não os hepatócitos, podem abrigar os eritrócitos parasitados, evitando assim que estes sejam eliminados pelo sistema imune.

O sequestro de eritrócitos infectados por Plasmodium na microvasculatura de órgãos é associado como uma importante causa da patologia. Esta característica facilita a multiplicação do parasita, evitando ainda sua destruição no baço. Como consequência, ocorre o dano tecidual devido à obstrução vascular, ativação do endotélio e o aumento local de citocinas pró-inflamatórias (SHERMAN et al., 2003). Em infecções por $P$. falciparum, o principal receptor que está amplamente distribuído em células endoteliais é o CD36 (receptor scavenger do tipo II) que além do envolvimento na citoaderência, participa da modulação das repostas inata e adquirida (HO e WHITE, 1999).

Utilizando a técnica qRT-PCR, observamos um grande aumento da expressão de RNA do parasita no pulmão, seguido do baço. Fayard-Franke e colaboradores mostraram que a presença de esquizontes no pulmão é mediada por CD36, principal receptor celular envolvido no sequestro do parasita neste órgão. Além disso, os mesmos autores observaram quantidades significativas de esquizontes no baço (FRANKE-FAYARD et al., 2005). Estudos com modelos murinos indicam que durante a malária placentária, o parasita $P$. berghei está presente tanto no pulmão, quanto no baço (HVIID et al., 2010).

Visto que houve expressão do gene $P$. berghei $18 \mathrm{~S}$ rRNA no baço, e que este órgão é importante no controle da infecção, devido a sua capacidade de destruição de eritrócitos parasitados, realizamos esplenectomia para verificar se a ocorrência de recrudescência estava relacionada com a presença ou não deste órgão. De forma interessante, observamos que os animais que tiveram seus baços retirados, 
não recrudesceram, independentemente dos picos de parasitemia durante a infecção aguda. Estes dados levantaram a hipótese que o baço poderia ser um importante reservatório de parasitas e necessitávamos investigar se estes parasitas poderiam estar associados há uma determinada população leucocitária.

Células dendríticas são células apresentadoras de antígenos e desempenham um papel central, promovendo a ligação da imunidade inata e adaptativa (STEVENSON e RILEY, 2004). Eritrócitos parasitados por $P$. falciparum se ligam as dendríticas através de CD36, mediando sua função, e inibindo a maturação destas células (ELLIOTT et al., 2007). Repostas humoral T-dependente são induzidas durante a malária aguda, sendo que as pessoas que vivem em áreas endêmicas, frequentemente apresentam altos níveis de IgG. A resposta imune pode ser modulada pelo parasita, sendo que na presença deste, células dendríticas secretam IL-10 e induzem a um padrão de resposta Th2, interferindo na indução de células de memória (URBAN et al., 2001).

Recentemente, Wykes e colaboradores, utilizando ensaios in vitro, mostraram que $P$. berghei pode sobreviver e se replicar em células dendríticas e que uma pequena porcentagem destas células liberam parasitas capazes de infectar novos eritrócitos de camundongos (WYKES et al., 2011).

Vimos anteriormente por qRT-PCR a presença de RNA de $P$. berghei em órgãos como pulmão e baço. Observamos também que células dendríticas presentes nestes órgãos abriga o parasita transgênico, evidenciado pela presença de GFP nos ensaios de citometria de fluxo. A expressão desta proteína só ocorre em parasitas viáveis, já que quando há morte, eles deixam de expressá-la (FRANKEFAYARD et al., 2004).

Para estabelecer o perfil das possíveis sub-populações de células dendríticas que poderiam funcionar como reservatório, utilizamos o marcador CD8a. Células

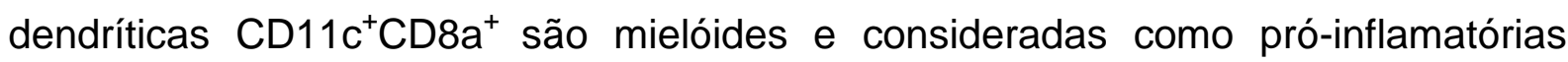
(STEVENSON et al., 2011). Stevenson e colaboradores demonstraram que durante infecção por bactéria, células dendríticas dos linfonodos e pulmões são responsáveis pela indução de um padrão de resposta Th1, promovendo proteção. Estas células estão ativadas, expressam MHC classe II, moléculas co-estimulatórias e secretam citocinas como IFN- $\gamma$ e IL-10 (DUNNE et al., 2009). Por outro lado, Fujimoto e colaboradores mostraram que células $\mathrm{CD} 11 \mathrm{c}^{+} \mathrm{CD} 8 \mathrm{a}^{-}$, apesar de também produzirem 
citocinas pró-inflamatórias, desempenham um papel regulador, visto que podem induzir células $T$ reguladoras Foxp3 ${ }^{+}$na presença de TGF- $\beta$ (FUJIMOTO et al., 2011).

Wykes e colaboradores observaram que as células dendríticas que funcionam como reservatório do plasmódio são $\mathrm{CD} 317^{+}$, um marcador de células inflamatórias. Além disso, não foi vista a presença do parasita em macrófagos, marcados com anticorpo anti-F4/80. Nossos resultados mostram pela primeira vez in vivo, que as células dendríticas que apresentam o fenótipo inflamatório $C D 11 c^{+} C D 8 a^{+}$são capazes de abrigar o $P$. berghei. Por outro lado não identificamos parasitas em macrófagos, fato evidenciado pela ausência de marcação para GFP em células $\mathrm{F} 4 / 80^{+}$. Uma possível explicação para ausência de parasitas associados a macrófagos seria alta capacidade de atividade microbicida, como produção de $\mathrm{NO}$ e $\mathrm{H}_{2} \mathrm{O}_{2}$ obsevada nestas células.

Em conjunto, nossos dados demonstram que no final do período de gestação, as placentas de camundongos recrudescentes passam por um forte processo inflamatório, evidenciado pela presença de células ativadas, aumento de citocinas pró-inflamatórias e a presença de grandes quantidades de anticorpos IgG2a. Além disso, acreditamos que em nosso modelo as células dendríticas inflamatórias podem funcionar como um possível reservatório do parasita, entretanto desconhecemos os mecanismos envolvidos na sobrevivência e manutenção destes parasitas dentro destas células. Este estudo abre uma importante perspectiva, no sentido de que a patologia placentária pode ser reduzida, utilizando-se para este fim, protocolos terapêuticos que controlem os níveis de parasitemia na fase aguda da infecção. 
Os resultados obtidos nesse trabalho trazem contribuições para o entendimento dos mecanismos envolvidos na recrudescência da malária placentária. Dessa forma, as principais conclusões obtidas foram:

- A utilização de camundongos BALB/c infectados com $10^{4} \mathrm{EP}$ com Plasmodium berghei ANKA ${ }^{\text {GFP }}$ via i.p. foi considerada mais adequada para o estudo da recrudescência;

- A recrudescência leva a uma diminuição da área do espaço interviloso na placenta, podendo levar ao decremento da sua função;

- As fêmeas recrudescentes quando comparadas com as não recrudescentes e controle apresentam um perfil aumentado de ativação do sistema imunológico caracterizado por linfócitos ativados, presença de citocinas pró-inflamatórias e aumento dos níveis de lgG2a;

- A presença de altos títulos de anticorpos específicos induzidos pelo desafio reduz a recrudescência, e por esse motivo, uma vacina capaz de modular a resposta humoral, parece ser promissora;

- Algumas evidências indicam que células dendríticas são neste modelo o reservatório natural do parasita. 
ALEXANDRE, M. A.; FERREIRA, C. O.; SIQUEIRA, A. M.; MAGALHAES, B. L.; MOURAO, M. P.; LACERDA, M. V.; ALECRIM, M. G. Severe Plasmodium vivax malaria, Brazilian Amazon. Emerg. Infect. Dis., v. 16, p. 1611-1614, 2010.

ANSTEY, N. M.; RUSSELL, B.; YEO, T. W.; PRICE, R. N. The pathophysiology of vivax malaria. Trends Parasitol., v. 25, p. 220-227, 2009.

ARIBODOR, D. N.; NWAORGU, O. C.; ENEANYA, C. I.; OKOLI, I.; PUKKILAWORLEY, R.; ETAGA, H. O. Association of low birth weight and placental malarial infection in Nigeria. J. Infect. Dev. Ctries, v. 3, p. 620-623, 2009.

AVRAMEAS, S.; HOSLI, P.; STANISLAWSKI, M.; RODRIGOT, M.; VOGT, E. A quantitative study at the single cell level of immunoglobulin antigenic determinants present on the surface of murine $B$ and $T$ lymphocytes. $\mathbf{J}$. Immunol., v. 122, p. 648-659, 1979.

BARILLAS-MURY, C.; KUMAR, S. Plasmodium-mosquito interactions: a tale of dangerous liaisons. Cell Microbiol., v. 7, p. 1539-1545, 2005.

BONNEVILLE, M.; O'BRIEN, R. L.; BORN, W. K. Gammadelta T cell effector functions: a blend of innate programming and acquired plasticity. Nat., v. 10, p. 467-478, 2010.

BORRMANN, S.; MATUSCHEWSKI, K. Protective immunity against malaria by 'natural immunization': a question of dose, parasite diversity, or both? Curr. Opin. Immunol., v. 23, p. 500-508, 2011.

BOUYOU-AKOTET, M. K.; ADEGNIKA, A. A.; AGNANDJI, S. T.; NGOUMILAMA, E.; KOMBILA, M.; KREMSNER, P. G.; MAVOUNGOU, E. Cortisol and susceptibility to malaria during pregnancy. Microbes Infect., v. 7, p. 1217-1223., 2005.

BRABIN, B. J.; ROMAGOSA, C.; ABDELGALIL, S.; MENENDEZ, C.; VERHOEFF, F. H.; MCGREADY, R.; FLETCHER, K. A.; OWENS, S.; D'ALESSANDRO, U.; NOSTEN, F.; FISCHER, P. R.; ORDI, J. The sick placenta-the role of malaria. Placenta, v. 25, p. 359-378., 2004.

BUENO, L. L.; MORAIS, C. G.; ARAUJO, F. F.; GOMES, J. A.; CORREAOLIVEIRA, R.; SOARES, I. S.; LACERDA, M. V.; FUJIWARA, R. T.; BRAGA, E. M. Plasmodium vivax: induction of CD4+CD25+FoxP3+ regulatory T cells during infection are directly associated with level of circulating parasites. PLoS One, v. 5, p. e9623, 2010.

CARBO, N.; LOPEZ-SORIANO, F. J.; ARGILES, J. M. Administration of tumor necrosis factor-alpha results in a decreased placental transfer of amino acids in the rat. Endocrinol., v. 136, p. 3579-3584, 1995.

CARVALHO, B. O.; LOPES, S. C.; NOGUEIRA, P. A.; ORLANDI, P. P.; BARGIERI, D. Y.; BLANCO, Y. C.; MAMONI, R.; LEITE, J. A.; RODRIGUES, M. M.; SOARES, I. S.; OLIVEIRA, T. R.; WUNDERLICH, G.; LACERDA, M.

De acordo com:

ASSOCIAÇÃO BRASILEIRA DE NORMAS

TÉCNICAS. NBR 6023: informação e 
V.; DEL PORTILLO, H. A.; ARAUJO, M. O.; RUSSELL, B.; SUWANARUSK, R.; SNOUNOU, G.; RENIA, L.; COSTA, F. T. On the cytoadhesion of Plasmodium vivax-infected erythrocytes. J. Infect. Dis., v. 202, p. 638-647, 2010.

CHAGAS, E. C. D. S.; NASCIMENTO, C. T. D.; SANTANA FILHO, F. S. E. D.; BÃ'TTO-MENEZES, C. H.; MARTINEZ-ESPINOSA, F. E. Malária durante a gravidez: efeito sobre o curso da gestação na região amazônica. Rev. Pan. de Saúde Pública, v. 26, p. 203-208, 2009.

CHEN, L.; ZHANG, Z.; SENDO, F. Neutrophils play a critical role in the pathogenesis of experimental cerebral malaria. Clin. Exp. Immunol., v. 120, p. 125-133., 2000.

CLYDE, D. F. Immunity to falciparum and vivax malaria induced by irradiated sporozoites: a review of the University of Maryland studies, 1971-75. Bull. World Health Organ., v. 68 Suppl, p. 9-12, 1990.

COX, F. E. History of the discovery of the malaria parasites and their vectors. Parasit. Vectors, v. 3, p. 5, 2010.

CROMPTON, P. D.; PIERCE, S. K.; MILLER, L. H. Advances and challenges in malaria vaccine development. J. Clin. Invest., v. 120, p. 4168-4178, 2010.

CRUZ CUBAS, A. B.; BALLET, J. J.; GENTILINI, M.; MONJOUR, L. [Cellmediated immunity and protection against blood stages of Plasmodium falciparum]. Presse Med., v. 22, p. 1967-1973, 1993.

CUMMING, G.; FIDLER, F.; VAUX, D. L. Error bars in experimental biology. J. Cell. Biol., v. 177, p. 7-11, 2007.

DAWES, B. Advances in parasitology. London, New York: Academic Press, 1988.

DELLICOUR, S.; TATEM, A. J.; GUERRA, C. A.; SNOW, R. W.; TER KUILE, F. O. Quantifying the number of pregnancies at risk of malaria in 2007: a demographic study. PLoS, v. 7, p. e1000221, 2010.

DENNING, T. L.; NORRIS, B. A.; MEDINA-CONTRERAS, O.; MANICASSAMY, S.; GEEM, D.; MADAN, R.; KARP, C. L.; PULENDRAN, B. Functional specializations of intestinal dendritic cell and macrophage subsets that control Th17 and regulatory $\mathrm{T}$ cell responses are dependent on the $\mathrm{T}$ cell/APC ratio, source of mouse strain, and regional localization. J. Immunol., v. 187, p. $733-747,2011$.

DESAI, M.; TER KUILE, F. O.; NOSTEN, F.; MCGREADY, R.; ASAMOA, K.; BRABIN, B.; NEWMAN, R. D. Epidemiology and burden of malaria in pregnancy. Lancet Infect. Dis., v. 7, p. 93-104, 2007. 
DUNNE, P. J.; MORAN, B.; CUMMINS, R. C.; MILLS, K. H. CD11C+CD8alpha+ dendritic cells promote protective immunity to respiratory infection with Bordetella pertussis. J. Immunol., v. 183, p. 400-410, 2009.

ELLIOTT, S. R.; SPURCK, T. P.; DODIN, J. M.; MAIER, A. G.; VOSS, T. S.; YOSAATMADJA, F.; PAYNE, P. D.; MCFADDEN, G. I.; COWMAN, A. F.; ROGERSON, S. J.; SCHOFIELD, L.; BROWN, G. V. Inhibition of dendritic cell maturation by malaria is dose dependent and does not require Plasmodium falciparum erythrocyte membrane protein 1 . Infect Immun, v. 75, p. 36213632, 2007.

ELLOSO, M. M.; VAN DER HEYDE, H. C.; VANDE WAA, J. A.; MANNING, D. D.; WEIDANZ, W. P. Inhibition of Plasmodium falciparum in vitro by human gamma delta T cells. J. Immunol., v. 153, p. 1187-1194, 1994.

ENGELMANN, I.; SANTAMARIA, A.; KREMSNER, P. G.; LUTY, A. J. Activation status of cord blood gamma delta $T$ cells reflects in utero exposure to Plasmodium falciparum antigen. J. Infect. Dis., v. 191, p. 1612-1622, 2005.

FEACHEM, R. G. A.; PHILLIPS, A. A.; HWANG, J.; COTTER, C.; WIELGOSZ, B.; GREENWOOD, B. M.; SABOT, O.; RODRIGUEZ, M. H.; ABEYASINGHE, R. R.; GHEBREYESUS, T. A.; SNOW, R. W. Shrinking the malaria map: progress and prospects. The Lancet, v. 376, p. 1566-1578, 2010.

FERREIRA, M. U.; KIMURA, E. A.; DE SOUZA, J. M.; KATZIN, A. M. The isotype composition and avidity of naturally acquired anti-Plasmodium falciparum antibodies: differential patterns in clinically immune Africans and Amazonian patients. Am. J. Trop. Med. Hyg., v. 55, p. 315-323, 1996.

FRANKE-FAYARD, B.; TRUEMAN, H.; RAMESAR, J.; MENDOZA, J.; VAN DER KEUR, M.; VAN DER LINDEN, R.; SINDEN, R. E.; WATERS, A. P.; JANSE, C. J. A Plasmodium berghei reference line that constitutively expresses GFP at a high level throughout the complete life cycle. Mol. Biochem. Parasitol., v. 137, p. 23-33, 2004.

FRANKE-FAYARD, B.; JANSE, C. J.; CUNHA-RODRIGUES, M.; RAMESAR, J.; BUSCHER, P.; QUE, I.; LOWIK, C.; VOSHOL, P. J.; DEN BOER, M. A.; VAN DUINEN, S. G.; FEBBRAIO, M.; MOTA, M. M.; WATERS, A. P. Murine malaria parasite sequestration: CD36 is the major receptor, but cerebral pathology is unlinked to sequestration. Proc. Natl. Acad. Sci. U S A, v. 102, p. 11468-11473, 2005.

FRIED, M.; DUFFY, P. E. Adherence of Plasmodium falciparum to chondroitin sulfate $A$ in the human placenta. Science, v. 272, p. 1502-1504, 1996.

FRIED, M.; MUGA, R. O.; MISORE, A. O.; DUFFY, P. E. Malaria elicits type 1 cytokines in the human placenta: IFN-gamma and TNF-alpha associated with pregnancy outcomes. J. Immunol., v. 160, p. 2523-2530, 1998.

FRIED, M.; NOSTEN, F.; BROCKMAN, A.; BRABIN, B. J.; DUFFY, P. E. Maternal antibodies block malaria. Nature, v. 395, p. 851-852, 1998. 
FUJIMOTO, K.; KARUPPUCHAMY, T.; TAKEMURA, N.; SHIMOHIGOSHI, M.; MACHIDA, T.; HASEDA, Y.; AOSHI, T.; ISHII, K. J.; AKIRA, S.; UEMATSU, S. A new subset of CD103+CD8alpha+ dendritic cells in the small intestine expresses TLR3, TLR7, and TLR9 and induces Th1 response and CTL activity. J. Immunol., v. 186, p. 6287-6295, 2011.

GAMAIN, B.; GRATEPANCHE, S.; MILLER, L. H.; BARUCH, D. I. Molecular basis for the dichotomy in Plasmodium falciparum adhesion to CD36 and chondroitin sulfate A. Proc. Natl. Acad. Sci. U S A, v. 99, p. 10020-10024, 2002.

GARCIA, C. R.; MARKUS, R. P.; MADEIRA, L. Tertian and quartan fevers: temporal regulation in malarial infection. J. Biol. Rhythms., v. 16, p. 436-443, 2001.

GOEL, S.; GOWDA, D. C. How specific is Plasmodium falciparum adherence to chondroitin 4-sulfate? Trends Parasitol., v. 27, p. 375-381, 2011.

GONCALVES, L. A.; VIGARIO, A. M.; PENHA-GONCALVES, C. Improved isolation of murine hepatocytes for in vitro malaria liver stage studies. Malar. J., v. 6, p. 169, 2007.

GRAVES, P.; GELBAND, H. Vaccines for preventing malaria (preerythrocytic). Cochrane Database Syst. Rev., v. p. CD006198, 2006.

GREENWOOD, B. M.; FIDOCK, D. A.; KYLE, D. E.; KAPPE, S. H.; ALONSO, P. L.; COLLINS, F. H.; DUFFY, P. E. Malaria: progress, perils, and prospects for eradication. J. Clin. Invest., v. 118, p. 1266-1276, 2008.

HAFALLA, J. C.; SILVIE, O.; MATUSCHEWSKI, K. Cell biology and immunology of malaria. Immunol. Reviews, v. 240, p. 297-316, 2011.

HANSEN, D. S.; D'OMBRAIN, M. C.; SCHOFIELD, L. The role of leukocytes bearing Natural Killer Complex receptors and Killer Immunoglobulin-like Receptors in the immunology of malaria. Curr. Opin. Immunol., v. 19, p. 416423, 2007.

HEFFNER, K. L. Neuroendocrine effects of stress on immunity in the elderly: implications for inflammatory disease. Immunol. Allergy Clin. North Am., v. 31, p. 95-108, 2010.

HERRERA, S.; CORRADIN, G.; AREVALO-HERRERA, M. An update on the search for a Plasmodium vivax vaccine. Trends Parasitol., v. 23, p. 122-128, 2007.

HO, M.; WHITE, N. J. Molecular mechanisms of cytoadherence in malaria. Am. J. Physiol., v. 276, p. C1231-1242, 1999.

HULDEN, L. Activation of the hypnozoite: a part of Plasmodium vivax life cycle and survival. Malar. J., v. 10, p. 90, 2011. 
HVIID, L.; MARINHO, C. R.; STAALSOE, T.; PENHA-GONCALVES, C. Of mice and women: rodent models of placental malaria. Trends Parasitol., v. 26, p. 412-419, 2010.

HVIID, L.; MARINHO, C. R.; STAALSOE, T.; PENHA-GONCALVES, C. Of mice and women: rodent models of placental malaria. Trends Parasitol, v. 26, p. 412-419, 2010.

ISMAIL, M. R.; ORDI, J.; MENENDEZ, C.; VENTURA, P. J.; APONTE, J. J.; KAHIGWA, E.; HIRT, R.; CARDESA, A.; ALONSO, P. L. Placental pathology in malaria: a histological, immunohistochemical, and quantitative study. Hum. Pathol., v. 31, p. 85-93, 2000.

KABYEMELA, E. R.; FRIED, M.; KURTIS, J. D.; MUTABINGWA, T. K.; DUFFY, P. E. Fetal responses during placental malaria modify the risk of low birth weight. Infect. Immun., v. 76, p. 1527-1534, 2008.

KALILANI, L.; MOFOLO, I.; CHAPONDA, M.; ROGERSON, S. J.; MESHNICK, $S$. R. The effect of timing and frequency of Plasmodium falciparum infection during pregnancy on the risk of low birth weight and maternal anemia. Trans., v. 104, p. $416-422,2010$.

KIRCHGATTER, K.; DEL PORTILLO, H. A. Clinical and molecular aspects of severe malaria. Anais da Acad. Brasil. de Ciências, v. 77, p. 455-475, 2005.

KUMARATILAKE, L. M.; FERRANTE, A.; ROBINSON, B. S.; JAEGER, T.; POULOS, A. Enhancement of neutrophil-mediated killing of Plasmodium falciparum asexual blood forms by fatty acids: importance of fatty acid structure. Infect. Immun., v. 65, p. 4152-4157, 1997.

KYES, S. A.; KRAEMER, S. M.; SMITH, J. D. Antigenic variation in Plasmodium falciparum: gene organization and regulation of the var multigene family. Eukaryot. Cell, v. 6, p. 1511-1520, 2007.

LANGHORNE, J. gammadelta T cells in malaria infections. Parasitol. Today, v. 12 , p. 200-203, 1996.

LAZAROU, M.; GUEVARA PATINO, J. A.; JENNINGS, R. M.; MCINTOSH, R. S.; SHI, J.; HOWELL, S.; CULLEN, E.; JONES, T.; ADAME-GALLEGOS, J. R.; CHAPPEL, J. A.; MCBRIDE, J. S.; BLACKMAN, M. J.; HOLDER, A. A.; PLEASS, R. J. Inhibition of erythrocyte invasion and Plasmodium falciparum merozoite surface protein 1 processing by human immunoglobulin G1 (IgG1) and IgG3 antibodies. Infect. Immun., v. 77, p. 5659-5667, 2009.

LIU, G.; XIA, X. P.; GONG, S. L.; ZHAO, Y. The macrophage heterogeneity: difference between mouse peritoneal exudate and splenic $\mathrm{F} 4 / 80_{+}$ macrophages. J. Cell Physiol., v. 209, p. 341-352, 2006.

LUCCHI, N. W.; PETERSON, D. S.; MOORE, J. M. Immunologic activation of human syncytiotrophoblast by Plasmodium falciparum. Malar. J., v. 7, p. 42, 2008. 
LUNDIE, R. J. Antigen presentation in immunity to murine malaria. Curr. Opin. Immunol., v. 23, p. 119-123, 2011.

LUXEMBURGER, C.; RICCI, F.; NOSTEN, F.; RAIMOND, D.; BATHET, S.; WHITE, N. J. The epidemiology of severe malaria in an area of low transmission in Thailand. Trans. R. Soc. Trop. Med. Hyg., v. 91, p. 256-262, 1997.

MARINHO, C. R.; NERES, R.; EPIPHANIO, S.; GONCALVES, L. A.; CATARINO, M. B.; PENHA-GONCALVES, C. Recrudescent Plasmodium berghei from pregnant mice displays enhanced binding to the placenta and induces protection in multigravida. PLoS One, v. 4, p. e5630, 2009.

MAYOR, A.; SERRA-CASAS, E.; BARDAJI, A.; SANZ, S.; PUYOL, L.; CISTERO, P.; SIGAUQUE, B.; MANDOMANDO, I.; APONTE, J. J.; ALONSO, P. L.; MENENDEZ, C. Sub-microscopic infections and long-term recrudescence of Plasmodium falciparum in Mozambican pregnant women. Malar. J., v. 8, p. 9, 2009.

MCGREGOR, I. A. Epidemiology, malaria and pregnancy. Am. J. Trop. Med. Hyg., v. 33, p. 517-525, 1984.

MEGNEKOU, R.; HVIID, L.; STAALSOE, T. Variant-specific immunity to Plasmodium berghei in pregnant mice. Infect. Immun., v. 77, p. 1827-1834, 2009.

MENDIS, K. N.; CARTER, R. The role of cytokines in Plasmodium vivax malaria. Mem. Inst. Oswaldo Cruz, v. 87 Suppl 3, p. 51-55, 1992.

MENENDEZ, C. Malaria during pregnancy: a priority area of malaria research and control. Parasitol. Today, v. 11, p. 178-183, 1995.

MILLER, L. H.; BARUCH, D. I.; MARSH, K.; DOUMBO, O. K. The pathogenic basis of malaria. Nat., v. 415, p. 673-679, 2002.

MINISTÉRIO DA SAÚDE, S. D. V. E. S. Guia prático de tratamento da malária no Brasil. Minist. da Saúde, v. p. 2010.

MUEHLENBACHS, A.; FRIED, M.; MCGREADY, R.; HARRINGTON, W. E.; MUTABINGWA, T. K.; NOSTEN, F.; DUFFY, P. E. A novel histological grading scheme for placental malaria applied in areas of high and low malaria transmission. J. Infect. Dis., v. 202, p. 1608-1616, 2010.

NAYAK, K. C.; KHATRI, M. P.; GUPTA, B. K.; SIROHI, P.; CHOUDHARY, V.; VERMA, S. K.; BENIWAL, S. Spectrum of vivax malaria in pregnancy and its outcome: a hospital-based study. J. Vector Borne Dis., v. 46, p. 299-302, 2009.

NERES, R.; MARINHO, C. R.; GONCALVES, L. A.; CATARINO, M. B.; PENHA-GONCALVES, C. Pregnancy outcome and placenta pathology in 
Plasmodium berghei ANKA infected mice reproduce the pathogenesis of severe malaria in pregnant women. PLoS One, v. 3, p. e1608, 2008.

NETA, G. I.; VON EHRENSTEIN, O. S.; GOLDMAN, L. R.; LUM, K.; SUNDARAM, R.; ANDREWS, W.; ZHANG, J. Umbilical cord serum cytokine levels and risks of small-for-gestational-age and preterm birth. Am. J. Epidemiol., v. 171, p. 859-867, 2010.

NICHOLSON, I. C. CD62L (L-selectin). J. Biol. Regul. Homeost. Agents, v. 16, p. 144-146, 2002.

NOSTEN, F.; MCGREADY, R.; SIMPSON, J. A.; THWAI, K. L.; BALKAN, S.; CHO, T.; HKIRIJAROEN, L.; LOOAREESUWAN, S.; WHITE, N. J. Effects of Plasmodium vivax malaria in pregnancy. Lancet., v. 354, p. 546-549., 1999.

NOSTEN, F.; ROGERSON, S. J.; BEESON, J. G.; MCGREADY, R.; MUTABINGWA, T. K.; BRABIN, B. Malaria in pregnancy and the endemicity spectrum: what can we learn? Trends Parasitol., v. 20, p. 425-432, 2004.

NUSSENZWEIG, R. S.; VANDERBERG, J.; MOST, H.; ORTON, C. Protective immunity produced by the injection of $\mathrm{X}$-irradiated sporozoites of plasmodium berghei. Nat., v. 216, p. 160-162, 1967.

OLIVEIRA-FERREIRA, J.; LACERDA, M. V.; BRASIL, P.; LADISLAU, J. L.; TAUIL, P. L.; DANIEL-RIBEIRO, C. T. Malaria in Brazil: an overview. Malar. J., v. 9, p. 115, 2010.

PERLMANN, P.; TROYE-BLOMBERG, M. Malaria and the immune system in humans. Chem. Immunol., v. 80, p. 229-242, 2002.

PICHYANGKUL, S.; GETTAYACAMIN, M.; MILLER, R. S.; LYON, J. A.; ANGOV, E.; TONGTAWE, P.; RUBLE, D. L.; HEPPNER, D. G., JR.; KESTER, K. E.; BALLOU, W. R.; DIGGS, C. L.; VOSS, G.; COHEN, J. D.; WALSH, D. S. Pre-clinical evaluation of the malaria vaccine candidate $P$. falciparum MSP1(42) formulated with novel adjuvants or with alum. Vaccine, v. 22, p. 3831-3840, 2004.

PINELI, L. L.; SCHOEPFER, A. C. D. A.; JARDIM, D. V.; SANTOS, E. R. D.; ALMEIDA NETTO, J. C. D. Malária por Plasmodium falciparum. Análise quadrienal, durante 12 anos, da eficácia do tratamento com quinino. Rev. da Soc. Brasil. de Med. Tropical, v. 32, p. 241-245, 1999.

POOVASSERY, J.; MOORE, J. M. Association of malaria-induced murine pregnancy failure with robust peripheral and placental cytokine responses. Infect. Immun., v. 77, p. 4998-5006, 2009.

PORTES, M. D. G. T.; ROSSI, J. C. N.; NASCIMENTO, J. C. D.; ZECCER, S.; SILVA, L. A. Anofelinos de Santa Catarina (Diptera: Culicidae), Brasil. Rev. da Soc. Brasil. de Med. Tropical, v. 43, p. 156-160, 2010. 
REED, Z. H.; FRIEDE, M.; KIENY, M. P. Malaria vaccine development: progress and challenges. Curr. Mol. Med., v. 6, p. 231-245, 2006.

REID, T. M. S. Striking a balance in maternal immune response to infection. The Lancet, v. 351, p. 1670-1672, 1998.

REZENDE FILHO, J.; MONTENEGRO, C. Obstetrícia Fundamental. Rio de Janeiro: Guanabara Koogan, 2011. 724 pp

RILEY, E. M.; WAHL, S.; PERKINS, D. J.; SCHOFIELD, L. Regulating immunity to malaria. Parasite Immunol., v. 28, p. 35-49, 2006.

ROETYNCK, S.; BARATIN, M.; VIVIER, E.; UGOLINI, S. NK cells and innate immunity to malaria. Med. Sci., v. 22, p. 739-744, 2006.

ROGERSON, S. J.; BOEUF, P. New approaches to pathogenesis of malaria in pregnancy. Parasitol., v. 134, p. 1883-1893, 2007.

ROGERSON, S. J.; HVIID, L.; DUFFY, P. E.; LEKE, R. F.; TAYLOR, D. W. Malaria in pregnancy: pathogenesis and immunity. Lancet Infect. Dis., v. 7, p. 105-117, 2007.

SACHS, J.; MALANEY, P. The economic and social burden of malaria. Nat., v. 415, p. 680-685, 2002.

SARAIVA, M. D. G. A. G.; AMORIM, R. D. S.; MOURA, M. A. N. S. I.; MARTINEZ-ESPINOSA, F. E.; BARBOSA, M. D. G. A. V. Expansão urbana e distribuição espacial da malária no município de Manaus, Estado do Amazonas. Rev. da Soc. Brasil. de Med. Tropical, v. 42, p. 515-522, 2009.

SARR, D.; ALDEBERT, D.; MARRAMA, L.; FREALLE, E.; GAYE, A.; BRAHIM, H. O.; NIANG, M.; DANGOU, J. M.; MERCEREAU-PUIJALON, O.; LEHESRAN, J. Y.; JAMBOU, R. Chronic infection during placental malaria is associated with up-regulation of cycloxygenase-2. Malar. J., v. 9, p. 45, 2010.

SCHWARZER, E.; ALESSIO, M.; ULLIERS, D.; ARESE, P. Phagocytosis of the malarial pigment, hemozoin, impairs expression of major histocompatibility complex class II antigen, CD54, and CD11C in human monocytes. Infect. Immun., v. 66, p. 1601-1606, 1998.

SCOTT, P.; TRINCHIERI, G. The role of natural killer cells in host-parasite interactions. Curr. Opin. Immunol., v. 7, p. 34-40, 1995.

SHARMA, L.; KAUR, J.; SHUKLA, G. Role of Oxidative Stress and Apoptosis in the Placental Pathology of Plasmodium berghei Infected Mice. PLoS One, v. 7, p. e32694, 2012.

SHERMAN, I. W.; EDA, S.; WINOGRAD, E. Cytoadherence and sequestration in Plasmodium falciparum: defining the ties that bind. Microbes Infect., v. 5, p. 897-909, 2003. 
SMITH, N. C. An immunological hypothesis to explain the enhanced susceptibility to malaria during pregnancy. Parasitol. Today., v. 12, p. 4-6, 1996.

STAALSOE, T.; SHULMAN, C. E.; BULMER, J. N.; KAWUONDO, K.; MARSH, K.; HVIID, L. Variant surface antigen-specific IgG and protection against clinical consequences of pregnancy-associated Plasmodium falciparum malaria. The Lancet, v. 363, p. 283-289, 2004.

STANISIC, D. I.; RICHARDS, J. S.; MCCALLUM, F. J.; MICHON, P.; KING, C. L.; SCHOEPFLIN, S.; GILSON, P. R.; MURPHY, V. J.; ANDERS, R. F.; MUELLER, I.; BEESON, J. G. Immunoglobulin G subclass-specific responses against Plasmodium falciparum merozoite antigens are associated with control of parasitemia and protection from symptomatic illness. Infect. Immun., v. 77, p. 1165-1174, 2009.

STEVENSON, M. M.; RILEY, E. M. Innate immunity to malaria. Nat. Rev. Immunol., v. 4, p. 169-180, 2004.

STEVENSON, M. M.; ING, R.; BERRETTA, F.; MIU, J. Regulating the adaptive immune response to blood-stage malaria: role of dendritic cells and CD4Foxp3 regulatory T cells. Int. J. Biol. Sci., v. 7, p. 1311-1322, 2011.

SULTAN, A. A.; THATHY, V.; FREVERT, U.; ROBSON, K. J.; CRISANTI, A.; NUSSENZWEIG, V.; NUSSENZWEIG, R. S.; MENARD, R. TRAP is necessary for gliding motility and infectivity of plasmodium sporozoites. Cell, v. 90, p. 511-522, 1997.

SUTHERLAND, C. J.; LAUNDY, M.; PRICE, N.; BURKE, M.; FIVELMAN, Q. L.; PASVOL, G.; KLEIN, J. L.; CHIODINI, P. L. Mutations in the Plasmodium falciparum cytochrome $b$ gene are associated with delayed parasite recrudescence in malaria patients treated with atovaquone-proguanil. Malar. J., v. 7, p. 240, 2008.

TARAMELLI, D.; RECALCATI, S.; BASILICO, N.; OLLIARO, P.; CAIRO, G. Macrophage preconditioning with synthetic malaria pigment reduces cytokine production via heme iron-dependent oxidative stress. Lab. Invest., v. 80, p. 1781-1788, 2000.

TRAMPUZ, A.; JEREB, M.; MUZLOVIC, I.; PRABHU, R. M. Clinical review: Severe malaria. Crit. Care, v. 7, p. 315-323, 2003.

TSUJI, M.; MOMBAERTS, P.; LEFRANCOIS, L.; NUSSENZWEIG, R. S.; ZAVALA, F.; TONEGAWA, S. Gamma delta T cells contribute to immunity against the liver stages of malaria in alpha beta T-cell-deficient mice. Proc. Natl. Acad. Sci. U S A, v. 91, p. 345-349, 1994.

TSUTSUI, H.; ADACHI, K.; SEKI, E.; NAKANISHI, K. Cytokine-induced inflammatory liver injuries. Curr. Mol. Med., v. 3, p. 545-559, 2003. 
URBAN, B. C.; FERGUSON, D. J.; PAIN, A.; WILLCOX, N.; PLEBANSKI, M.; AUSTYN, J. M.; ROBERTS, D. J. Plasmodium falciparum-infected erythrocytes modulate the maturation of dendritic cells. Nat., v. 400 , p. 73-77, 1999.

URBAN, B. C.; WILLCOX, N.; ROBERTS, D. J. A role for CD36 in the regulation of dendritic cell function. Proc. Natl. Acad. Sci. U S A, v. 98, p. 8750-8755, 2001.

VAN ZON, A. A.; ELING, W. M. Pregnancy associated recrudescence in murine malaria (Plasmodium berghei). Tropenmed Parasitol., v. 31, p. 402408., 1980.

VAN ZON, A. A.; ELING, W. M.; HERMSEN, C. C.; KOEKKOEK, A. A. Corticosterone regulation of the effector function of malarial immunity during pregnancy. Infect. Immun., v. 36, p. 484-491, 1982.

VAN ZON, A. A.; ELING, W. M.; HERMSEN, C. C. Pregnancy-induced recrudescences strengthen malarial immunity in mice infected with Plasmodium berghei. Parasitol., v. 91, p. 9-17, 1985.

WHO. A strategic framework for malaria prevention and control during pregnancy in the African region. Brazzaville. WHO Regional Office for Africa. Available from: www.cdc.gov/malaria/pdf/strategic_framework_mip_04.pdf, 2004.

WHO. World malaria report 2010. World Health Organization, v. p. 2010.

WHO. World malaria report 2011. World Health Organization, v. p. 2011.

WYKES, M. N.; KAY, J. G.; MANDERSON, A.; LIU, X. Q.; BROWN, D. L.; RICHARD, D. J.; WIPASA, J.; JIANG, S. H.; JONES, M. K.; JANSE, C. J.; WATERS, A. P.; PIERCE, S. K.; MILLER, L. H.; STOW, J. L.; GOOD, M. F. Rodent blood-stage Plasmodium survive in dendritic cells that infect naive mice. Proc. Natl. Acad. Sci. U S A, v. 108, p. 11205-11210, 2011.

YAMAUCHI, L. M.; COPPI, A.; SNOUNOU, G.; SINNIS, P. Plasmodium sporozoites trickle out of the injection site. Cell Microbiol., v. 9, p. 1215-1222, 2007.

ZEYREK, F. Y.; KURCER, M. A.; ZEYREK, D.; SIMSEK, Z. Parasite density and serum cytokine levels in Plasmodium vivax malaria in Turkey. Parasite Immunol., v. 28, p. 201-207, 2006. 